UNIVERSIDADE DE SÃO PAULO

ESCOLA DE ENFERMAGEM

\begin{abstract}
"A CONSTRUÇÃO DA COMPETÊNCIA CLÍNICA: da concepção dos planejamentos de ensino às representações da aprendizagem entre graduandos de Enfermagem"
\end{abstract}

MAGDA CRISTINA QUEIROZ DELL'ACQUA

São Paulo

2004 


\section{"A CONSTRUÇÃO DA COMPETÊNCIA CLÍNICA: da concepção dos planejamentos de ensino às representações da aprendizagem entre graduandos de Enfermagem"}

Tese apresentada à Escola de Enfermagem da Universidade de São Paulo para obtenção do título de Doutor em Enfermagem

Orientadora: $\operatorname{Prof}^{a} \operatorname{Dr}^{\underline{a}}$ Ana Maria Kazue Miyadahira

Co-Orientadora: Prof ${ }^{\underline{a}} \mathrm{Dr}^{\underline{a}}$ Cilene Aparecida Costardi Ide

São Paulo 2004 
Catalogação na publicação (CIP)

Serviço de Biblioteca e Documentação da EEUSP

Dell'acqua, Magda Cristina Queiroz

A construção da competência clínica: da concepção dos planejamentos de ensino às representações da aprendizagem entre graduando de enfermagem / Magda Cristina Queiroz Dell'Acqua. - São Paulo: M. C. Q. Dell'Acqua; 2004.

$188 \mathrm{p}$.

Tese (Doutorado) - Escola de Enfermagem da Universidade de São Paulo.

Orientadora: Prof ${ }^{a}$. Dr ${ }^{a}$. Ana Maria Kazue Miyadahira.

Co-orientadora: Prof ${ }^{a} \mathrm{Dr}^{a}$. Cilene Aparecida Costardi Ide.

1. Educação em enfermagem 2. Educação baseada em competências

3. Competência profissional 4. Prática profissional 5. Construtivismo (educação) I. Título. 
Confia no Senhor de todo o teu coração e não te estribes no teu próprio entendimento. Reconhece-o em todos os teus caminhos, e ele endireitará as tuas veredas.

Provérbios 3.5-6 


\section{DEDICATÓRIA}

Dedico este trabalho a você CILENE:

Por estar presente na construção do "corpo e alma" desse estudo; por ser competente e ter tido a paciência, respeitando o meu tempo necessário para eu construir as minhas competências; pela oportunidade impar do convívio com uma pessoa inteligente, sensível, de relações postas no respeito pelo outro e na afetividade... pela possibilidade de criar algo com o seu total apoio.

Obrigada de Coração! 


\section{Agradecimento Especial}

Ana, agradeço por ter respeitado um desejo, que para mim fez-se importante na minha trajetória profissional.

Agradeço pois foi minha orientadora desde o mestrado, sendo o meu primeiro contato pessoal nesta Escola que tanto prezo.

Obrigada de Coração! 


\section{Agradecimentos}

Construir não é um verbo que traz uma só ação...

Construir significa ter sonhos, projetá-los perante a realidade, dar significados, re-significá-los, pensar nas metas e trabalhar muito, para desenvolvê-las, para vivê-las.

Construir significa também explicar para o filho Marco Antônio que certa vez me perguntou "mamãe por que você erra tanto e tem que corrigir, corrigir..." Explicar para o João Vitor que perguntava "mamãe você vai no São Paulo de novo"? Explicar que é um processo de construção com as suas implicações.

Nessa complexidade é que as interações humanas aconteceram e muitas vezes não puderam ser efetivadas, com a qualidade que eu desejava. Porém, foi o possível para esse tempo longo de criação.

Diante disto, eu quero carinhosamente agradecer:

- primeiramente a Deus, Senhor da minha vida, razão de tudo;

- a minha família representada pelo Marcos, Marco Antônio e João Vitor, pela expressão de amor;

- a Dona Maria, por cuidar da casa e dos meus filhos;

- a Edvane, amiga e pesquisadora da melhor qualidade;

- a Wilza minha amiga e "irmã" por sempre alimentar a esperança em $\operatorname{mim}$;

- a Silvia e Janete minhas amigas/colegas de disciplina, por toda força; 
- a Carmen, Maria Alice, Regina, Eliana, Vilanice, pelo carinho;

- aos Alunos que compuseram a população de forma pronta;

- os funcionários do Departamento de Enfermagem, em especial o Agnaldo, Fernanda, Daniela, Rosa, Denise e Dona Maria pela colaboração, atenção e carinho;

- a Meire por realizar as correções nas referências bibliográficas;

- a CAPES pelo apoio financeiro;

- a UNESP, instituição que trabalho onde também tenho espaço para criar;

- enfim... todos que interagiram comigo nessa trajetória, que em outra etapa espero poder dar seqüência para eu continuar a Aprender, Aprender a conviver, Aprender a ser... 


\section{RESUMO}

Dell'Acqua MCQ. A construção da competência clínica: da concepção dos planejamentos de ensino às representações da aprendizagem entre graduando de Enfermagem. [tese]. São Paulo (SP): Escola de Enfermagem da USP; 2004.

Pensar a formação de enfermeiros pressupõe articular essa questão às expressões de referenciais teóricos, na perspectiva de uma vertente pedagógica que passe pelo construtivismo e por competências. Assim, os objetivos foram: caracterizar, numa visão longitudinal, a proposição competências assistenciais na graduação; identificar o potencial de competência clínica de graduandos de Enfermagem; analisar representações discentes relativas à aprendizagem das experiências clínicas e propor referenciais para a construção da competência clínica no âmbito da Graduação em Enfermagem. O estudo foi de natureza qualitativa; os sujeitos foram alunos do último semestre da graduação, num total de 29 participantes; foi realizada análise documental dos planos de ensino das disciplinas assistenciais da graduação e utilizou-se também a Técnica do Incidente Crítico (TIC) como estratégia metodológica apta a identificar experiências significantes para a aprendizagem clínica. A instituição de ensino e os sujeitos aceitaram participar do estudo, conforme as recomendações ético-legais. Os dados evidenciaram uma organização curricular centrada em disciplinas, com modalidades organizativas que partem do genérico para o específico, mantendo lógicas internas aparentemente refratárias à organizações somativas. Uma direção da aprendizagem voltada à execução metódica de práticas em evolução, escolhidas pelos docentes, estimulando a inserção discente em programações pré-estabelecidas e reiterativas. A ligação das atividades de ensino à vida real se faz por meio de práticas em campo que respondem timidamente à problematização da realidade. As intervenções parecem ser privilegiadas segundo uma ordem externa, às vezes distante da realidade dos alunos. Emergem também, sinalizações de uma aprendizagem com vínculos pouco substantivos entre os conhecimentos prévios e a potencialização do julgamento crítico e do raciocínio clínico. Como proposição, o estudo trouxe reconsiderações para o processo ensino-aprendizagem e a influência da concepção construtivista na proposição das competências clínicas.

Palavras-chave: Educação em enfermagem, Educação baseada em competências, Competências profissionais, Prática profissional, Construtivismo. 


\begin{abstract}
Dell'Acqua MCQ. The building of clinical competence: from teaching planning apprehension to learning expression among Nursing graduate students (thesis) São Paulo (SP): "Escola de Enfermagem da USP"; 2004.

Conceiving nurse graduation is an assumption to utter this question to theoretical reference expressions, in prospect of a pedagogical under discussion, which entails constructivism and competences. Therefore, the aims were: to characterize under a longitudinal view, assistance competence propositions on graduation; to identify clinical competence potential of Nursing graduate students; to analyze student body representations related to learning of clinical experiences and suggest information to construct clinical competence on Nursing Graduation field of action. The study was a qualitative one; individuals were students at the last graduation semester with a total of 29 participants; a documentary analyses was performed on teaching plans of graduation assistance subjects and Critical Incident Technique (CIT) was also used as a methodological strategy prone to identify significant experiences for clinical learning. The Institution and the individuals agreed to participate according to ethical and legal recommendations. Data has shown a subject -centered syllabus system with organized features which comes from the general to the specific, keeping apparently inflexible inner logic to adding organizations. A learning direction toward methodical performance of ongoing practices chosen by teachers, stimulating students participation in pre-established and reiterative programs. The link of learning activities to real life is done by field practices, which timidly responds to reality problems. Interventions seem to be privileged according to an external order sometimes distant from students reality. It also emerges a signaling of a learning with poor substantial bonds among previous knowledge and critical thinking potentialization and clinical reasoning. As a postulate, the study brought reconsiderations for teaching-learning process and the influence of constructivism conception on clinical competence postulating.
\end{abstract}

Key words: Nursing education, Competence-based education, Professional competence, Professional practice, Constructivism 


\section{LISTA DE QUADROS}

Quadro 1 - A disposição das disciplinas assistenciais na estrutura curricular da graduação

Quadro 2 - Componentes dos planos de ensino das disciplinas assistenciais: Introdução à Enfermagem, Fundamentos de Enfermagem e Enfermagem Médico-Cirúrgica

Quadro 3 - Componentes dos planos de ensino das disciplinas assistenciais: Enfermagem em Centro Cirúrgico, Enfermagem em Doenças Transmissíveis

Quadro 4 - Componentes dos planos de ensino das disciplinas assistenciais: Enfermagem Pediátrica, Enfermagem Ginecológica, Obstétrica e Neonatal

Quadro 5 - Componentes dos planos de ensino das disciplinas assistenciais: Enfermagem Psiquiátrica, Enfermagem Preventiva e Comunitária

Quadro 6 - Caracterização do perfil e trajetória escolar pregressa

Quadro 7 - Caracterização do desenvolvimento discente complementar a graduação

Quadro 8- A construção processual da competência clínica segundo representações discentes

Quadro 9 - A construção processual da competência clínica segundo representações discentes

Quadro 10 - Caracterização dos incidentes críticos segundo a natureza dos eventos

Quadro 11 - Justificativas para a identificação do incidente crítico

Quadro 12 - Justificativas para a identificação do incidente crítico 


\section{LISTA DE ESQUEMAS}

Esquema 1- Caracterização discente considerando hábitos de vida

Esquema 2- Representações identitárias do ser discente

Esquema 3- Caracterização dos projetos profissionais dos graduandos.

Esquema 4- Componentes do conceito "Competência Clínica" elaborados pelos discentes 


\section{SUMÁRIO}

\section{RESUMO}

\section{ABSCTRACT}

\section{LISTA DE QUADROS}

\section{LISTA DE ESQUEMAS}

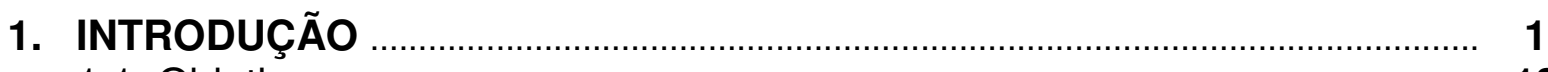

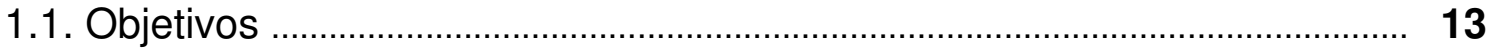

2. TRAJETÓRIA TEÓRICO-METODOLÓGICA ……...................................... 15

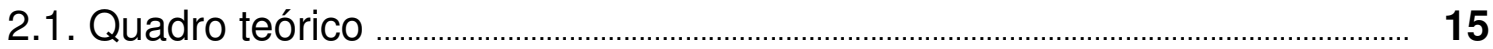

2.1.1. Os princípios construtivistas .................................................................. 15

2.1.2. Os pressupostos que norteiam a construção das competências $\mathbf{3 1}$

2.2. Abordagem metodológica ............................................................................ 37

2.3. Local do estudo ..................................................................................................... 43

2.4. Sujeitos da pesquisa ........................................................................................................ 47

2.5. Aspectos éticos ……........................................................................................................ 47

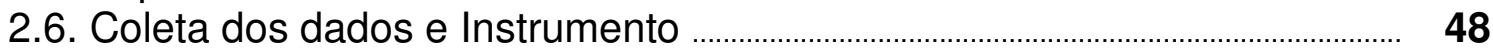

2.7. Análise dos dados ................................................................................. 49

3. APRESENTAÇÃO DOS RESULTADOS E ANÁLISE DOS DADOS ................. 52

3.1. As intenções educativas e o ensino de competências clínicas: o planejamento disciplinar em destaque ................................................................... 52

3.2. Representação da aprendizagem entre graduandos ........................................ 69

3.2.1. Caracterização do grupo discente ....................................................... 72

3.2.2. Conceitos de competência sob o prisma discente .............................. 98

3.2.3. Representações da aprendizagem das competências clínicas .... 103

3.2.4. Representações discentes relacionadas à expressão da competência clínica na prática ............................................................................ 116

3.3. Incidente crítico como estratégia de análise da aprendizagem clínica ....... 120

3.3.1. A natureza das experiências .................................................................... 121

3.3.2. As reações ao incidente crítico …………………………............................... 137

4. CONSIDERAÇÕES FINAIS ................................................................................... 149

4.1. Contribuição para uma reconsideração do processo de ensino-aprendizagem

4.2. A influência da concepção construtivista na constituição das competências clínicas

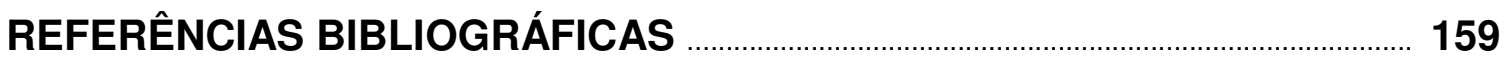

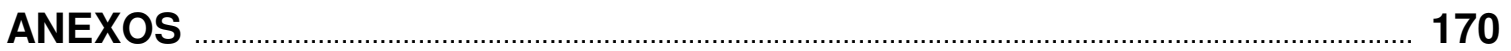


INTRODUÇÃO E OBJETIVOS 


\section{INTRODUÇÃO}

Considerando a complexidade em que os processos de formação profissional ocorrem, o investimento desta pesquisa é buscar compreender quais perspectivas educativas vêm permeando a construção de competências clínicas na Enfermagem. Tendo como referência um contexto específico de graduação, esse questionamento destaca a confluência das interações entre os processos de formulação e de experimentação, enquanto expressões de um projeto de capacitação para a realização das infinitas potencialidades da prática assistencial.

Esse processo de desenvolvimento de competências clínicas encontra-se situado em contexto cultural e socialmente regulados, entrelaçando o mundo do trabalho e da formação, delineando possibilidades de interação entre objetivos, valores, concepções e ações prevalentes em ambos; cabendo identificar expressões dessa confluência enquanto elementos norteadores de dinâmicas de formação.

No âmbito do trabalho, Machado(1) referindo Reich caracteriza os trabalhadores atuais como pertencentes a duas classes, que não são mutuamente exclusivas:

- "Os seguidores de rotinas, que realizam um trabalho repetitivo, quase sempre um trabalho em migalhas, com poucas possibilidades de criação;

- Os analistas simbólicos, que conseguem uma visão global do que produzem, da concepção à produção, seja de bens ou de serviços, mantendo vivas as possibilidades de criação; 
- Essas classes - rotineiros e analistas - não são mutuamente exclusivas; em todas as atividades existem rotinas necessárias e nem tudo é criação. Porém, a preservação do espaço aberto para a criação é condição de possibilidade de uma vida significativa...(1)

Tendo por base esse referencial é possível considerar que o processo de trabalho em saúde caracteriza-se, ao mesmo tempo pela complexidade, heterogeneidade e a fragmentação. A complexidade é decorrente da diversidade das profissões, dos profissionais, dos usuários, das tecnologias utilizadas, das relações sociais e interpessoais, das formas de organização do trabalho. A heterogeneidade retrata-se pela diversidade de muitos processos de trabalho que coexistem nas instituições de saúde e que têm, muitas vezes, uma organização própria e funcional sem se articular de forma adequada com os demais processos de trabalho. A fragmentação encerra várias dimensões, tais como a fragmentação conceitual, ou seja, a separação entre o pensar e o fazer; a fragmentação técnica, caracterizada pela presença cada vez maior de profissionais especializados e a fragmentação social, que estabelece relações rígidas de hierarquia e subordinação, configurando a divisão social do trabalho no interior e entre as diversas categorias profissionais $^{(2)}$.

Essa divisão do trabalho configura-se enquanto elemento e produto da forma gerencial taylorista/fordista, caracterizada por postos de trabalho separados, mas encadeados, tarefas simples e rotineiras, prescritas, intensa divisão técnica do trabalho com a separação entre concepção e execução e grande contingente de trabalhadores semi-qualificados com um mínimo de possibilidade de intervenção autônoma no processo de trabalho ${ }^{(3)}$. 
Também na Enfermagem é possível identificar espaços e expressões das duas tendências. Por um lado, há uma prática reiterativa, fragmentada, às vezes, pouco sustentada cientificamente, compatível, portanto; com expressões profissionais rotineiras. Cabe considerar, inclusive, que é na Enfermagem que o modelo taylorista encontra sustentação, na medida em que profissionais e doentes seriam versões parciais de um todo pouco constituído. Assim evidencia-se:

"a força do modelo funcionalista dificultando produções de sentido que invistam na construção de projetos de ação mais integrais, impregnados de noções que reconheçam a complexidade da natureza humana... Modelo cuja vigência redutora dificulta a validação de atos mais sensíveis a essa expressão do humano que, uma vez implementados, colidem com as defesas e acabam sendo reduzidos à rotinas... Modelo cuja expressão operacional expulsa de forma direta ou indireta, os profissionais capazes de perceber e de reagir ao seu princípio desintegrador e desagregador,4)

Porém, a expectativa e o espaço para iniciativas inovadoras, criativas também já se faz presente nesse contexto de prática. Gradativamente, o mercado em saúde se abre para os analistas simbólicos, aqueles que irão por desafio propor novas bases para práticas assistenciais em transformação e em expansão.

Já é perceptível a tendência de substituir o trabalho não-qualificado, fragmentado, repetitivo, rotineiro e prescritivo, que foi característico do modelo taylorista/fordista; por um trabalho polivalente, integrado, em equipe, com mais flexibilidade e autonomia. Faz-se necessário ter condições para diagnosticar, prevenir, antecipar, decidir e interferir, isto em situação concreta de trabalho. Existe a natureza de imprevisibilidade das situações, tendo que fazer escolhas e optar o tempo todo, ampliando-se as operações mentais e cognitivas. Portanto, é preciso ter 
a capacidade de realizar diagnósticos e de solucionar problemas, bem como aptidão por tomar decisão ${ }^{(3)}$.

O contexto atual é de mercado de trabalho instável e flexível, com exigências crescentes de produtividade e de qualidade, e isto, amplia os requisitos de qualificação dos trabalhadores e tornam cada vez mais generalizada a implantação de modelos de formação e de gestão da força de trabalho baseados em competências profissionais. As novas exigências do trabalho requerem, além da flexibilidade técnico-instrumental, a flexibilidade intelectual, tendo em vista as necessidades de melhoria contínua dos processos de produção de bens e serviços $^{(3)}$.

Entretanto, essa competência pretendida também não é inócua, podendo gerar crescimento circunscrito, tornando o profissional "refém do trabalho na luta pela garantia da sobrevivência, envolvendo-se cada vez mais com uma tarefa e com um grupo, sofrendo uma crescente imposição do espaço do trabalho no seu espaço de vida"(5).

Nesse sentido, a competência seria um requisito privilegiado para a empregabilidade, porém seu exercício pressupõe. ${ }^{(6)}$

- "A necessidade de ser eternamente competente ou desempregado;

- A necessidade de ser competente e, ao mesmo tempo, ser pertinente à estrutura e à cultura de trabalho ainda contaminada pela burocracia e hierarquia $^{(, 6)}$.

Pode-se considerar que além dessas duas necessidades uma terceira iniciativa passa a ser relevante na consolidação da expressão profissional do enfermeiro, ou seja, a constituição da competência clínica enquanto uma das balizas identitárias da sua exigência no âmbito dos profissionais de nível superior em saúde. 
Na questão clínica, "a mobilização pode estar pautada no resgate de um poder que, tendo o paciente não mais como objeto também de controle e subordinação, mas como um indicador da qualidade de trabalho da Enfermagem, necessita atendê-lo além do papel de vigilante das ações dos auxiliares encarregados do atendimento das necessidades fisiológicas básicas e do cumprimento da prescrição médica". ${ }^{(6)}$

Construir, portanto, novos referenciais para uma ação competente na perspectiva clínica passa a ser, agora, um desafio significante para a graduação em Enfermagem, cabendo questionar:

- Quais concepções de competência norteiam os planejamentos de ensino no âmbito assistencial?

- Como se dá o encadeamento e a continuidade das unidades de formação especialmente a partir da perspectiva clínica?

- Que aproximações existem entre tais formulações e os referenciais teóricos preconizados no estudo?

- Que representações dessa aprendizagem impregnam as perspectivas discentes?

Diferentes pesquisadores já vêm desenvolvendo estudos voltados à compreensão dos fenômenos inerentes à experiência do ensinar e do aprender a cuidar. $^{(7,8,9,10,11)}$ Apesar da diversidade dos cenários, dos sujeitos e das abordagens teórico-metodológicas, os resultados dessas pesquisas, segundo lde e De Domenico $^{(12)}$ apontam para:

- "A percepção de uma experiência de profissionalização que, apesar de inscrita numa ordem essencial de aprender a cuidar do ser humano, 
ainda convive com esquemas de pensamento frágeis em suas premissas e com projetos de ação impotentes frente a uma realidade de prática representada pelos participantes como imutável e absoluta;

- O reconhecimento de uma cisão entre as produções de sentidos e a realidade da prática, configurando uma dissociação entre os projetos de atuação veiculados pela graduação e o cotidiano institucional balizado pelo taylorismo;

- A consciência do padrão de eficiência pertinente, limitando o espaço de criação e de autonomia profissional;

- A expressão de uma noção de contradição entre o que é possível desejar e pensar a respeito do cuidar e uma representação da realidade que imobiliza projetos, promovendo uma percepção de descompasso e uma sensação de despreparo e de impotência para a superação do interdito (real ou imaginário), projetado numa instituição apresentada como estruturante e estruturada;

- Tendo esses dados a reiteração da existência de uma "célula germinativa" comum ao sistema de graduação, quase impermeável às diferentes mobilizações promovendo uma inserção de sujeitos no ser conjunto fragilizados pelo distanciamento entre os mundos da formação e do trabalho. Reconhecer esse distanciamento e apostar em novas condutas pedagógicas que reflitam novos comportamentos profissionais são fundamentais para que avancemos para além das rotinas e da conformação".(12) 
Outra pesquisa relevante nesse âmbito de investigação foi desenvolvida por Matheus ${ }^{(8)}$, tendo por objetivo a compreensão das interações entre os elementos significativos do cuidado apreendido na graduação e o experimentado na prática, cabendo destacar que:

- "Convivendo com dilemas relativos à continuidade, a recém-formada projeta formas de sobrevivência, de superação, tendo no cuidar uma referência e uma ponte para firmar sua própria existência. O sentido de ser e de cuidar foram redimensionados para abrigar novos perfis, mantendo a força da demanda interna por cuidar".(8)

É possível identificar, portanto, na prática assistencial a ser resignificada em desafio significante para os enfermeiros na medida em que:

"Desvendando a automação, potencializando a coragem de ousar no reencontro do ritmo de origem, reconstruindo o seu espaço no seio da criação destacada da instituição, transformado em expressão de autonomia, de responsabilidade, de decisão, enfim, de competência, configura-se um gesto profissional compatível com os desafios de uma nova prática".(13)

Evidencia-se, assim, espaço para novos investimentos em formação, no sentido de adequá-lo à concepções pedagógicas que incluam o referencial de competência possibilitando, inclusive, reconsiderar os dispositivos legais que norteiam a formação superior em Enfermagem. Nessa perspectiva este estudo privilegia uma concepção construtivista.

Competência para Perrenoud(14), é apresentada como sendo "uma capacidade de agir eficazmente em um determinado tipo de situação, apoiada em conhecimentos, mas sem limitar-se a eles. O conhecimento faz parte de vários recursos cognitivos complementares, isto proporcionará enfrentar uma situação da 
melhor maneira possível. O conhecimento é uma ferramenta importante da competência, porém apenas detê-lo não assegura uma ação competente, fazem parte também a capacidade (e a coragem) para inovar associada a outras habilidades cognitivas e comportamentais e isto, configura o perfil do indivíduo competente. As competências manifestadas em diferentes ações, como: construir uma hipótese e verificá-la, argumentar sobre um texto lido, resolver um problema clínico, não são, em si, conhecimentos; elas "utilizam, integram ou mobilizam tais conhecimentos".

A construção de competências está atrelada a formação de esquema de mobilização dos conhecimentos com discernimento em prol de uma ação eficaz. Os esquemas de mobilização de diversos recursos cognitivos em uma situação de ação complexa desenvolvem-se e estabilizam-se na prática. No ser humano não se aplica a programação de esquemas por uma intervenção externa. O sujeito também não pode construí-los por simples interiorização de um conhecimento procedimental. A construção dos esquemas ocorrem por treinamento de experiências renovadas, ao mesmo tempo redundantes e estruturantes, e isto torna-se mais eficaz quando associado a uma postura reflexiva. O tempo para viver as experiências e a possibilidade de analisá-la é que vai proporcionar este treinamento ${ }^{(14)}$.

A abordagem pelas competências tem-se desenvolvido nos países anglosaxões e está ganhando força no mundo francófono. Na Bélgica, no Canadá e particularmente na França esta abordagem é muito utilizada. $O$ que justificaria a ascensão da abordagem por competência, passaria pela noção de que como o mundo do trabalho apropriou-se da noção de competência, a escola, sob pretexto de modernizar-se está seguindo seus passos, inserindo-se nos valores do mercado de trabalho, como gestão de recursos humanos, busca da qualidade total, valorização 
da excelência, exigência de uma maior mobilidade dos trabalhadores e da organização do trabalho. As universidades desde a formação do ensino médio e profissionalizante, não tem destinado tanto prestígio a esta abordagem, preferindo enfatizar o saber erudito, teórico e metodológico ${ }^{(14)}$.

Para responder à necessidade de mudança o sistema formador em saúde tem como desafio maior investir na inserção desse referencial da constituição de balizas para o desenvolvimento da competência clínica, considerada ao mesmo tempo:

- "Como um trabalho de construção de conceitos e de novos saberes teóricos (ao menos para o estudante) a partir de situações singulares;

- Um trabalho de integração e de mobilização de recursos adquiridos, criador de competências".(15)

Assim, o exercício da competência clínica está muito distante de ser um simples exercício de reconhecimento de casos escolares e de aplicação da resposta ortodoxa. "É preciso construir tanto o problema como sua solução, refletir, observar os dados em todos os sentidos, dar-Ihes consistência, esboçar hipóteses e analisálas detalhadamente por meio do pensamento, em um "mundo virtual" onde tudo continua sendo reversível".(15)

A clínica também é um espaço fundamental para colocar em prática "as aquisições teóricas e metodológicas. Passa-se a trabalhar a mobilização, a orquestração, a sinergia e a contextualização de saberes já construídos, mas que o estudante ainda não pôde utilizar diante de situações complexas".(15)

Nesse contexto, ela exerce uma dupla função... "formação teórica a partir do singular e o treinamento contextualizado das ações terapêuticas. A segunda função obriga os estudantes a agirem como profissionais, apesar dos prós e contras, 
a elaborar ou adiar um diagnóstico, a propor outros exames ou uma primeira ação terapêutica. Portanto, para o interno, é o momento de refletir na situação e na ação, da forma mais rápida e melhor possível, ao alcance do olhar do paciente, dos colegas e do diretor da clínica”.(15)

No que diz respeito a formação profissional, "o procedimento clínico representa uma grande mudança com relação ao modelo clássico, o qual estabelece que a teoria precede a ação que supostamente a aplicará mediante um pouco de intuição, de Know How e de imaginação. No procedimento clínico, a teoria é desenvolvida a partir da ação em função de uma espiral: uma primeira construção conceitual fornece uma grade de leitura do que ocorre ou ocorreu, ao mesmo tempo em que a realidade enriquece e diferencia o modelo. Um procedimento clínico não substitui saberes eruditos por intuições inconsistentes e não dispensa a pesquisa fundamental e aplicada. Trata-se de um procedimento de formação, de apropriação ativa dos saberes confrontados com a realidade. Esse procedimento também permite articular saberes acadêmicos, oriundos de uma metodologia rigorosa, mas que não abarcam toda a realidade, e saberes profissionais, que "funcionam", muitas vezes, sem se saber por quê. O estudante descobre, com bastante eficiência, que não há situações complexas sem pistas de inteligibilidade e que nenhuma teoria erudita permite enfrentar, de forma infalível, uma situação complexa”.(15)

No ensino clínico, "a passagem é uma reflexão distanciada, longe do calor da ação, não é produto do acaso. O papel dos formadores também é estimular a reflexão dos alunos antes e depois de situações semelhantes. Na medida em que a observação evidencia bases teóricas ou metodológicas frágeis, ou gestos pouco controlados, faz com que se passe a uma reflexão sobre o sistema de ação tanto em seu componente consciente e racional (saberes declarativos e procedimentais, 
raciocínios explícitos) como em suas dimensões menos reflexivas, provenientes do habitus e do inconsciente prático".(15)

Esses pressupostos em alguma medida podem ter nutrido a proposição das Diretrizes Curriculares Nacionais do Curso de Graduação em Enfermagem ${ }^{(16)}$, ao evocar as seguintes competências e habilidades gerais e específicas.

“I - Atenção à saúde;

II - Tomada de decisões;

III - Comunicação;

IV - Liderança;

V - Administração e gerenciamento;

VI - Educação permanente; e no artigo $5^{\circ}$ a formação do enfermeiro tem por objetivo dotar o profissional dos conhecimentos requeridos para 0 exercício das seguintes competências e habilidades específicas: citadas de I a XXXIII". ${ }^{(16)}$

Entretanto sua formulação denota uma apropriação questionável do conceito "competência" na medida em que:

- Agrega uma multiplicidade de expressões performáticas, nem todas constitutivas de competências. Enfatizam ao mesmo tempo áreas e âmbitos de atuação, recursos a serem mobilizados, habilidades, diferentes tipologias de conteúdos como expressões de competência, incorrendo numa distorção conceitual;

- Possui uma configuração que aparentemente não reconhece expressões de realidade, atribuindo-se capacidades que transcenderiam uma atuação profissional ainda que competente. Nesse sentido, cabe reiterar que "a referência à idéia de competência 
nunca pode prescindir da consideração do âmbito, do contexto no qual ela se realizará”.(1)

- Contraditoriamente a essa expressão, a noção de pessoalidade enquanto característica absolutamente fundamental da idéia de competência não se apresenta com clareza. Ao limitar a formação à uma única saída (generalista) aparentemente interdita percursos de formação alternativos, considerando necessidades, expectativas e possibilidades peculiares; $;^{(1)}$

- Parece não considerar a mobilização como elemento fundamental na composição da idéia de competência, superando a noção de conhecimento acumulado para indicar a "capacidade de recorrer ao que se sabe,(1);

- Não incorporar indicativos de resolutividade às ações propostas, aparentemente desconsiderando a "capacidade de agir eficazmente em um determinado tipo de situação apoiada em conhecimentos, mas sem limitar-se a eles"(14), como uma expressão de competência;

- Seleciona e nesse sentido, determina, conteúdos de formação, não indicando possibilidades alternativas, operacionais ou complementares à essa constituição, promovendo limitações a reformulações que considerem novas demandas de formação e de aluno em Enfermagem.

Frente a essas reflexões é possível considerar hipoteticamente, que as balizas para a formação do enfermeiro incluindo o desenvolvimento da competência clínica, ainda encontram-se pouco consolidados na cultura de formação superior em Enfermagem. 
Assim sendo, na tentativa de contribuir para o aprimoramento do processo de formação em Enfermagem, buscando apreender o sentido e a consistência das concepções e experiências de ensino/aprendizagem inerentes à graduação, considerando os referenciais preconizados, desenvolveu-se esta pesquisa, cujos objetivos encontram-se expressos a seguir.

\subsection{Objetivos}

- Caracterizar numa visão longitudinal a proposição competências assistenciais na graduação.

- Identificar o potencial de competência clínica de graduandos de Enfermagem.

- Analisar representações discentes relativas à aprendizagem das experiências clínicas.

- Propor referenciais para a construção da competência clínica em Enfermagem. 


\section{TRAJETÓRIA TEÓRICO-METODOLÓGICA}




\section{TRAJETÓRIA TEÓRICO-METODOLÓGICA}

Tendo por base a realidade de uma prática de formação em Enfermagem, buscou-se identificar expressões de competência por ela mobilizadas, numa dupla perspectiva, incluindo apreciações docentes e representações discentes relativas ao ensino/aprendizagem das experiências clínicas vividas nas diferentes disciplinas assistenciais, visando potencializar decisões relativas ao aprimorando da graduação.

\subsection{Quadro teórico}

Mobilizar a graduação para além da sua conformação atual, organizando situações de aprendizagem pautada numa abordagem construtivista e em referenciais de competência profissional, requer as bases analíticas que serão constituídas considerando:

- Os princípios construtivistas

- Os pressupostos que norteiam a construção das competências

\subsubsection{Os Princípios Construtivistas}

O construtivismo é um movimento que tem suas bases na filosofia, sendo que, suas vertentes solidificaram-se no começo do século XX. Encontram-se entre os construtivistas Jean Piaget, epistemólogo suíço, o psicólogo e médico francês Henry Wallon e o psicólogo russo Lev S. Vygotsky. Há porém, diferentes visões de mundo e posições teóricas, embora utilizem paradigmas diferenciados, esses 
construtivistas defendem o papel social na construção do processo do conhecimento. $^{(17)}$

O construtivismo é sustentado pela idéia que o indivíduo, "tanto nos aspectos cognitivos e sociais do comportamento como nos afetivos, não é um mero produto do ambiente nem um simples resultado de suas disposições internas, mas, sim, uma construção própria que vai se produzindo, dia a dia, como resultado da interação entre esses dois fatores". ${ }^{(18)}$ Os instrumentos de construção que a pessoa utiliza, fundamentalmente são os esquemas que já possui, com o que já construiu em relação com o meio que a rodeia. ${ }^{(18)}$

Nessa perspectiva, "o ser humano não nasce com os conhecimentos, mas que estes são construídos por internalização e reconstrução através da ação, isto é pela interação do indivíduo com o meio físico e social, constituindo uma verdadeira teia de relações sociais".(17)

No construtivismo a aprendizagem passa pela concepção de uma construção pessoal que cada aluno realiza utilizando-se da ajuda que recebe de outras pessoas. Nesta construção pode-se atribuir significado a um determinado objeto de ensino, implica no envolvimento por parte da pessoa que aprende, do seu interesse e disponibilidade, bem como, de seus conhecimentos prévios e de sua experiência. $^{(19)}$

Então sobre o ensino, a concepção construtivista é um conjunto articulado de princípios que propiciam diagnosticar, julgar e tomar decisões fundamentais ${ }^{(20)}$. Constitui portanto, um instrumento importante para a tomada de decisão sobre o planejamento, para a análise das situações educativas e, ao mesmo tempo aplicação e avaliação do ensino. 
De acordo com os pressupostos construtivistas a aprendizagem, está intimamente entrelaçada com o desenvolvimento humano uma vez que o aprender depende da capacidade de elaborar uma representação pessoal sobre um objeto da realidade ou de um conteúdo ${ }^{(20)}$.

Ainda nessa perspectiva "a aprendizagem é a progressiva mudança de comportamento que está ligada, de um lado, a sucessivas apresentações de uma situação e, de outro, a repetidos esforços dos indivíduos para enfrentá-la de uma maneira eficiente"(21);

Nesse processo, a iniciativa para o aprendizado advém de experiências, interesses e conhecimentos prévios que aproximam o indivíduo do "algo" a ser aprendido. Na etapa posterior, os significados a serem atribuídos a esse "algo" são constituídos “...na integração, modificação, estabelecimento de relações e coordenação entre esquemas de conhecimento que já possuímos, dotados de uma certa estrutura e organização que varia, em vínculos e relações, a cada aprendizagem que realizamos,(20).

Então, cada novo aprendizado ocorre no estabelecimento de interações com os conhecimentos integrados anteriormente nos esquemas de conhecimento e conceitos já constituídos pelo indivíduo. Os esquemas de conhecimento são compostos por uma variedade de tipos de conhecimento sobre a realidade, incluindo informações sobre fatos, acontecimentos, experiências, atitudes, normas, valores, conceitos, explicações, teorias e procedimentos relacionados a essa realidade ${ }^{(22)}$.

Conforme refere Coll (23) "(...) o desenvolvimento dos seres humanos não ocorre nunca no vazio, mas sim que tem lugar sempre e necessariamente dentro de um contexto social e cultural determinado. As pessoas se constituem como tais, graças à interação que mantém desde o momento do nascimento - e talvez mesmo 
antes - com um meio ambiente culturalmente organizado. O crescimento pessoal deve ser entendido como o processo através do qual os seres humanos tornam seus os conhecimentos e formas culturais do grupo social ao qual pertencem".

No processo de assimilação há uma reconstrução ou reelaboração do conhecimento pelo próprio indivíduo, tornado-o único, ainda que considere como parte de um grupo socialmente constituído. Com isto, os indivíduos podem viver as experiências e significá-las de forma peculiar, situações estas mediadas pela qualidade, diferenciação e coordenação dos esquemas de conhecimento já incorporados e por sua relevância e pertinência para estabelecer vínculos com uma nova informação ${ }^{(24)}$.

Portanto, quando se aborda a concepção do processo educativo, cabe salientar que:

- Um dos objetivos fundamentais da educação é a modificação dos esquemas de conhecimentos dos alunos; ${ }^{(19)}$

- A concepção construtivista pressupõe que nossa estrutura cognitiva está configurada por uma rede de esquemas de conhecimentos; ${ }^{(19)}$

- Que "os esquemas se definem como as representações que uma pessoa possui, num momento dado de sua existência, sobre algum objeto de conhecimento. Ao longo da vida, estes esquemas são revisados, modificados, tornam-se mais complexos e adaptados à realidade, mais ricos em relações". ${ }^{(19)}$

- Quanto "a natureza dos esquemas de conhecimento de um aluno depende de seu nível de desenvolvimento e dos conhecimentos prévios que pôde construir";,(19) 
- E “...podemos dizer que está se produzindo uma aprendizagem significativa quando "os alunos diante destes conteúdos passam a atualizar seus esquemas de conhecimentos, compará-los com o que é novo, identificar semelhanças e diferenças e integrá-las em seus esquemas, comprovar que o resultado tem certa coerência. ${ }^{\text {,(19) }}$

- A intervenção pedagógica é concebida “...como uma ajuda adaptada ao processo de construção do aluno; uma intervenção que vai criando Zonas de Desenvolvimento Proximal e que ajuda os alunos a percorrelas"(19);

- A Zona de Desenvolvimento Proximal (ZDP) descrita por Vygotsky ${ }^{(76)}$, pode ser definida como o espaço no qual, com a interação e ajuda de outros, uma pessoa pode resolver um problema ou realizar uma tarefa, porém de uma maneira ainda não completamente independente ${ }^{(19)}$;

- Essa ajuda deve conjugar duas grandes características: "a) tomar como ponto de partida os esquemas de conhecimentos já constituídos pelos alunos; b) provocar desafios que os levem a questionar esses significados e sentidos, direcionando a mudança para o sentido desejado,(19);

- Os conhecimentos prévios trazidos pelos alunos têm por características: "a) a construção pessoal; b) procurar a utilidade mais do que a "verdade"; c) serem compartilhados por outras pessoas, com a possibilidade de agrupá-los em tipologias; d) possuir um caráter implícito (descobertos em atividades, ações); e) serem estáveis e resistentes à mudança; f) possuir coerência do ponto de vista do aluno, não do ponto de vista científico ${ }^{(23)}$; 
- Favorecer a criação da ZDP significa proporcionar ao aluno a possibilidade de construir, modificar, enriquecer e diversificar esquemas de conhecimento, ou seja, proporcionar-lhe o domínio da ação futura, autônoma ${ }^{(23)}$;

- Os espaços da ZDP são dinâmicos, devem estar em constante processo de mudança, surgindo mediante as interações entre professor-aluno e alunos-alunos ${ }^{(23)}$;

- A exigência do professor deve ser acompanhada de apoios e suportes de todo tipo, "dos instrumentos tanto intelectuais como emocionais que possibilitem que os alunos superem essas exigências e desafios", tornando-os desafios abordáveis ${ }^{(24)}$;

Agregando ao referencial dos princípios educativos à dimensão do processo de ensino pode se considerar que seu direcionamento depende do trabalho sistematizado do professor, posto também no planejamento que conjuga: objetivos, conteúdos, métodos e formas avaliativas e organizativas do ensino, numa relação de mútua interdependência. ${ }^{(25)}$

Na prática educacional a intervenção pedagógica "tem um antes e um depois" que constituem em peças substanciais e são o planejamento e a avaliação desses processos educacionais. ${ }^{(19)}$

Para Zabala ${ }^{(19)}$ a concepção sobre os processos de aprendizagem agrega conceitos, valores e práticas dentre as quais selecionou-se pressupostos referidos a seguir:

- Para a educação, "um modo de determinar os objetivos ou finalidades consiste em fazê-lo em relação às capacidades que se pretende desenvolver nos alunos"(19); 
- A determinação das "finalidades ou objetivos da educação, sejam explícitos ou não, é o ponto de partida de qualquer análise da prática”.(19)

- Das diferentes formas de classificar as capacidades do ser humano, destaca-se a proposta de Coll(1986) "que estabelece um agrupamento em capacidades cognitivas ou intelectuais, motoras, de equilíbrio e autonomia pessoal (afetivas) de relação interpessoal e de inserção e

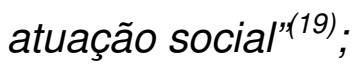

- Quanto ao termo conteúdo aludido estritamente ao caráter cognitivo deve ser revisto, "devemos nos desprender desta leitura restrita do termo "conteúdo" e entendê-lo como tudo quanto se tem que aprender para alcançar determinados objetivos que não apenas abrangem as capacidades cognitivas, como também incluem as demais capacidades;; (19)

- Quando se propõe conteúdos uma questão poderá ser feita: “...responder à pergunta o que deve se aprender?” deveremos falar, então, de conteúdos de natureza muito variada: dados, habilidades, técnicas, atitudes, conceitos, etc. ${ }^{\text {(19) }}$

- Das diferentes formas de classificar esta diversidade de conteúdos, Coll(1986) propõe uma que, como veremos, tem uma grande potencialidade explicativa dos fenômenos educativos. São os conteúdos conceituais, procedimentais ou atitudinais. Correspondendo as perguntas "o que se deve saber?", "o que se deve saber fazer"? e "como se deve ser"?, com o fim de alcançar as capacidades mencionadas. ${ }^{(19)}$ 
- Pensar em objetivos, conteúdos, aprendizagem, remete-nos a questão da avaliação, e trata-se de uma forma de intervenção extremamente complexa, com uma autêntica atenção à diversidade, que implicou estabelecer níveis, desafios, ajudas e avaliações apropriados às características pessoais; ; $^{(19)}$

- Quanto ao processo de aprendizagem considera-se que: "a aprendizagem dos conteúdos segundo sua tipologia, antes de fazê-la é necessário efetuar uma análise diferenciada dos conteúdos, e também é conveniente pensar no perigo de compartimentar o que nunca se encontra de modo separado nas estruturas de conhecimento. ${ }^{*(19)}$

- É necessário compreender que "a diferença dos elementos que os integram e, inclusive, a tipificação da característica destes elementos, que denominamos conteúdos, é uma construção intelectual para compreender o pensamento e o comportamento das pessoas".(19)

- É referido também que "em sentido estrito, os fatos, conceitos, técnicas, valores, etc., não existem. Estes termos foram criados para ajudar a compreender os processos cognitivos e condutuais"...(19)

- Com essas considerações entende-se por conteúdos factuais "o conhecimento de fatos, acontecimentos, situações, dados e fenômenos concretos e singulares: a idade, os códigos, um fato determinado num determinado momento, etc. Sua singularidade e seu caráter descrito e concreto, são um traço definidor".(19) 
- Aprende-se "os conteúdos factuais basicamente mediante atividades de cópia mais ou menos literais, a fim de ser integrado nas estruturas de conhecimento, na memória... de caráter reprodutivo...;(19)

- Avalia-se os conteúdos factuais propondo perguntas de modo individual, uma prova escrita simples, que proponha respostas a uma série de perguntas, ${ }^{(19)}$

- "Os conteúdos conceituais e os princípios são os termos mais abstratos. Os conceitos referem-se ao conjunto de fatos, objetos ou símbolos que têm características comuns, e os princípios se referem às mudanças que se produzem num fato, objeto ou situação em relação a outros fatos... descrevem relações de causa-efeito ou de correlação."(19)

- “A aprendizagem de conceitos e princípios... que permitem que sejam significativas. Trata-se de atividades complexas que provocam um verdadeiro processo de elaboração e construção pessoal do conceito... atividades que favoreçam a compreensão do conceito a fim de utilizálo para a interpretação ou o conhecimento de situações, ou para a construção de outras idéias.",;(19)

- “A avaliação dos conteúdos procedimentais implicam saber fazer, e o conhecimento sobre o domínio deste saber fazer só pode ser verificado em situações de aplicação destes conteúdos. Conhecer até que ponto sabem dialogar e avaliar cada aluno."(19)

- "Os conteúdos procedimentais inclui entre outras coisas as regras, as técnicas, os métodos, as destrezas ou habilidades, as estratégias, os 
procedimentos - é um conjunto de ações ordenadas e com um fim, quer dizer, dirigidas para a realização de um objetivo",(19)

- "A aprendizagem de um procedimento passa pela realização das ações; na exercitação múltipla como elemento imprescindível para o domínio competente; a reflexão sobre a própria atividade permite que se tome consciência da atuação; a aplicação em contextos diferenciados se baseia no fato de que aquilo que aprendemos será mais útil na medida em que podemos utilizá-lo em situações nem sempre previsíveis". (19)

- "A avaliação dos conteúdos procedimentais implicam saber fazer, e o conhecimento sobre o domínio deste saber fazer só pode ser verificado em situações de aplicação destes conteúdos. Conhecer até que ponto sabem dialogar e avaliar cada aluno."(19)

- "Os conteúdos atitudinais englobam uma série de conteúdos que por sua vez podemos agrupar em valores, atitudes e normas. Entendemos por valores os princípios ou as idéias éticas que permitem às pessoas emitir um juízo sobre as condutas e seu sentido. As atividades são tendências ou predisposições relativamente estáveis das pessoas para atuar de certa maneira. As normas são padrões ou regras de comportamento que devemos seguir em determinadas situações que obrigam a todos os membros de um grupo social., ${ }^{\text {,19) }}$

- O aprendizado de uma atitude se dá "quando a pessoa pensa, sente e atua de forma mais ou menos constante frente ao objeto concreto a quem dirige essa atitude".(19) 
- “A avaliação dos conteúdos atitudinais seus componentes cognitivos, condutuais e afetivos são consideravelmente complexos para determinar o grau de aprendizado de cada aluno. A fonte de informação para conhecer os avanços nas aprendizagens de conteúdos atitudinais será a observação sistemática de opiniões e das atuações nas atividades...,(19)

Dos critérios para avaliação do processo ensino/aprendizagem conforme as etapas já apresentadas, traz-se na releitura de De Domenico ${ }^{(6)}$ as considerações de Zabala ${ }^{(19)}$ que permite pensar no processo de avaliação como:

- "A Avaliação Formativa compreende a operacionalização de etapas que visam, primordialmente, a adequação das atividades desenvolvidas na prática com a construção das competências desejadas pelos alunos e professores".

- "Nesse modelo de avaliação, o objeto da avaliação deixa de se centrar exclusivamente nos resultados obtidos e se situa, prioritariamente, no processo/ensino/aprendizagem. As etapas são":

- "O primeiro passo do processo, a avaliação inicial, consiste em conhecer o que cada um dos alunos sabe, o que querem saber, quais os instrumentos que já dispõem, e quais as limitações já vivenciadas".

- "Tendo por base os objetivos e conteúdos de aprendizagem previstos, o professor deve estabelecer as atividades e tarefas. Na medida que o professor vai conhecendo a maneira como cada aluno aprende e comparando às necessidades de aprendizagem, alterações podem ser realizadas, neste momento o professor realiza uma avaliação reguladora". 
- "O termo "formativo" designa a "modificação e a melhora contínua do aluno que se avalia" uma vez que a valoração do processo de aprendizagem tanto pelo docente como pelo aluno oportuniza, ao aluno, propostas educacionais mais adequadas".

- "Na avaliação final, os resultados são apurados. Analisa-se o desempenho do aluno, se ele atingiu os resultados obtidos, ou seja, as competências adquiridas ou aperfeiçoadas em relação aos objetivos previstos e também se analisa o processo e o progresso de cada aluno".

- “Considerando a aprendizagem como um processo contínuo, professor e aluno devem discutir sobre o que foi desenvolvido e realizar previsões sobre o que é necessário continuar fazendo ou o que é necessário fazer de novo. Esta etapa, chamada avaliação integradora, é especialmente importante para que o aluno possa continuar sua formação considerando suas características específicas. "(De Domênico)(6)

Quanto aos critérios para seqüência de ensino/aprendizagem ou didáticas, considera-se as intenções educativas em que numa perspectiva de análise apresenta-se: "numa primeira unidade os conteúdos são fundamentalmente conceituais; na segunda unidade procedimentais, porém, com os conteúdos conceituais associados e os conteúdos atitudinais mais claros só aparecem na fase de diálogo entre professor e aluno; na terceira unidade que se chegue a conhecer conteúdos de caráter conceitual utilizando para a compreensão técnicas e procedimentos, diálogo e debate...; numa quarta unidade vemos que em praticamente todas as atividades formam a seqüência e aparecem conteúdos 
conceituais, procedimentais e atitudinais".(19)

anização dos conteúdos pode se estabelecer três graus de relações disciplinares: multidisciplinaridade, interdisciplinaridade e transdisciplinaridade: multidisciplinaridade é uma organização somativa, onde o conjunto de matérias ou disciplinas é posto simultaneamente, sem aparecer a relação entre elas; interdisciplinaridade é a interação entre duas ou mais disciplinas desde a simples comunicação de idéias até a integração recíproca dos conceitos fundamentais e da teoria do conhecimento, da metodologia e dos dados de pesquisa; transdisciplinaridade que é o grau máximo de relações entre as disciplinas, uma integração global dentro de um sistema totalizador. ${ }^{(19)}$

Assim sendo, agregando a esses princípios e pressupostos considera-se a definição de competência, que "consiste na capacidade de mobilizar conhecimentos e uni-los para uma ação dotada de conteúdos ético e moral, pertinentes ao sistema coletivo que possui. ${ }^{(26,27)}$

Para identificar os referenciais de competências profissionais, bem como analisar suas construções no âmbito educativo e da repercussão social tendo por base os postulados construtivistas, pressupõe considerar:(6)

- "O conhecimento é construído mediante um processo de elaboração pessoal’(28);

- "Um conceito é mais do que a soma de certas conexões associativas, é mais do que um simples hábito mental. É um ato real e complexo de pensamento que não pode ser ensinado por meio de treinamento, só podendo ser realizado quando o próprio desenvolvimento mental já tiver atingido o nível necessário, em qualquer idade,(19);

- O desenvolvimento de conceitos ou de significados, pressupõe o 
desenvolvimento de muitas funções intelectuais: atenção deliberada, memória, lógica, abstração, capacidade para comparar e diferenciar ${ }^{(19)}$;

- Um conceito submete-se à consciência e ao controle deliberado quando começa a fazer parte de um sistema ${ }^{(19)}$;

- A ausência de um sistema é a diferença psicológica principal que distingui os conceitos espontâneos dos científicos ${ }^{(19)}$;

- Ao aprender, o que muda não é apenas a quantidade de informação sobre um determinado tema, mas também a sua competência, a qualidade do conhecimento que possui e as possibilidades pessoais de continuar aprendendo ${ }^{(19)}$;

- Os conhecimentos estão organizados em esquemas de conhecimento dotados da capacidade de manter conexões entre si ${ }^{(28)}$;

- O "material" de que são feitos os esquemas de conhecimento são simbólicos: "não são uma cópia da realidade, mas uma construção na qual intervieram outras idéias que já possuímos e que estavam armazenadas em nossa mente, ${ }^{\text {(28); }}$

- Este material "não é o mero produto do ambiente nem simples resultado de suas disposições internas, mas, sim, uma construção própria que vai se produzindo, dia a dia, como resultado da interação desses dois fatores"(21);

- Essa construção interativa depende, sobretudo, de dois aspectos, a saber: "da representação inicial que tenhamos da nova informação e da atividade, externa ou interna, que desenvolvamos a respeito... e que se realize a partir dos esquemas pregressos, isto é, com o que já 
foi construído na sua relação com o meio"(29);

- Nos esquemas de conhecimento estão integrados conhecimentos do tipo declarativo (conceitual: definições de "coisas") e procedimental (referentes ao como fazer, realizar ações e seqüências de ações). Sendo que, esses tipos de esquema também integram atitudes, valores e referências a outros esquemas de conhecimento ${ }^{(28)}$;

- "Como em qualquer situação de percepção do real, a postura crítica exige referenciais de contraste, ${ }^{\text {,29); }}$

- Nessa construção dos esquemas de pensar e de agir é necessário analisar: como se reage diante de si próprio; qual a conduta em relação ao próximo e de que forma se reelabora a dimensão dos valores e do comportamento ético ${ }^{(12)}$;

- Na criação de novos espaços de vinculação, a reconstrução do substrato psíquico pode ser sustentada pelo investimento em tornar consciente a própria experiência, assumindo sua responsabilidade por $\mathrm{ela}^{(12)}$;

- A possibilidade de aprender e utilizar habilidades que, construindo ao invés de destruir, ajudem a viver melhor cada experiência vital, encontrando um sentido maior para o aprender a ser profissional. ${ }^{(12)}$

Os princípios da liberdade do ser humano, da sua pré-disponibilidade para pensar, julgar, decidir, com bases racionais, estão presentes nesses conteúdos construtivistas elencados. A racionalidade do ser humano nesse referencial pode ser compreendida como "descobrir qual é o modo mais eficaz de sobreviver, não egoisticamente, mas de sobreviver com os outros e de sobreviver no mundo. 
Sobreviver não somente com idéias, mas sobreviver com relações éticas, com relações de ligação com os outros, de investimento afetivo e emocional com os outros. Ai esta a racionalidade". (30)

sta, o papel ativo e protagonista do aluno não se contrapõe à necessidade de um papel igualmente ativo por parte do educador. A escolha de uma intervenção pedagógica que propicie o processo de construção do aluno, uma intervenção que crie, sucessivamente, zonas de desenvolvimento proximal, constitui o objeto de desejo para aqueles que se dedicam ao processo ensino-aprendizagem. 


\subsubsection{Os Pressupostos que Norteiam a Construção das Competências}

Atualmente, tem-se discutido de forma ampliada sobre a temática competência, tanto na esfera do trabalho, das pesquisas, como na prática educativa. Uma abordagem analítica demonstra a necessidade de ainda estender e aprofundar esta discussão.

Dos muitos autores, das diversas áreas que estudam as competências, destacou-se dentre eles o sociólogo suíço Philippe Perrenoud, cujos conceitos sustentaram a abordagem teórica.

Le Boterf citado por Perrenoud( ${ }^{(31)}$ escreveu "A competência não é um estado, mas um processo". "A competência não reside nos recursos (conhecimentos, capacidades...) a serem mobilizados, mas na própria mobilização desses recursos. A competência pertence à ordem do "saber mobilizar". Para haver competência, é preciso que esteja em jogo um repertório de recursos (conhecimentos, capacidades cognitivas, capacidades relacionais...). "O potencial de competência não reside em um estoque inicial de conhecimentos ou capacidades que se trata de atualizar até uma situação limite, mas de uma capacidade de inferência capaz de produzir informações novas a partir de representações existentes e em função de um contexto particular que condiciona sua possibilidade”.

As idéias que subsidiaram as bases conceituais do estudo são postas a seguir $^{(6)}$ :

- Competência é a “...capacidade de mobilizar diversos recursos cognitivos para enfrentar um tipo de situação" (14).

- “As competências não são elas mesmas saberes, 'savoir-faire’ ou atitudes, mas mobilizam, integram e orquestram tais 'recursos"'(14). 
- O exercício da competência passa por operações mentais complexas, subentendidas por 'esquemas de pensamento'..., que permitem determinar (mais ou menos consciente e rapidamente) e realizar (de modo mais ou menos eficaz) uma ação relativamente adaptada à situação $^{(14)}$.

- "As competências profissionais constroem-se, em formação, mas também ao sabor da 'navegação'... de uma situação de trabalho à outra... ${ }^{n(14)}$;

- Com relação ao savoir y faire (saber e fazer), Perrenoud ${ }^{(14)}$ esclarece que: a) o saber-fazer já existe no estado prático, sem estar sempre ou imediatamente associado a um conhecimento procedimental (porém, se corresponder a um poderá tornar-se simplificado e enriquecido); b) também é uma competência, porém esta pode ser mais ampla do que um saber-fazer e estar mais articulada com os conhecimentos formais; c) um saber-fazer pode funcionar como recurso a ser mobilizado por uma ou mais competências de níveis elevados;

- Geralmente, três elementos complementares são necessários para se descrever uma competência: a) relacionar cada uma delas a uma determinada situação, tarefa, problema; b) identificar os recursos cognitivos utilizados (saberes, técnicas, savoir-faire, atitudes, competências específicas, esquemas motores, de percepção, de avaliação, antecipação e de decisão; c) a natureza dos esquemas de pensamento que permitiram a associação, a mobilização, a orquestração dos recursos utilizados em situação complexa e em tempo real ${ }^{(14)}$; 
- Esses elementos complexos levam a considerar a instabilidade deste terreno, tanto no plano dos conceitos como das ideologias ${ }^{(27)}$;

- As competências constroem-se em função das situações que o indivíduo enfrenta com maior freqüência ${ }^{(27)}$;

- As competências profissionais são privilegiadas, na medida em que as situações de trabalho reproduzem-se dia após dia, em decorrência da rotina e da divisão de tarefas $^{(27)}$;

- "A competência do especialista baseia-se, além da inteligência operária, em esquemas heurísticos ou analógicos próprios de seu campo, em processos intuitivos, procedimentos de identificação e resolução de um certo tipo de problema, que aceleram a mobilização dos conhecimentos pertinentes e subentendem a procura e a elaboração de estratégias de ação apropriadas"(14);

- A perícia nesse processo também supõe “...atitudes e posturas mentais, curiosidade, paixão, busca de significado, desejo de tecer laços, relação com o tempo, maneira de unir intuição e razão, cautela e audácia, que nascem tanto da formação como da experiência,(14);

- Não há transferência ou integração de conhecimentos quando essa mobilização não ocorreu por meio de um treinamento, ou seja, há a necessidade de um acompanhamento pedagógico e didático para que ocorra a integração dos conhecimentos em competências ${ }^{(14)}$;

- "Toda competência está, fundamentalmente, ligada a uma prática social de certa complexidade". Estará ligada a um conjunto de gestos, posturas e palavras contidas numa prática que lhe confere sentido e continuidade $^{(14)}$; 
- As competências obtidas com a formação profissionalizante possuem uma certa generalidade, permitindo ao indivíduo confrontar a prática com situações de trabalho que, a despeito da singularidade de cada um, poderão ser dominadas ${ }^{(27)}$;

- A competência como sendo uma capacidade de agir eficazmente em um determinado tipo de situação, apoiada em conhecimentos, mas sem limitar-se a eles. O conhecimento faz parte de vários recursos cognitivos complementares, isto proporcionará enfrentar uma situação da melhor maneira possível ${ }^{(14)}$;

- A construção de competências está atrelada a formação de esquemas de mobilização dos conhecimentos com discernimento, em prol de uma ação eficaz. Os esquemas de mobilização de diversos recursos cognitivos em uma situação de ação complexa desenvolvem-se e estabilizam na prática. No ser humano não se aplica a programação de esquemas por uma intervenção externa ${ }^{(14)}$;

- O sujeito também não pode construí-los por simples interiorização de um conhecimento procedimental. A construção dos esquemas ocorrem por treinamento de experiências renovadas, ao mesmo tempo redundantes e estruturantes, e isto torna-se mais eficaz quando associado a uma postura reflexiva. O tempo para viver as experiências e a possibilidade de analisá-la é que vai proporcionar este treinamento $^{(14)}$;

- A constituição de competência, além dos conhecimentos que ela mobiliza, atualiza, extrapola ou produz, é também a capacidade de 
encontrar, de reunir, de reconstruir, de reler, até mesmo de reaprender ${ }^{(27)}$;

- Há uma relação indissociável entre transferência e competência, a ponto de dizer que toda competência é transversal, pois ela atravessa várias situações e não se finaliza na situação inicial ${ }^{(27)}$;

- A competência passa pela capacidade do sujeito em mobilizar o todo ou parte de seus recursos cognitivos e afetivos para enfrentar uma família de situações complexas ${ }^{(31)}$;

- A competência é a capacidade de produzir hipóteses, inclusive saberes sociais que ainda não estão "constituídos", são constituíveis a partir dos recursos do sujeito ${ }^{(32)}$;

- "Os professores adeptos da idéia de competência assumem tremendas responsabilidades na escolha de práticas sociais de referência e investem nelas sua própria visão de sociedade, cultura e ação, ainda mais à medida que transmitem conhecimentos ${ }^{(33)}$;

- "Os professores que não se interessam por essa abordagem... irão desprezá-la e ficarão limitados a competências disciplinares consagradas... eles investirão o essencial de sua energia na transmissão de conhecimentos teóricos e métodos”(27);

Os conceitos e idéias que foram apresentados sobre o tema competência sustentaram a análise do conteúdo emitido por alunos e em textos documentais, com a intenção de confrontar os dados à luz destes referenciais.

No que tange a construção das competências voltadas para a prática profissional na Enfermagem, inserimos o conceito de pensamento crítico e competência clínica, vinculando-os a essas construções teóricas. 
Há autores que estudaram e afirmam a correlação entre possuir habilidade de pensamento crítico e exercer a competência clínica, porque "isto significa que a prática competente depende da habilidade de pensar criticamente". Para Watson; Glaser (1980) pensar criticamente envolve “...conhecimentos e atitudes, incluindo atitudes de investigação sobre um problema identificado, a aceitação da evidência para assegurar a veracidade e o conhecimento da natureza e valor das inferências, abstrações e generalizações nos quais os tipos de evidências são mensurados, considerando a precisão e relevância para uma solução lógica" (34). Bradshaw $^{(35)}$ dentre várias colocações destaca que cabe também à definição de "competência clínica como ser capaz de avaliar, planejar, implementar e evoluir o cuidado..." acrescenta que a graduação não tem preparado adequadamente as enfermeiras para o desenvolvimento da competência na prática profissional; e que para definir e determinar competência para a profissão precisa-se ter entendimento claro do propósito da prática de Enfermagem, sendo que isto constitui-se em vários níveis, do geral, do especializado, e outros.

As autoras Benner et $\mathrm{al}^{(36)}$, May et $\mathrm{al}^{(34)}$ contribuem acrescentando que a competência clínica, por sua vez, compreende mais que a habilidade de tomar decisões. Consiste na habilidade de unir conhecimento formal e experiência clínica, além de representar um processo de desenvolvimento cognitivo, psicomotor e afetivo. O terreno é complexo, envolve a capacidade humana de crescer intelectualmente e, na qual, a estrutura de formação escolar está intimamente imbricada. Na verdade está se falando na aplicação da competência de se saber pensar, aprender a aprender e intervir de modo inovador e ético sob diferentes condições operacionais. ${ }^{(6)}$ 
Essas referências que permearam a palavra competência e buscaram explicá-la e contextualizá-la no âmbito do seu desenvolvimento e da sua aplicabilidade sustentaram a análise do discurso dos alunos, sujeitos do estudo, na busca da identificação dos referenciais de competências.

\subsection{Abordagem Metodológica}

Esta pesquisa teve um caráter exploratório-descritivo, numa abordagem qualitativa. As pesquisas exploratórias têm como objetivo proporcionar maior familiaridade com o problema, com vistas a torná-lo mais explícito. As pesquisas descritivas, por sua vez, têm como objetivo a descrição das características de uma determinada população ou fenômeno, ou, então, o estabelecimento de relações entre variáveis ${ }^{(37)}$

Nessa construção, a PRIMEIRA ETAPA do estudo referiu-se à Análise Documental dos Planos de Ensino das disciplinas assistenciais da graduação, tendo por finalidade identificar matrizes de sentido relativas à construção da competência clínica.

Para isto, utilizou-se a técnica da análise documental que é um método indicado nas pesquisas qualitativas com o objetivo de identificar informações em documentos tendo por base as questões ou hipóteses de interesse ${ }^{(38)}$. Para essa análise são considerados documentos todo material escrito que possam ser utilizados como fonte de informação sobre o comportamento humano, incluindo leis, regulamentos, normas, pareceres, cartas, memorandos, entre outras fontes ${ }^{(38)}$.

Segundo Lüdke, André(38) "os documentos constituem uma fonte poderosa de onde podem ser retiradas evidências que fundamentem afirmações e declarações do pesquisador... não são apenas uma fonte de informação 
contextualizada, mas surgem num determinado contexto e fornecem informações sobre esse mesmo contexto".

Nesta pesquisa os documentos tiveram por foco os planos de ensino das disciplinas assistenciais.

A SEGUNDA ETAPA da pesquisa teve como foco o aluno tentando acessar as características identitárias e as representações relativas à aprendizagem e a utilização dos Incidentes Críticos para apreender as representações discentes acêrca de como vivenciaram a aprendizagem das competências clínicas. Nessa etapa utilizou-se das narrativas contidas no questionário (ANEXO B) com os seguintes itens:

- Identificação: idade, sexo;

- Bagagem pregressa: trajetória escolar antes da graduação;

- Trajetória durante a graduação: tempo de graduação, participações em eventos científicos, pesquisas realizadas, estágios extracurriculares, projetos de extensão, participações em conselhos, monitorias;

- Hábitos de vida;

- Autocaracterização: auto-descrição;

- Projetos profissionais.

Sobre as representações relativas à aprendizagem das competências clínicas, para isso os dados requeridos foram:

- O conceito discente sobre competência clínica;

- Apreciações relativas ao ensino/aprendizagem das competências clínicas nas diferentes disciplinas assistenciais; 
- A relação estabelecida pelos estudantes entre a aprendizagem e a percepção do desempenho clínico por parte dos enfermeiros.

Dando seqüência à perspectiva representacional de aprendizagem das competências clínicas o foco complementar foi o Incidente Crítico, como estratégia para sintetizar representações de sentido e projetos de ação de estudantes na interpretação dessa situação dilemática, tendo como questão central a descrição narrativa, segundo a técnica descrita, de uma situação clínica vivida pelo discente.

A Técnica do Incidente Crítico (TIC) é apropriada para obtenção e análise dos dados. Esta técnica contribui para que as lacunas no conhecimento sejam preenchidas, proporcionando base para discussões ou revisão de conteúdos ${ }^{(39)}$.

Nos Estados Unidos no início da década de 40 iniciou-se as primeiras aplicações da TIC, no Brasil nenhum trabalho foi publicado antes de 1971.

Dela Coleta ${ }^{(40)}$, no Brasil, desde 70 vem desenvolvendo estudos preliminares, visando adaptar às nossas condições particulares a TIC, proposta pelo Dr. John Flanagan em 1941, quando participante do Programa de Psicologia da Avaliação da Força Aérea dos Estados Unidos, na II Guerra Mundial ${ }^{(40)}$.

Conforme define Dr. Flanagan"(41), "esta técnica consiste em um conjunto de procedimentos para a coleta de observações diretas do comportamento humano, de modo a facilitar sua utilização potencial na solução de problemas práticos e no desenvolvimento de amplos princípios psicológicos, delineando também procedimentos para a coleta de incidentes observados que apresentem significação especial e para o encontro de critérios sistematicamente definidos".

"Qualquer atividade humana observável que seja suficientemente completa em si mesma para permitir inferências e previsões a respeito da pessoa que executa o ato, é entendida por incidente crítico. Para ser crítico um incidente 
deve ocorrer em uma situação onde o propósito ou intenção do ato pareça razoavelmente claro ao observador e onde suas conseqüências sejam suficientemente definidas para deixar poucas dúvidas no que se refere aos seus efeitos". Com isso pode-se entender o incidente como a ruptura no funcional normal de um sistema(40).

Dentre vários estudos que foram realizados com esta técnica registrou-se alguns que utilizaram este método ${ }^{(42,43,44,45)}$.

O incidente crítico é um método que proporciona a descrição narrativa, com maior número de detalhamento possível, incluindo as intenções e interpretações dos eventos, assim como a cronologia da ação e dos resultados, possibilitando a emergência de domínios e competências clínicas na prática dos sujeitos $^{(36)}$.

Na Técnica do Incidente Crítico no que diz respeito à coleta de dados, conforme afirmam Polit; Hungler ${ }^{(46)}$, pode-se utilizar entrevistas semiestruturadas, questionários e a observação.

Optou-se por utilizar o método através de descrições narrativas registradas pelos sujeitos em questionários, os registros escritos, são detalhados e citados à medida que eles aconteceram.

Como método são preconizados sete passos na utilização da $\operatorname{TIC}^{(40)}$.

1을eterminação dos objetivos:

Faz-se preliminarmente uma minuciosa descrição das "tarefas e operações (atividades) executadas pelos ocupantes do cargo em estudo". No estudo esta etapa não foi descrita desta forma, pois a prática discente já pressupõe atividades previamente estabelecidas. 
$2^{\circ}$ Elaboração das questões a serem apresentadas aos sujeitos e que neste estudo, agregam:

$\mathrm{B}_{1}$ - $\mathrm{O}$ contexto da situação, como: período do dia, profissionais envolvidos, condições de trabalho, disciplina que estava cursando, unidade ou enfermaria onde ocorreu a situação, ano da graduação que estava cursando.

B2 - Uma detalhada descrição do que aconteceu durante o processo de ensino-aprendizagem que influenciaram na experiência do incidente crítico (situação).

B3 - Por que o incidente foi crítico para você?

B4 -Como você se comportou nessa situação?

B5 - O que você sentiu durante e após o incidente (situação)?

B6 - O que você avalia como tendo sido mais trabalhoso na situação?

B7 - O que você avalia como tendo gerado maior satisfação na situação?

3ํㅡㄹ Delimitação da população ou amostra, que nesta pesquisa foi constituída por todos os alunos do $4^{\circ}$ ano que concordaram em participar, ou seja, os 29 graduandos.

4ํㅡㄹ Coleta dos incidentes críticos:

Os acontecimentos (situação) relevantes e com mínimos detalhes deverão ser registrados, relatando os incidentes independente do desfecho. $O$ estudo levantou acontecimentos clínicos ocorridos nos estágios que foram registrados sistematicamente pelos alunos. Isto ocorreu ao mesmo tempo com os alunos, que na presença da pesquisadora responderam individualmente os questionários. 
Cabe esclarecer que os dados referidos tiveram um caráter retroativo, possibilitando rememorizar eventos significativos ocorridos no decorrer da formação clínica.

5ํAnálise de conteúdo dos incidentes críticos coletados.

6ํㅡㄹ Agrupamento dos comportamentos críticos em categorias:

Essas tapas de análise e agrupamento pressupõem um investimento subjetivo na atribuição de sentidos aos conteúdos representacionais expressos pelos estudantes. Foram elaborados espaços representacionais que tiveram por finalidade caracterizar as construções ideativas relativas as questões do estudo. Essa elaboração teve por base os pressupostos de Bardin $^{(47)}$ a serem referidos posteriormente.

$7^{0}$ ํ Levantamento das freqüências dos comportamentos ditos como positivos e/ou negativos (desfecho). Essa etapa não foi referida no estudo, pela perspectiva qualitativa, agregando as discussões desses comportamentos.

Para obtenção dos dados relativos ao IC utilizou-se o questionário elaborado por meio do Projeto AMICAE (Archieving Methods of Intra-Professional Consensus, Assesment and Evaluation) construído por Deborah Gordon e Patrícia Benner em 1980, enfermeiras que trabalharam neste projeto com a participação de sete Escolas de Enfermagem e cinco hospitais da região de São Francisco ${ }^{(36)}$.

Utilizou-se também as recomendações contidas no instrumento de (Waldow, Lopes, Meyer ${ }^{(39)}$; Ide, De Domenico, Gatto $\left.{ }^{(48)}\right)$; incluindo-se algumas adaptações, principalmente quanto a forma de efetuar os registros isto resultou o INSTRUMENTO DE COLETA DE DADOS, intitulado "O INCIDENTE CRÍTICO" (ANEXO C). 


\subsection{Local do estudo}

O Curso de Graduação em Enfermagem está vinculado à Faculdade de Medicina - UNESP - no interior do Estado de São Paulo. Esse curso de graduação foi criado em 1989, transformando-se em Departamento da Faculdade de Medicina em 1999.

A primeira turma foi formada em 1992 e a XIII será formada em 2004. No momento tramita a solicitação para a criação da Faculdade de Enfermagem.

Historicamente temos a referência que em 1985 a Faculdade de Medicina, ouvida a Congregação, decidiu solicitar a abertura do Curso de Graduação em Enfermagem.

Para sua organização contou-se com a assessoria e colaboração de docentes representantes da Escola de Enfermagem da Universidade de São Paulo e docentes representantes dos cursos de Fisioterapia e Terapia Ocupacional da Universidade Federal de São Carlos.

Em 1989 iniciou-se as atividades do Curso de Enfermagem da Faculdade de Medicina de Botucatu-UNESP. Nesta mesma época deu início também ao processo para solicitação da criação do Departamento de Enfermagem, que foi aprovada somente em julho de 1999.

A criação do Curso de Enfermagem ofereceu cobertura a um distrito geopolítico-educacional amplo, onde até então não existia Escola de Enfermagem pública, com ensino gratuito.

O objetivo do Curso vem sendo formar o profissional enfermeiro capacitado para desenvolver atividades inerentes às funções que the são conferidas através da Lei do Exercício Profissional nº 7498/86, além de exercer plenamente seu papel de cidadão de forma crítica, consciente, como sujeito e agente de 
transformações, para a melhoria das condições de trabalho, saúde e vida na sociedade a que pertence.

O curso, com duração mínima de quatro anos, em período integral, oferece 30 vagas por ano. Os alunos podem receber incentivos, como bolsas de iniciação científica, monitoria e o Programa de Apoio ao Estudante (PAE).

Ainda no atual currículo, no primeiro ano o aluno cursa disciplinas do ciclo básico, que são oferecidas pelo Instituto de Biociências da UNESP. Outras disciplinas pré-profissionalizantes são ministradas por outros departamentos da FM (Faculdade de Medicina). A partir do segundo ano inicia-se as disciplinas profissionalizantes.

Atualmente, o corpo docente do departamento de enfermagem é constituído por 26 professores enfermeiros e 2 professores nutricionistas, perfazendo um total de 28 docentes que atuam na área profissionalizante. Estes professores encontram-se envolvidos em projetos de pesquisa, ensino e extensão e na sua totalidade inseridos em programas de pós-graduação.

O Departamento de Enfermagem é composto de:

- 2 professores adjuntos;

- 17 professores doutores;

- 19 professores assistentes.

O projeto político pedagógico do Curso de Enfermagem tem como pressuposto formar alunos com o perfil profissional considerando:

O Enfermeiro como um cidadão crítico, consciente de seu papel profissional na sociedade, competente para o exercício das atribuições regulamentadas em lei. 
São compromissos do Enfermeiro:

- Atuar nos diferentes campos de trabalho embasado numa formação generalista.

- Assistir o indivíduo, família e comunidade, atuando nos diferentes cenários da prática profissional nos diferentes níveis de atenção à saúde.

- Ter visão ética, política e crítica da realidade nacional, regional e local de saúde, associada ao conhecimento técnico-científico.

- Integrar a equipe de saúde, comprometendo-se com o trabalho interdisciplinar competente, com visão integral do ser humano.

- Planejar e implementar programas de formação e qualificação contínua dos trabalhadores de enfermagem e de saúde.

- Planejar e implementar programas de educação e promoção à saúde, considerando especificidades dos diferentes grupos sociais e dos distintos processos de vida, saúde, trabalho e adoecimento.

- Adotar os princípios de Universalização, Eqüidade e Integralidade da assistência à saúde e os referenciais bioéticos de autonomia, beneficência e não maleficência e justiça em todo o exercício profissional, promovendo a humanização da assistência.

- Coordenar a equipe de enfermagem, responsabilizando-se pelo planejamento sistemático da assistência de enfermagem.

- Assumir funções assistenciais, gerenciais, de ensino e de investigação científica, aplicando conhecimentos na qualificação da prática profissional. 
- Interferir na dinâmica do trabalho institucional, reconhecendo-se como agente desse projeto.

- Participar de entidades representativas da categoria dos movimentos sociais na área da saúde tendo como perspectivas as transformações necessárias para uma sociedade saudável.

A organização curricular até o momento está construída sob bases de uma grade inflexível, linear, com carga horária elevada e pouquíssima "área verde". A coordenação do Curso de Enfermagem, vem trabalhando junto ao Conselho de Curso de Graduação, com o objetivo de implementar um novo projeto pedagógico, que atenda à LDB (Leis de Diretrizes Básicas) ${ }^{(49)}$ e o desejo do corpo docente e discente. Para tanto as diretrizes que foram discutidas consensualmente até o momento estão apresentadas abaixo:

- Mudança curricular gradual, flexível e contínua.

- Integração precoce do aluno no campo de atuação profissional.

- Investir na integração contínua com o ciclo básico.

- Rever a grade curricular já existente, inserindo o estágio obrigatório.

- Investir na integração docente/assistencial para garantir campos de estágio.

- Ampliar o leque de opções para disciplinas optativas.

- A base de organização curricular deve seguir os princípios de:
a) cuidados fundamentais
b) criança
c) mulher
d) adulto/idoso
e) cuidados especializados 
Acrescenta-se a necessidade de atender a Resolução do CNE/CES n. $3^{(16)}$ e o Conselho de Curso da Graduação trabalha atualmente para implementação de mudanças curriculares, também baseadas em competências. Esses dados foram extraídos de documentos contidos no Projeto Político-Pedagógico( ${ }^{(50)}$.

\subsection{Sujeitos da pesquisa}

O estudo foi desenvolvido junto à estudantes do $4^{\circ}$ ano ( $8^{\circ}$ semestre), em processo de conclusão do curso de graduação em Enfermagem, os que aceitaram constituir o grupo. Cabe salientar que a totalidade dos graduandos participou da pesquisa.

\subsection{Aspectos éticos}

O estudo foi desenvolvido após a ciência e aprovação do Conselho do Curso de Graduação em Enfermagem e dos docentes responsáveis pelas disciplinas profissionalizantes envolvidas.

Posteriormente o projeto foi enviado ao Comitê de Ética em Pesquisa do Hospital das Clínicas de Botucatu - UNESP, com estes consentimentos recebendo aprovação conforme Processo OF. 468/2002-CEP (ANEXO D).

Após este trâmite ficou assegurado aos alunos que aceitassem participar, a manutenção do sigilo e anonimato de sua identidade, além do direito de desistir em qualquer fase do estudo, sem qualquer prejuízo no seu aprendizado. 
Tal participação efetivou-se após a assinatura do Termo de Consentimento Livre e Esclarecido, conforme recomenda a Resolução 196/1996 do Ministério da Saúde ${ }^{(51)}$. (ANEXO A), seguindo as orientações do Comitê de Ética em Pesquisa da Faculdade de Medicina de Botucatu-UNESP.

\subsection{Coleta de dados e Instrumento}

Para apreender manifestações de como os estudantes foram constituindo suas competências e como representaram tais construções na interface com o processo de formação, utilizou-se um questionário conforme referido a seguir:

- Introdução, visando localizar o objeto de estudo, assim como motivar a participação individual (ANEXO B).

- 1a Parte: Caracterização no que se referiu ao perfil discente; (ANEXO B).

- $2^{a}$ Parte: Percepção do aluno acerca das competências ensinadas e desenvolvidas no decorrer da graduação; (ANEXO B).

- $3^{\text {a }}$ Parte: Construção do Incidente Crítico, para a descrição de uma situação clínica vivida pelo aluno, conforme enunciado (ANEXO C). 


\subsection{Análise dos dados}

Os dados obtidos por meio dos questionários, com os registros de autorelato onde as narrativas revelaram os conteúdos ideativos, foram analisados segundo esquemas representacionais, a partir da análise de conteúdo de $\operatorname{Bardin}^{(47)}$ sendo este método desenvolvido a partir de uma lógica de similaridade.

Segundo palavras de Bardin ${ }^{(47)}$, a análise de conteúdo consiste "Um conjunto de técnicas de comunicação visando obter, por procedimentos sistemáticos e objetivos de descrição do conteúdo das mensagens, indicadores (quantitativos ou não) que permitam a inferência de conhecimentos relativos às condições de produção/reprodução destas mensagens".

Para Bardin, a especificidade analítica está constituída pela relação existente "a superfície dos textos, descrita e analisada (pelo menos alguns elementos característicos) e os fatores que determinam estas características, deduzidos logicamente,(47). Ao se realizar a análise busca-se uma correspondência entre as estruturas semânticas ou lingüísticas (significantes) e as estruturas psicológicas ou sociológicas (significados) dos enunciados ${ }^{(47,52)}$. A intenção do analista é dupla: “...compreender o sentido da comunicação (como se você, o receptor normal), mas também e principalmente desviar o olhar para uma outra significação, uma outra mensagem entrevista através ou ao lado da mensagem primeira"(47).

As palavras e suas significações são trabalhadas pelo pesquisador no sentido de conhecer o que está por trás das palavras analisadas, “...é uma busca de outras realidades através das mensagens"(47). 
O método revela-se por três fases que são: a pré-análise; a descrição analítica e a interpretação inferencial. Na pré-análise o material das entrevistas, no caso dos relatos através da narrativa, serão transcritos e submetidos à leitura flutuante, privilegiando o sentido global dos discursos ${ }^{(47)}$. No estudo esta fase foi realizada exaustivamente sobre as narrativas registradas detalhadamente pelos alunos, nos questionários.

Posteriormente, na fase de descrição analítica, prossegue-se com o recorte e escolha das unidades de registro, elegendo-as e codificando-as mediante a convergência com o fenômeno ${ }^{(47)}$. Assim, as unidades temáticas serão classificadas sob um título genérico, a partir de um grupo de elementos. As categorias obtidas com esse processo possuirão relações, podendo proporcionar o aprofundamentos de idéias, propor inferências e adiantar as interpretações do conteúdo manifesto, ou mesmo do conteúdo latente ${ }^{(47)}$.

Com isso, os dados "brutos" foram estruturados pelo processo de categorização, onde do isolamento dos elementos (unidades) a classificação, propondo a organização das mensagens, sendo possível dar significado e assim organizar dados. As relações foram determinadas propiciando interpretações.

Para a análise documental o presente estudo também pautou-se nos pressupostos da análise de conteúdo, considerando as diferenças essenciais apontadas por Bardin ${ }^{(47)}$. 


\section{APRESENTAÇÃO DOS RESULTADOS E ANÁLISE DOS DADOS}




\section{APRESENTAÇÃO DOS RESULTADOS E ANÁLISE DOS DADOS}

\subsection{As intenções educativas e o ensino de competências clínicas: o planejamento disciplinar em destaque.}

É possível considerar que a qualificação da prática educativa em Enfermagem passe pela compreensão aprofundada dos processos que sustentam sua configuração, dependentes da complexa interação de múltiplos fatores que se articulam nas situações de ensino, incluindo: tipo de atividade metodológica, aspectos materiais da situação, estilo do professor, relações sociais, conteúdos culturais, dentre outros. ${ }^{(15)}$ Nesse estudo, dentre outras perspectivas, o marco de análise privilegiado teve por foco as seqüências de disciplinas que embasam a abordagem clínica, incluindo a análise dos objetivos propostos, dos conteúdos elencados e das estratégias preconizadas para a implementação desses conteúdos que têm a clínica como referência.

Tendo por baliza os planos de ensino, foi possível identificar, pela análise documental, uma intenção consensual de capacitação, pautada na valorização da prática, em seu conjunto de saberes prévia e discursivamente apresentados, a serem posterior e intensivamente utilizados na prática, em exercícios técnicos, desenvolvidos em situações controladas, tendo por foco seqüências de atividades que gradativamente vão se ampliando sem que a totalidade da formação clínica se manifeste, pelo menos como espaço formalizado. A performance discente na repetição em campo dos conteúdos da sala de aula seria o controle de resultado a pautar a avaliação enquanto peça chava para perpetuar o modelo de formação 
preconizado pelo Curso. Evidências dessa representação encontram-se expressas a seguir.

Quadro 1 - A disposição das disciplinas assistenciais na estrutura curricular da graduação. São Paulo, 2004

\begin{tabular}{|c|c|c|}
\hline Disciplinas & Ano/Semestre & Carga Horária \\
\hline Introdução à Enfermagem & $1^{0} / 2^{0}$ & Total: $45 \mathrm{~h}(\mathrm{~T}=28 \mathrm{~h} / \mathrm{P}=17 \mathrm{~h})$ \\
\hline Fundamentos de Enfermagem & $2^{0} / 1^{0}$ & Total: $330 \mathrm{~h}(\mathrm{~T}=180 \mathrm{~h} / \mathrm{P}=150 \mathrm{~h})$ \\
\hline Enfermagem Médico-Cirúrgica & $2^{0} / 2^{0}$ & Total: $512 \mathrm{~h}(T=121 \mathrm{~h} / \mathrm{P}=376 \mathrm{~h})$ \\
\hline Enfermagem em Centro-Cirúrgico & $3^{\circ} / 1^{\circ}$ & Total: $240 \mathrm{~h}(\mathrm{~T}=120 \mathrm{~h} / \mathrm{P}=120 \mathrm{~h})$ \\
\hline $\begin{array}{l}\text { Enfermagem em Doenças } \\
\text { Transmissíveis }\end{array}$ & $3^{0} / 1^{0}$ & Total: $240 \mathrm{~h}(\mathrm{~T}=120 \mathrm{~h} / \mathrm{P}=120 \mathrm{~h})$ \\
\hline Enfermagem Pediátrica & $3^{\circ} / 2^{\circ}$ & Total: $240 \mathrm{~h}(\mathrm{~T}=120 \mathrm{~h} / \mathrm{P}=120 \mathrm{~h})$ \\
\hline $\begin{array}{l}\text { Enfermagem Ginecológica, } \\
\text { Obstétrica e Neonatal }\end{array}$ & $3^{0} / 2^{0}$ & Total: $300 \mathrm{~h}(T=150 \mathrm{~h} / \mathrm{P}=150 \mathrm{~h})$ \\
\hline Enfermagem Psiquiátrica & $4^{0} / 1^{0}$ & Total: $240 \mathrm{~h}(\mathrm{~T}=120 \mathrm{~h} / \mathrm{P}=120 \mathrm{~h})$ \\
\hline $\begin{array}{l}\text { Enfermagem Preventiva e } \\
\text { Comunitária }\end{array}$ & $4^{\circ} / 1^{0}$ & Total: $240 \mathrm{~h}(\mathrm{~T}=60 \mathrm{~h} / \mathrm{P}=180 \mathrm{~h})$ \\
\hline
\end{tabular}

Esses dados preliminares evidenciaram aspectos relevantes da intenção educativa que sustentaria o Curso.

É possível considerar que a dimensão assistencial seria a atividade de formação privilegiada uma vez que ocupa aproximadamente $2500 \mathrm{~h}$ das $4600 \mathrm{~h}$ da graduação, sendo antecipada por um ciclo básico voltado à sustentação das bases teóricas que Ihe daria sustentação, tendo por foco conteúdos hegemonicamente biológicos aproximadamente 900h, bem como, por ser um conjunto de disciplinas 
que compõem-se ao longo da graduação, teoricamente a perspectiva social, psicológica, metodológica, histórica, por aproximadamente $720 \mathrm{~h} .{ }^{(50)}$

Por outro lado, a clínica antecede a Administração em Enfermagem com aproximadamente $480 \mathrm{~h}$, presente no último semestre do $4^{\circ}$ ano, parecendo retratar uma perspectiva de formação que consideraria necessário primeiro aprender a cuidar para depois aprender a administrar. Essa disposição evidenciaria uma concepção de formação que considera avulsos os processos como complementares, não reconhecendo a especificidade do pensamento/ação clínica e administrativa, trazendo repercussões complexas na formação do aluno conforme evidências a serem posteriormente apresentadas.

É possível considerar também que a capacitação clínica ocorreria de forma fragmentada, obedecendo aos critérios "domínio técnico" e "clínicas específicas", apresentados em espaços e tempos separados, dispostos para fundamentar abordagens teórico-práticas isoladas por disciplinas. A lógica interna de cada uma delas será o referencial básico para a seleção e articulação dos conteúdos; a prioridade básica seriam as matérias e sua aprendizagem em si. A noção de integração no sentido de uma clínica ampliada, integrada, não foi identificada.

Caberia identificar ainda uma meta gradual de formação que teria por início dispositivos de enunciação da prática, de sua inserção no macro contexto; a explicitação de limites ético-jurídicos como bagagem necessária para a iniciação prática que gradativamente também evoluiria do procedimento "básico" e dissociado ao cuidado direto ampliado, sustentado e algumas vezes sistematizado segundo referências disciplinares específicas. Formas organizativas passíveis de encadear e articular as diferentes abordagens parecem estar ausentes dessa seqüência. 
Nesse sentido, nem mesmo as Diretrizes Curriculares ${ }^{(16)}$ estariam sendo consideradas uma vez que as áreas temáticas sugeridas ainda não se fazem presentes. Assim, a "Assistência de Enfermagem em nível individual e coletivo prestada à saúde da criança, ao adolescente, ao adulto, à mulher, e ao idoso"(16) seriam conteúdos implícitos às disciplinas, sem que as aproximações necessárias à conformação dos macro temas se fizessem presentes, evidenciando uma intenção de formação aquém até mesmo dessas balizas.

Como denominador comum à todas as disciplinas é possível identificar uma alocação de tempo e de espaço pré determinada, viabilizada em dois tempos: o tempo da sala de aula e o tempo da prática, em laboratório e/ou campo. A experiência prática sempre ocupa minimamente a metade da carga horária total das disciplinas, sendo que em duas delas (Enfermagem Médico-Cirúrgica e Enfermagem Preventiva e Comunitária) equivale a três vezes a carga teórica.

Serão apresentados os componentes dos planos de ensino, quanto aos objetivos relacionados às capacidades que se pretende desenvolver e os conteúdos, segundo sua tipologia. 
Quadro 2 - Componentes dos planos de ensino das disciplinas assistenciais: Introdução à Enfermagem, Fundamentos de Enfermagem e Enfermagem Médico-Cirúrgica. São Paulo, 2004

\begin{tabular}{|c|c|c|}
\hline Disciplinas & $\begin{array}{c}\text { Objetivos } \\
\text { (relacionados às capacidades que se } \\
\text { pretende desenvolver) }\end{array}$ & $\begin{array}{c}\text { Conteúdos } \\
\text { (segundo sua tipologia) }\end{array}$ \\
\hline $\begin{array}{l}\text { 1. INTRODUÇÃO Á } \\
\text { ENFERMAGEM }\end{array}$ & $\begin{array}{l}\text { - Conhecimento do processo } \\
\text { saúde/doença/instituição hospitalar } \\
\text { (Cog) } \\
\text { - Identificação dos componentes da } \\
\text { equipe de saúde (Cog) } \\
\text { - Conhecimento sobre técnica em } \\
\text { enfermagem (Mot) } \\
\text { - Conhecimento sobre o Processo de } \\
\text { Enfermagem (Cog) } \\
\text { - Análise sob perspectivas ética e legal } \\
\text { (Cog) } \\
\text { - Definição das entidades de classe } \\
\text { (Cog) } \\
\text { - Definição dos campos de atuação do } \\
\text { enfermeiro (Cog) }\end{array}$ & $\begin{array}{l}\text { - Apresentação de dados históricos (das } \\
\text { civilizações antigas à Enfermagem } \\
\text { contemporânea) (F) } \\
\text { - Apresentação de dados sobre assistência em } \\
\text { saúde (definições saúde-doença; instituição; } \\
\text { recursos humanos; medidas de biossegurança } \\
\text { com técnicas; sinais vitais) (F + } \mathrm{P}^{-} \text {) } \\
\text { - Apresentação das Teorias de Enfermagem } \\
\text { (conceitos de teoria/processo de enfermagem, } \\
\text { método científico) (C) } \\
\text { - Apresentação dos Instrumentos Básicos da } \\
\text { Enfermagem (C) } \\
\text { - Apresentação dos códigos normativos (ético- } \\
\text { legal; entidade de classe; direitos dos pacientes) } \\
\text { (C + A) } \\
\text { - Reconhecimento de um campo (visita a asilo) (F) }\end{array}$ \\
\hline $\begin{array}{l}\text { 2. FUNDAMENTOS } \\
\text { DE ENFERMAGEM }\end{array}$ & $\begin{array}{l}\text { - Retomada de aspectos ético-legais } \\
\text { (Cog) } \\
\text { - Relativos à análise do processo de } \\
\text { hospitalização (doente, da equipe) } \\
\text { (Cog) } \\
\text { - Noções de infecção hospitalar e } \\
\text { medidas de biossegurança(Cog) } \\
\text { - Atendimento de primeiros socorros } \\
\text { (Cog/Mat) } \\
\text { - Avaliação clínica do adulto(Cog) } \\
\text { - Princípios gerais para administração } \\
\text { de medicamentos (Cog) } \\
\text { - Necessidades básicas (Cog) } \\
\text { - Cuidados com pele e feridas (Cog) } \\
\text { - Prestação de cuidados } \\
\text { sistematizados (Cog) } \\
\text { - Cuidados com o corpo após a morte } \\
\text { (Cog) } \\
\text { - Procedimentos relativos à medidas de } \\
\text { biossegurança(Mot) } \\
\text { - Transporte do acidentado (Cog) } \\
\text { - Procedimentos com preparo de } \\
\text { medicação (Mot) } \\
\text { - Procedimentos relativos às } \\
\text { necessidades básicas afetadas(Mot) } \\
\text { - Realização de curativos (Mot) }\end{array}$ & 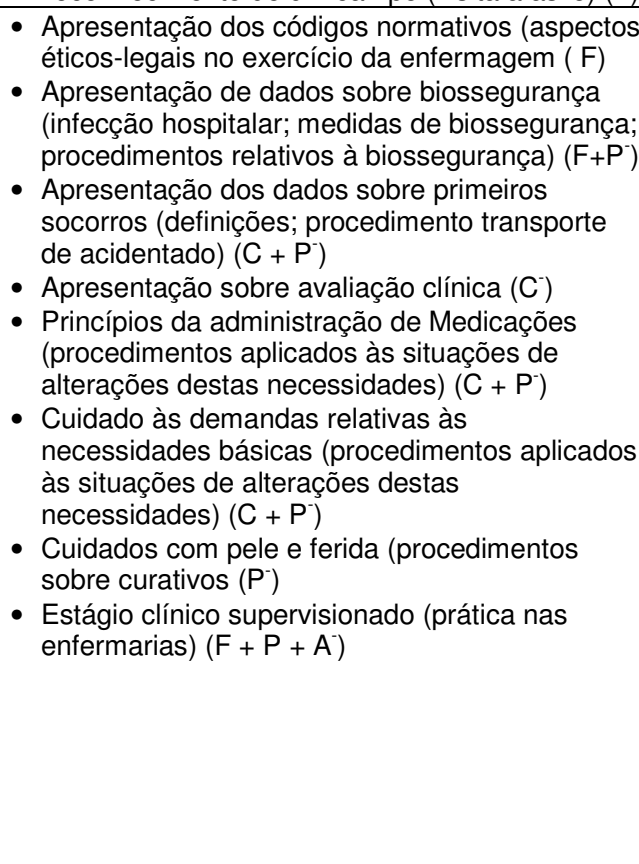 \\
\hline $\begin{array}{l}3 \text { - ENFERMAGEM } \\
\text { MÉDICO- } \\
\text { CIRÚRGICA }\end{array}$ & $\begin{array}{l}\text { - Fundamentos sistematizados da } \\
\text { abordagem clínica ao adulto e idoso } \\
\text { em diferentes situações clínica e } \\
\text { cirúrgica (processo de enfermagem) } \\
\text { (Cog) } \\
\text { - Introduzir a linguagem fisiopatológica } \\
\text { (Cog) } \\
\text { - Realização de procedimentos } \\
\text { especializados (Mot) } \\
\text { - Prática sistematizada (Mot) }\end{array}$ & $\begin{array}{l}\text { - Processo de cuidar (institucionalização; família; } \\
\text { processo de enfermagem; avaliação clínica; } \\
\text { operacionalização - SAE) (C+P+A) } \\
\text { - Conteúdo básico adulto e idoso (equilíbrio } \\
\text { hidroeletrolítico; equilíbrio ácido-base; } \\
\text { radioterapia; geriatria; o paciente cirúrgico (C+P) } \\
\text { - Conteúdo especializado teórico-prático em } \\
\text { laboratório de enfermagem (gasometria, PVC; } \\
\text { ECG; suporte avançado de vida; drenos; } \\
\text { aspiração, exame físico) }\left(C+\mathrm{P}^{-}\right) \\
\text {- Estágio clínico/enfermarias locais: clínica } \\
\text { médica, neurologia, vascular, ortopedia, } \\
\text { gastrocirurgia, ambulatório de hipertensão } \\
\text { (enfermidades em médico-cirúrgica; } \\
\text { operacionalização da SAE) (C + P + A) }\end{array}$ \\
\hline LEGENDA & $\begin{array}{l}\text { (Cog) cognitivas } \\
\text { (Mot) Motoras } \\
\text { (Ins) de inserção e atuação profissional } \\
\text { (Eq/Aut) equilíbrio e autonomia } \\
\quad \text { (afetivas) } \\
\text { (Rel) de relação interpessoal } \\
\end{array}$ & $\begin{array}{l}\text { (F) Factuais } \\
\text { (P) Procedimentais } \\
\text { (C) Conceituais } \\
\text { (A) Atitudinais } \\
\text { (-) significa que não contém todas as etapas } \\
\text { propostas na aceitação } \\
\end{array}$ \\
\hline
\end{tabular}


Tendo como referência, agora as seqüências disciplinares e os componentes dos planos de ensino, é possível identificar uma construção de sentido tendo por base:

- Uma introdução à profissão que, além de curta, divide sua carga horária com prática descontextualizada, já delimitando uma ênfase procedimental;

- Uma iniciação profissional precoce, considerando a ausência de mediações entre as disciplinas básicas e a prática, em laboratório e ou campo. Não se evidencia, na estrutura curricular, tempo e investimentos no sentido de promover aproximações, sínteses, reformulações, proposição de problemas, busca de outras informações elaboração de conclusões, generalizações, dentre outras formas de ensinar potencializadoras de pontes cognitivas entre conteúdos complementares. Essa iniciação também seria precoce porque algumas atividades, antecederiam conteúdos específicos, evidenciando possibilidades do fazer esvaziado de sentido, uma atuação além do possível (banho em UTI, sinais vitais sem correlações fisio ou fisiopatológicas, dentre outras técnicas em si mesmos);

- Uma seqüência Fundamentos de Enfermagem e Enfermagem MédicoCirúrgica aparentemente direcionada à repetição técnica, ocupando significativa carga horária do curso, antecedendo às disciplinas específicas. É possível identificar uma intenção de torná-las propedêuticas às demais, voltadas a uma capacitação técnica precursora de competências específicas. 
Nessa formulação, a área temática Saúde do Adulto não se evidencia na medida em que teoricamente privilegia uma prática assistencial pautada em eventos mórbidos.

- Uma seqüência de disciplinas específicas, cada uma delas introduzindo o aluno em nichos peculiares de formação, transmitindo um "novo" saber-fazer já construído e

- A ausência de investimentos relativos tanto aos conteúdos optativos quanto ao estágio curricular enquanto espaço privilegiado para: a vinculação discente à experiências clínicas significativas anterior, além de promover aproximações diferenciadas com o mercado de trabalho;

- A validação de projetos assistenciais próprios, promovendo a atuação criativa; a experimentação da coordenação do processo de cuidar enquanto iniciativa potencializadora do desenvolvimento da competência relativa ao julgamento e à tomada de decisão clínica, considerando o contexto de prática, as interações intra e interprofissionais e o conjunto de doentes/usuários sob sua responsabilidade; e o reconhecimento das especificidades; entre os processos de cuidar (na prática dual e na coordenação) e de administrar, considerando a dinâmica de trabalho institucional, ambos com referenciais teóricas e expressões metodológicas operacionais próprias: $:^{(53)}$

Essa cultura de formação repete uma tradição prática que se explicita na formulação dos objetivos, na seleção dos conteúdos e nas estratégias de ensino, 
incluindo os critérios de avaliação, conforme os dados referidos a seguir para

disciplinas que completam o grupo de assistenciais.

Quadro 3 - Componentes dos planos de ensino das disciplinas assistenciais: Enfermagem em Centro Cirúrgico, Enfermagem em Doenças Transmissíveis. São Paulo, 2004

\begin{tabular}{|c|c|c|}
\hline Disciplinas & $\begin{array}{c}\text { Objetivos } \\
\text { (relacionados às capacidades que se } \\
\text { pretende desenvolver) }\end{array}$ & $\begin{array}{c}\text { Conteúdos } \\
\text { (segundo sua tipologia) }\end{array}$ \\
\hline $\begin{array}{l}\text { 4. ENFERMAGEM } \\
\text { EM CENTRO - } \\
\text { CIRÚRGICO }\end{array}$ & $\begin{array}{l}\text { - Planejamento em C.C. (Cog) } \\
\text { - SAEP perioperatório (Cog) } \\
\text { - Circular S.0 (comunicação } \\
\text { interpessoal / registro) (Cog) } \\
\text { - Procedimentos anestésicos (Cog) } \\
\text { - Riscos químicos e físicos (Cog) } \\
\text { - Dor pós-operatório (Cog) } \\
\text { - Atuar como circulante (Mot) } \\
\text { - Apoio aos procedimentos } \\
\text { anestésicos(Mot) } \\
\text { - Instrumentação cirúrgica (Mot) } \\
\text { - Relacionamento interpessoal (Rel) }\end{array}$ & $\begin{array}{l}\text { - Apresentação (Dados históricos) (F) } \\
\text { - Conceitos sobre assistência em CC: } \\
\text { (Classificação; Terminologia; Planejamento } \\
\text { C.C.; Sala de recuperação; Central de Material } \\
\text { Infecção em C.C.) (C) } \\
\text { - Noções de Anestesia (C) } \\
\text { - Perioperatório (SAEP) (C) } \\
\text { - Comunicação Interpessoal (A) } \\
\text { - Instrumentação Cirúrgica (o procedimento)(C+P) } \\
\text { - Riscos no Trabalho } \\
\text { (Medidas de biossegurança)(C + P) } \\
\text { - Assistência de Enfermagem no Tratamento da } \\
\text { dor (C) }\end{array}$ \\
\hline $\begin{array}{l}\text { 5. ENFERMAGEM } \\
\text { EM DOENÇAS } \\
\text { TRANSMISSÍVEIS }\end{array}$ & $\begin{array}{l}\text { Cognitivas: } \\
\text { - Integração de conhecimentos das } \\
\text { disciplinas de imunologia e } \\
\text { microbiologia (Cog) } \\
\text { - Novos conhecimentos de doenças } \\
\text { transmissíveis para os níveis } \\
\text { primário, secundário e terciário } \\
\text { (Cog) } \\
\text { - Processo de transmissão das } \\
\text { doenças transmissíveis (Cog) } \\
\text { - Discutir e reconhecer conceitos nas } \\
\text { doenças causadas por vírus, } \\
\text { bactérias, fungos e protozoários } \\
\text { (Cog) } \\
\text { - Prestar assistência de Enfermagem } \\
\text { sistematizada aplicando } \\
\text { conhecimento do processo de } \\
\text { Enfermagem (Cog) } \\
\text { - Aplicar os conhecimentos de } \\
\text { medida de proteção e segurança } \\
\text { (isolamento, precauções universais } \\
\text { e biossegurança) (Mot) }\end{array}$ & $\begin{array}{l}\text { - Fundamentação em doenças transmissíveis: } \\
\text { (Fatores de predisposição de doenças } \\
\text { transmissíveis; Medidas de segurança; } \\
\text { Mecanismos no processo de transmissão de } \\
\text { doença; Terminologias específicas; (C) } \\
\text { - Doenças causadas por vírus, bactérias e fungos } \\
\text { (Enfermidades; Assistência de Enfermagem) (C) } \\
\text { - Abordagem de aspectos epidemiológicos } \\
\text { (Infecção hospitalar; Doenças Transmissíveis)(C) } \\
\text { - Estágio Clínico Enfermarias(C + P + A) } \\
\text { - (doenças transmissíveis e dermatológicas) (C) }\end{array}$ \\
\hline LEGENDA & $\begin{array}{l}\text { (Cog) cognitivas } \\
\text { (Mot) Motoras } \\
\text { (Ins) de inserção e atuação profissional } \\
\text { (Eq/Aut) equilíbrio e autonomia } \\
\quad \text { (afetivas) } \\
\text { (Rel) de relação interpessoal }\end{array}$ & $\begin{array}{l}\text { (F) Factuais } \\
\text { (P) Procedimentais } \\
\text { (C) Conceituais } \\
\text { (A) Atitudinais } \\
\text { (-) significa que não contém todas as etapas } \\
\text { propostas na aceitação }\end{array}$ \\
\hline
\end{tabular}


Quadro 4 - Componentes dos planos de ensino das disciplinas assistenciais: Enfermagem Pediátrica, Enfermagem Ginecológica, Obstétrica e Neonatal. São Paulo, 2004

\begin{tabular}{|c|c|c|}
\hline Disciplinas & $\begin{array}{c}\text { Objetivos } \\
\text { (relacionados às capacidades que se } \\
\text { pretende desenvolver) }\end{array}$ & $\begin{array}{c}\text { Conteúdos } \\
\text { (segundo sua tipologia) }\end{array}$ \\
\hline $\begin{array}{c}6 \text { - ENFERMAGEM } \\
\text { PEDIÁTRICA }\end{array}$ & $\begin{array}{l}\text { - Abordar aspectos teóricos sobre } \\
\text { Enfermagem Pediátrica (Cog) } \\
\text { - Prestar cuidados integrais à criança } \\
\text { e família (Cog) } \\
\text { - Atuar nos diferentes níveis de } \\
\text { assistência (Cog) } \\
\text { - Propor investigação científica(Cog) } \\
\text { - Abordar aspectos práticos sobre } \\
\text { Enfermagem Pediátrica (Cog) }\end{array}$ & $\begin{array}{l}\text { - Apresentação dos aspectos gerais (Conceitos } \\
\text { introdutório; Aspectos epidemiológicos na } \\
\text { infância/ adolescência; do Estrutura } \\
\text { organizacional; Funções do enfermeiro } \\
\text { pediátrico; SAE-Pediatria) (C) } \\
\text { - Saúde da Criança e Adolescente (família e } \\
\text { instituições) (Crescimento e desenvolvimento; } \\
\text { Exame Físico Pediátrico; Hábito; Imunização; } \\
\text { Trauma / Violência) (C+P) } \\
\text { - Assistência Integral (Enfermidades pediátricas; } \\
\text { Urgências e UTI) (C+P + A) } \\
\text { - Estágio Clínico Pediátrico (Assistência de } \\
\text { enfermagem) (C+P+A) }\end{array}$ \\
\hline $\begin{array}{l}\text { - ENFERMAGEM } \\
\text { GINECOLÓGICA, } \\
\text { OBSTÉTRICA E } \\
\text { NEONATAL }\end{array}$ & $\begin{array}{l}\text { - Cognitivas: } \\
\text { - Adquirir conhecimentos, } \\
\text { habilidades e atitudes para } \\
\text { assistir as necessidades da } \\
\text { mulher durante todas as fases } \\
\text { vitais e durante o ciclo gravídico } \\
\text { puerperal normal (Cog + Mot + } \\
\text { Rel) } \\
\text { - Adquirir conhecimentos, } \\
\text { habilidades e atitudes, para } \\
\text { assistir ao recém-nascido normal } \\
\text { e de termo (Cog + Mot + Rel) }\end{array}$ & $\begin{array}{l}\text { - Abordagem Ginecológica (Evolução biológica; } \\
\text { Hormônios; Saúde da mulher; Violência; Doenças } \\
\text { da mama; Exames: procedimento de coleta de } \\
\text { Papanicolaou e exame da mama; Enfermidades) } \\
\text { (C + P + A) } \\
\text { - Abordagem Obstétrica (Pré-natal: diagnóstico; } \\
\text { exame físico; Gestação; Puerpério normal e } \\
\text { patológico; Enfermidades) (C + P + A) } \\
\text { - Abordagem Neonatológica (Fisiologia do recém- } \\
\text { nascido; Avaliação e assistência; Aleitamento } \\
\text { materno; Enfermidades do RN) (C + P + A) }\end{array}$ \\
\hline LEGENDA & $\begin{array}{l}\text { (Cog) cognitivas } \\
\text { (Mot) Motoras } \\
\text { (Ins) de inserção e atuação profissional } \\
\text { (Eq/Aut) equilíbrio e autonomia } \\
\quad \text { (afetivas) } \\
\text { (Rel) de relação interpessoal }\end{array}$ & $\begin{array}{l}\text { (F) Factuais } \\
\text { (P) Procedimentais } \\
\text { (C) Conceituais } \\
\text { (A) Atitudinais } \\
\text { (-) significa que não contém todas as etapas } \\
\quad \text { propostas na aceitação }\end{array}$ \\
\hline
\end{tabular}


Quadro 5 - Componentes dos planos de ensino das disciplinas assistenciais: Enfermagem Psiquiátrica, Enfermagem Preventiva e Comunitária. São Paulo, 2004

\begin{tabular}{|c|c|c|}
\hline Disciplinas & $\begin{array}{c}\text { Objetivos } \\
\text { (relacionados às capacidades que se } \\
\text { pretende desenvolver) }\end{array}$ & $\begin{array}{c}\text { Conteúdos } \\
\text { (segundo sua tipologia) }\end{array}$ \\
\hline $\begin{array}{r}8 \text { - ENFERMAGEM } \\
\text { PSIQUIÁTRICA }\end{array}$ & $\begin{array}{l}\text { - Aquisição dos conhecimentos sobre } \\
\text { os principais quadros psiquiátricos e } \\
\text { modalidades de tratamento, } \\
\text { elaboração de um projeto terapêutico } \\
\text { dentro do novo modelo de assistência } \\
\text { em saúde mental (Cog + Ins + Eq/Aut } \\
\text { + Rel) }\end{array}$ & $\begin{array}{l}\text { - Dados históricos da psiquiatria (F) } \\
\text { - Políticas de Saúde Mental }(F+C) \\
\text { - Assistência e Condições patológicas }(C) \\
\text { - Atendimento (Emergências terapias sociais; à } \\
\text { família; com a equipe interdisciplinar)(C+P) } \\
\text { - Aspectos ético legais }(A)\end{array}$ \\
\hline $\begin{array}{r}\text { - ENFERMAGEM } \\
\text { PREVENTIVA E } \\
\text { COMUNITÁRIA }\end{array}$ & $\begin{array}{l}\text { - Conceituar saúde pública (Cog) } \\
\text { - Identificar e descrever as funções de } \\
\text { cada elemento da equipe de saúde na } \\
\text { comunidade (Cog) } \\
\text { - Descrever a metodologia utilizada } \\
\text { para o diagnóstico e planejamento de } \\
\text { saúde para uma comunidade (Cog) } \\
\text { - Descrever finalidades dos programas } \\
\text { (Cog) } \\
\text { - Descrever e identificar as funções e } \\
\text { ações de enfermagem nos } \\
\text { atendimentos ao adulto, crianças e } \\
\text { mulher (Cog) } \\
\text { - Executar o trabalho multiprofissional } \\
\text { e multidisciplinar(Ins + Rel) } \\
\text { - Planejar, executar e avaliar a } \\
\text { assistência de enfermagem a } \\
\text { indivíduos, famílias e grupos da } \\
\text { comunidade (Cog + Ins + Rel) }\end{array}$ & $\begin{array}{l}\text { - Dados históricos da Saúde Pública (F) } \\
\text { - Políticas e Programas de Saúde (Família; } \\
\text { - } \text { Adulto, mulher, criança, trabalhador, idoso) (C) } \\
\text { - } \text { Camunizações (Programas; Rede de frio) }(\mathrm{C}+\mathrm{P}) \\
\text { - Legislação em Saúde }(\mathrm{C}) \\
\text { - Estágio Supervisionado }(\mathrm{C}+\mathrm{P}+\mathrm{A})\end{array}$ \\
\hline LEGENDA & $\begin{array}{l}\text { (Cog) cognitivas } \\
\text { (Mot) Motoras } \\
\text { (Ins) de inserção e atuação profissional } \\
\text { (Eq/Aut) equilíbrio e autonomia } \\
\quad \text { (afetivas) } \\
\text { (Rel) de relação interpessoal }\end{array}$ & $\begin{array}{l}\text { (F) Factuais } \\
\text { (P) Procedimentais } \\
\text { (C) Conceituais } \\
\text { (A) Atitudinais } \\
\text { (-) significa que não contém todas as etapas } \\
\text { propostas na aceitação }\end{array}$ \\
\hline
\end{tabular}

Como dados complementares cabe considerar a predominância da técnica expositiva como estratégia relevante para a apresentação dos conteúdos voltados ao desenvolvimento das capacidades privilegiadas.

Nesse sentido, o desenvolvimento da capacidade motora se daria em espaços e tempos diferenciados (tempo teórico $\mathrm{x}$ tempo prático), tendo como estratégia privilegiada a repetição de regras, técnicas e métodos (em laboratório ou ao vivo, no campo), apresentados e dispostos num ordenamento que se iniciaria por ações simples e limitadas (sinais vitais, curativos, banho, dentre outras técnicas em si), evoluindo para outras mais complexas e diversificadas. Habilidades relativas à 
dimensão de equilíbrio-autonomia, de relação interpessoal e de inserção e atuação integrada ao contexto profissional ${ }^{(19)}$ representariam experiências menos presentes, considerando as estratégias privilegiadas (aulas teóricas, teórico-práticas, estudo dirigido, seminários, trabalho de pesquisa, visitas técnicas, problematizações pouco explicitadas, dentre outras intervenções compatíveis com o modelo tradicional expositivo).

Outro elemento comum da avaliação das diferentes disciplinas diz respeito ao predomínio da avaliação por julgamento docente, pautado em nota teórica, prática ou teórico-prática, aparentemente voltados à mensuração do que o aluno sabe e faz.

Tendo por foco os objetivos elencados, é possível considerar que sua proposição visa, primordialmente, o desenvolvimento de habilidades motoras, sustentada por investimentos cognitivos no sentido de apresentar fatos e conceitos necessários à prática e que evoluiriam dos comuns aos específicos, sem necessariamente chegar a compor esquemas conceituais ampliados e integrados.

A organização dos conteúdos expressariam uma forte vinculação ao código fisiopatológico e a teoria das necessidades humanas básicas como norteadores dos cuidados, com poucos investimentos em temas sociológicos que dariam sustentação para a expressão de políticas e programas assistenciais e à abordagem psicossocial para a proposição de temas relacionais.

Processualmente, essa formulação compreenderia:

- Investimentos teóricos relativos à apresentação das bases conceituais da Enfermagem, aparentemente dissociadas de teorias do conhecimento, de referenciais filosóficos dentre outros conteúdos 
necessários à apreensão de significados dos fenômenos inerentes à prática do cuidar;

- Apresentação de técnicas, instrumentos e métodos relacionados em maior ou menor grau ao referencial teórico enunciado;

- A análise do processo de hospitalização que explicitaria as especificidades de uma prática instituída e instituinte, de caráter total descrito por Goffman ${ }^{(54)}$ pela ruptura das barreiras que separam as esferas da vida como dormir, brincar e trabalhar. Todos os aspectos da vida são realizados no mesmo local e sob uma única autoridade, as atividades são realizadas em companhia de um grupo de pessoas, todas tratadas da mesma forma, estabelecidos os horários ${ }^{(54)}$.

Essa abordagem aparentemente estaria limitada a exposições relativas ao doente e à equipe;

- O investimento em conteúdos procedimentais que gradativamente evoluiriam da destreza ou habilidade para o desempenho isolado (sinais vitais, curativos, banho), agregando regras, técnicas e métodos de proteção (biossegurança); ações mais complexas, diversificadas e sistematizadas (cuidado integral) até o cuidado específico, considerando novos ambientes (CC), novos sujeitos (criança e adolescente, mulher) novas abordagens clínicas (Doenças Transmissíveis, Psiquiatria), novos níveis de atenção (Enfermagem Preventiva e Comunitária). Seria possível identificar a confluência de diferentes referenciais para a organização dos conteúdos; e 
- Um espaço diferenciado e abrangente para a repetição, em laboratório ou campo de prática.

Sintetizando, seria possível considerar que essas intenções e investimentos educacionais estariam promovendo mobilizações parciais das diferentes habilidades propostas na medida em que:

- Os conteúdos factuais (dados, códigos, regras) estariam sendo apresentados, com pouca integração às estruturas de conhecimento, além de privilegiar a repetição em detrimento de organizações significativas de associações; ${ }^{(19)}$

- Os conteúdos conceituais estariam sendo apresentados sem garantia de tempo e de estratégias voltadas a elaborações e construções pessoais desses constructos;

- Os conteúdos procedimentais estariam privilegiando a reiteração ao invés de garantir uma organização em aberto, propícia para novos projetos de ação. A reflexão sobre a própria atividade, a consciência da ação, assim como a aplicação em contextos diferenciados, menos controlados não estariam garantidos;

- Os conteúdos atitudinais estariam sendo menos explorados a não ser no sentido da conduta pertinente. Seus componentes cognitivos (conhecimentos e crenças), afetivos (sentimentos e preferências) e condutuais (ações e declarações de intenções) aparentemente não mereceram referência nos domínios das diferentes disciplinas clínicas; além de, 
- Outros investimentos aparentemente pouco referidos nos planos de ensino, incluindo: atividades que permitem determinar os conhecimentos prévios em relação aos novos conteúdos; uma proposição significativa e funcional; uma adequação ao nível de desenvolvimento de cada aluno; uma formulação que represente desafios alcançáveis para o aluno e que, ao mesmo tempo, provoque conflito cognitivo, viabilizando a atividade mental, a atitude favorável, o esforço reconhecido, a autonomia, enfim, o aprender a aprender. ${ }^{(19)}$

Nesse sentido, essas intenções educativas seriam pouco disponíveis para a consolidação da competência clínica na medida em que o seu desenvolvimento pressupõe; ${ }^{(15)}$

- "Construir tanto o problema como sua solução, refletir, observar os dados em todos os sentidos, dar-Ihes consistência, esboçar hipóteses e analisá-las detalhadamente por meio do pensamento...";

- "Um trabalho de construção de conceitos e de novos saberes teóricos (ao menos para o estudante) a partir de situações singulares"; $e$

- "Um trabalho de integração e de mobilização de recursos adquiridos, criador de novas competências;

- "Colocar em prática as aquisições teóricas e metodológicas. Passa-se a trabalhar a mobilização, a orquestração, a sinergia e a contextualização de saberes já construídos, mas que o estudante ainda não pode utilizar diante de situações complexas";

- "Uma reflexão sobre o sistema de ação, tanto em seu componente consciente e racional (saberes declarativos, procedimentais, 
raciocínios explícitos) como em suas dimensões menos reflexivas, provenientes dos habitus e do insconciente prático"; enfim,

- "Ensinos ministrados de tal maneira que interrogação e a dúvida estejam constantemente inseridos na relação com o saber e que o professor não perca nenhuma oportunidade de reorientar uma postura reflexiva".(15)

Trata-se aparentemente, de uma abordagem que estaria dificultando o desenvolvimento da competência clínica, na medida em que potencializaria uma aprendizagem aquém do necessário à sua consolidação.

Tendo essa premissa como referência é possível identificar, nessa fragilidade da formação, um elemento a contribuir para a inespecificidade da prática assistencial do enfermeiro, reconhecida em inúmeras pesquisas.

Para De Domenico ${ }^{(6)}$, com a formação mantendo seu investimento da generalidade de conteúdos e práticas pulverizadas, sem a promoção do aprofundamento teórico e, conseqüentemente restringindo a construção de sistemas de conceitos que dariam sustentação a elaboração e implementação de projetos profissionais personalizados; estimularia a perpetuação da generalidade insconsistente, cujas repercussões prenunciam o despreparo e a inserção frágil nos mundos da formação e do trabalho.

Esta referência é corroborada também em estudos ${ }^{(8,11,55)}$ que destacam esses mecanismos vivenciados pela formação, propondo um ensino preconizado por ações no ideal, marcado pelo descompasso entre o proposto e o que será vivenciado na prática assistencial, sem explicitar durante a graduação a força que tem o contexto. Isto fica demonstrado também pelo significado apresentado pelo 
discente, do que seja aprender a ser enfermeiro, desconsiderando as condições determinantes, trazendo a tona o modelo vigente descontextualizado.

A marca do inespecífico, quando vivenciada no dia a dia, acentuada pela ausência de atividades originadas da própria capacidade analítica e pelo excesso de atividades impostas, tem contribuído para compor o perfil de um profissional impotente, angustiado, culpado e temeroso, que se depara com o sofrimento nesta vivência prática, mas tem a expectativa de satisfação futura, na transformação da organização e das condições de trabalho( ${ }^{(56)}$.

Assim, a ênfase na capacidade técnica, domínio comum aos profissionais com diferentes níveis de formação, estaria gerando profissionais pouco aptos "para a tomada de decisão mediante um julgamento que, tendo a ação clínica como referência, nem sempre consegue conjecturá-la sob diferentes aspectos e necessidades (técnica, político, social, econômico) para intervir prontamente”."(6)

Essa intenções educativas inscrevem-se na "ordem da fragmentação do eixo de formação, no ensino centrado no modelo médico, na dicotomização teóricoprática..., conformando um projeto técnico desconsiderando o mercado de trabalho, não se permitindo flexibilização, sendo o mesmo para todas as instituições destituídas de identidade".(57)

$\mathrm{Na}$ vigência dessa cultura, evidencia-se o descompasso entre uma competência clínica requerida como identidade profissional do enfermeiro no sentido de atender a uma dinâmica assistencial em transformação e uma capacitação técnica reduzida na medida em que a autonomia, a construção de projetos e a responsabilidade pela própria formação enquanto elementos potencializadores de competências continuam sendo pouco mobilizados entre graduandos de Enfermagem. 
Os resultados obtidos possibilitam, ainda, reiterar uma série de questões que também se adequam ao presente estudo no sentido de oferecer pistas para reconsiderar o planejamento disciplinar, cabendo perguntar se nesse empreendimento existem atividades: ${ }^{(19)}$

- Que permitam determinar os conhecimentos prévios que cada aluno tem em relação aos novos conteúdos de aprendizagem?

- Cujos conteúdos são propostos de forma que sejam significativos e funcionais para eles?

- Que são adequados ao nível de desenvolvimento de cada aluno?

- Que representem um desafio alcançável, quer dizer, que levam em conta suas competências atuais e as façam avançar com a ajuda necessária, portanto, que permitam criar zonas de desenvolvimento proximal e intervir?

- Que provoquem um conflito cognitivo e promovam a atividade mental necessária para que estabeleça relações entre os novos conteúdos e os conteúdos prévios?

- Que sejam motivadores em relação à aprendizagem dos novos conteúdos?

- Que estimulem a auto-estima e o autoconceito em relação às aprendizagens que se propõem?

- Que ajudem o aluno a adquirir habilidades relacionadas com o aprender a aprender, que Ihe permitam ser cada vez mais autônomo em suas aprendizagens?

Estas questões ainda que não formuladas já evidenciam que dificilmente esse projeto poderá atender aos princípios de uma aprendizagem significativa e 
compreensiva, a não ser na abordagem de conteúdos factuais e conceituais pouco complexos, passíveis de abordagens expositivas, com memorização posterior.

Ainda que não tenhamos a percepção docente acerca dessas questões, contamos com a participação discente enquanto graduandos que, tendo vivenciado quase toda a graduação tornaram-se elemento e produto desse processo, registrando representações de aprendizagem passíveis de complementar a análise pretendida.

\subsection{Representação da Aprendizagem entre Graduandos}

A análise documental associada à compreensão dos conteúdos ideativos formulados pelos graduandos forneceram elementos relevantes para a pesquisa, apreendendo expressões e investimentos discentes além de indicativos da concepção dos planejamentos de ensino, na interface com representações da experiência da aprendizagem clínica em suas múltiplas abordagens.

O aprofundamento compreensivo, tendo por baliza referenciais pedagógicos possibilitou a proposição de perspectivas para a construção de novas expressões da formação no âmbito superior da Enfermagem, visando o alcance dos objetivos propostos.

Os resultados obtidos serão gradativamente apresentados no sentido de caracterizar:

- Unidades de análise relativas ao planejamento das diferentes disciplinas que têm a formação clínica como responsabilidade e que poderiam evidenciar sua perspectiva processual de investimentos 
necessários, ainda que não suficientes para o desenvolvimento dessa competência (essa caracterização das disciplinas foi reportada no capítulo anterior);

- Aspectos identitários dos estudantes, incluindo: trajetória e investimentos de formação; projetos profissionais; hábitos de lazer e atributos decorrentes de uma auto percepção. A síntese dessas informações forneceria elementos significativos para a identificação do preparo formal dos discentes, o sentido dos investimentos complementares, a expressão de interesses e opções de entretenimento, além de representações que prenunciam indícios de ser relevantes para a identificação da bagagem pessoal mobilizada pelo graduando. Seriam as matrizes predisponentes de um ensino aprendizagem significativo, aberto às especificidades e diversificações dos percursos de formação e dos projetos de ação, após o término da graduação;

- Esquemas representacionais da dinâmica de aprendizagem clínica, incluindo: o próprio conceito; relatos de experiências no campo de prática, com ênfase nos incidentes críticos; além das apreciações acerca da percepção do desempenho clínico por parte de enfermeiros assistenciais. Assim, esses conteúdos agregariam esquemas de pensamento, de ação e de apreciações passíveis de caracterizar a estrutura formal e operacional da competência clínica desenvolvida na graduação. 
Esses foram os núcleos temáticos privilegiados na pesquisa, tendo por base resultados já apresentados, referentes ao planejamento das diferentes disciplinas e na seqüência os aspectos identitários dos estudantes e os esquemas representacionais da dinâmica de aprendizagem clínica. 


\subsubsection{Caracterização do grupo discente}

A composição dessa unidade analítica privilegia o perfil e o contexto individual e social dos estudantes categorizados segundo: a) faixa etária; sexo; trajetória escolar pregressa; b) tempo de conclusão do curso e investimentos correlatos à formação; c) hábitos de lazer; d) auto descrição; e) projetos profissionais relacionados ao término da graduação.

Preliminarmente cabe apresentá-los a partir de indicadores biológicos e percurso de formação.

Quadro 6 - Caracterização do perfil e trajetória escolar pregressa. São Paulo, 2004

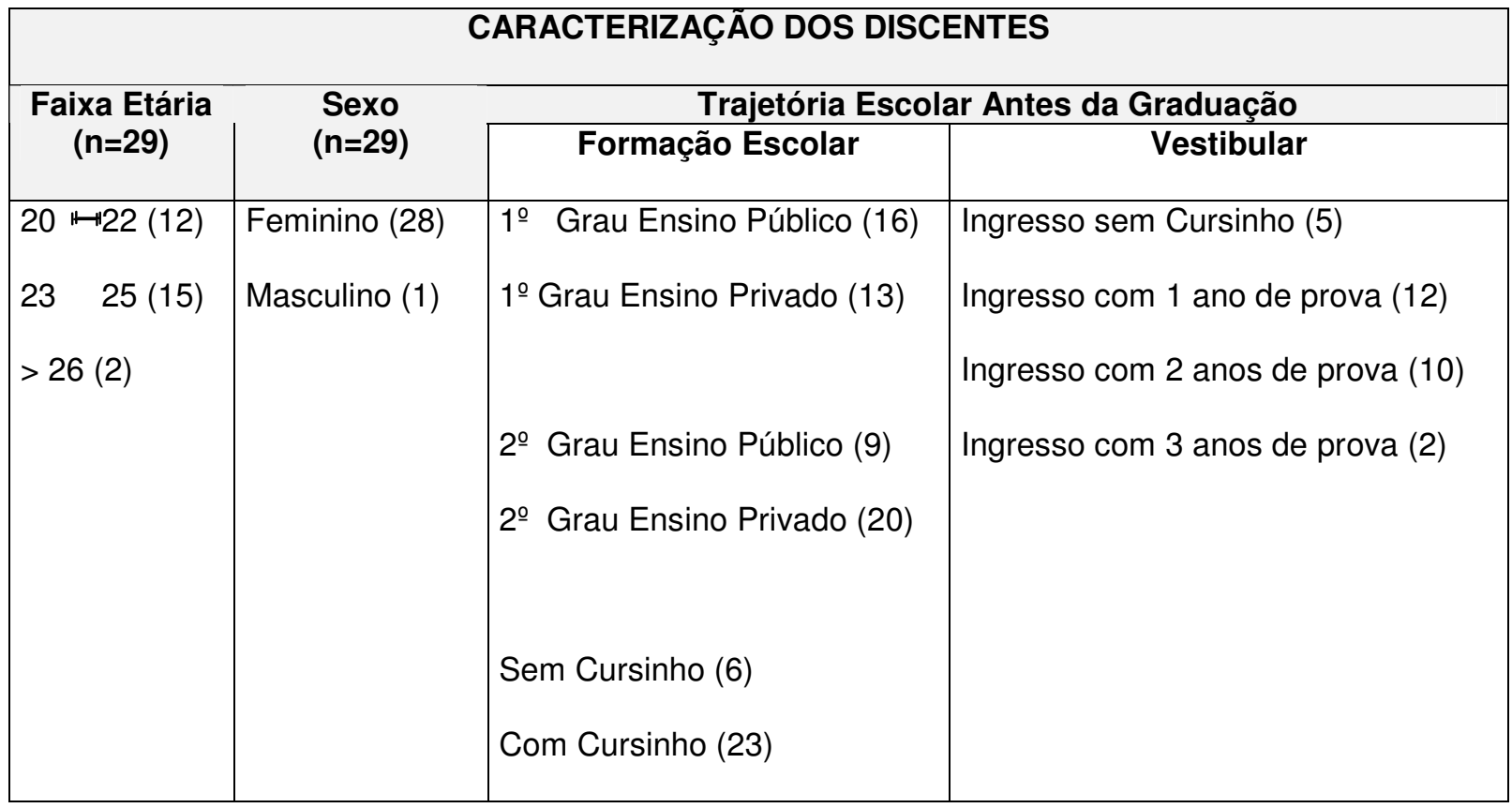

Este grupo foi composto por 29 alunos, finalizando o quarto ano da graduação em Enfermagem, sendo 28 alunos do sexo feminino e 1 aluno do sexo masculino. 
Este resultado já era esperado, pois faz parte do contexto profissional tal predominância. Em estudo regional referente a Força de Trabalho em Enfermagem no Estado de São Paulo, os autores verificaram que, de 1983 para 1996 houve um aumento de 6,6\% de profissionais na área de Enfermagem do sexo masculino, mas ainda assim predomina o sexo feminino, com $89,2 \%$. Estes dados permanecem com diferenças não significativas, corresponde a cada região e instituição de ingresso dos alunos. ${ }^{(58)}$

A faixa etária predominante é de 23 a 25 anos, no último ano da graduação. A maioria tem como primeira experiência a graduação em Enfermagem.

Nota-se que a faixa etária do estudo pode ser comparado com trabalho realizado por Matheus ${ }^{(8)}$ que teve, num dos grupos amostrais de sua tese, enfermeiras recém-formadas entre 23 e 27 anos de idade; evidenciando em ambos os estudos, uma idade de finalização acima do estimado, resultado compatível, tanto com a retenção nos vestibulares, referido por parte do grupo, como pela repetição no próprio curso.

O grupo vem de uma trajetória escolar de ensino fundamental e médio misto, onde a maioria fez o primeiro grau, 16 alunos, em escolas públicas e o inverso ocorreu no segundo grau quando 20 alunos estudaram em escolas particulares.

Esses dados reiteram uma tendência de investir no ensino médio transferindo-se das escolas públicas para as escolas particulares; é visível a intencionalidade em preparar-se para concorrer às vagas desejadas no ensino público superior, buscando reforços de formação média prenunciados no sistema particular de ensino. 
Destes 29 alunos, quase a totalidade, 23 referiram ter feito Cursinho e apenas 6 alunos prestaram o vestibular sem esse recurso, sinalizando uma dependência dessa complementação, apesar dos investimentos anteriores.

Quanto ao ingresso na faculdade, 5 estudantes passaram no vestibular sem cursinho, 12 alunos conseguiram passar na prova do vestibular após 1 ano de tentativa. Os demais precisaram prestar o vestibular por 2 anos ou mais, compondo uma maioria dependente de uma transição para o ensino superior mediado pelos cursos preparatórios.

Estes dados também refletem o contexto institucional da escola e curso escolhido pelo grupo. Uma escola pública, com vestibular coordenado pela Fundação para o Vestibular da Universidade Estadual Paulista-UNESP, que segundo Relatórios dos Vestibulares, ano de ingresso de $1998^{(59)}$ e $1999^{(60)}$ revelaram uma relação candidato vaga de $28,2 \%$ e $24,5 \%$ respectivamente. Dos inscritos para o vestibular constou 31 alunos do sexo masculino e 532 alunas do sexo feminino em 1998. Já em 199947 alunos do sexo masculino e 688 alunas do sexo feminino. ${ }^{(59,60)}$

As médias das notas classificatórias no vestibular dos alunos que fizeram matrícula no Curso de Graduação no ano de 1998 foi 57,87 e no ano de $199976,7 \%$ dos alunos classificaram-se com 57,5; 20\% com média até 72,5 e 3,3\% até 87,5 de nota classificatória; ${ }^{(59,60)}$ configura-se um grupo discente com uma performance suficiente para a aprovação, valendo destaque por sua classificação superior, ainda que minoritária.

Ampliando a análise segundo o ingresso, dos alunos da graduação no Curso de Enfermagem dos anos de 1997 a 2002, contendo os anos de 1998 e 1999 que foram os de ingresso desse grupo discente estudado, percebe-se pelo Relatório 
de Avaliação da Coordenação da Graduação ${ }^{(61)}$ que na média geral os dados são semelhantes quanto: o ensino do segundo grau predominantemente realizado em instituições particulares (64,7\%); freqüência à cursinho preparatório de 1 ano ou mais $(74,7 \%)$, número de vezes que prestou o vestibular 1 ou 2 vezes $(57,4 \%)$; faixa etária 21 anos (75\%) e as médias de notas classificatórias mantiveram-se em 57,0\%, com porcentagens menores de alunos com médias elevadas. Portanto, nesta perspectiva o grupo de alunos estudado mantem um perfil semelhante às demais turmas, referida nesta avaliação realizada pela Coordenação da Graduação na escola.

Destacando-se o contexto institucional da Escola Superior que estes alunos estudaram salienta-se os resultados obtidos ao participar do Exame Nacional de Cursos - ENC do Ministério da Educação, quando neste ano a Escola obteve, por meio dos seus alunos, a maior média nacional dentre as demais escolas que participaram do "Provão 2002."(62)

Este grupo de 29 alunos com essa trajetória que combina ensino público e privado, que fez uso de cursos preparatórios, com uma performance, na média, suficiente para a aprovação privilegiou investimentos em atividades complementares para graduação em Enfermagem, tais como: pesquisas de iniciação científica; participação em eventos extracurriculares; monitoria em disciplinas; participação em projetos de extensão; realização de estágios extracurriculares; alunos bolsistas; membros de conselhos na instituição. Esta formação complementar é apresentada a seguir. 
Quadro 7 - Caracterização do desenvolvimento discente complementar a graduação. São Paulo, 2004

\begin{tabular}{|l|l|}
\hline \multicolumn{2}{|c|}{ Trajetória Escolar Durante a Graduação } \\
\hline Duração da Graduação & 4 anos (27) \\
& 5 anos (2) \\
\hline Pesquisas & $1 \vdash 3(18)$ \\
& $4 \vdash 7(4)$ \\
& em branco (7) \\
\hline Eventos Extracurriculares & $1 \vdash 5(2)$ \\
& $6 \vdash 10(3)$ \\
& $11 \vdash 15(1)$ \\
& $16 \vdash 20(1)$ \\
& $>20 \quad(19)$ \\
& Em branco (3) \\
\hline Monitoria & Sim (7) \\
& Não (22) \\
\hline Projetos de Extensão & Sim (17) \\
& Não (12) \\
\hline Estágios Extracurriculares & Sim (24) \\
\hline Bolsistas & Não (5) \\
\hline Membros em Conselhos & PAE (5) \\
& FAPESP (5) \\
& Não Receberam (19) \\
\hline Graduação (4) \\
& Congregação (1) \\
& Moradia Estudantil (1) \\
& Não Participaram (23) \\
\hline
\end{tabular}

Esses dados evidenciaram uma dupla característica desse grupo: ter um desenvolvimento no mínimo adequado uma vez que a maioria completou a graduação no tempo regulamentar; e reforçando essa possibilidade ter uma postura pró ativa, buscando atividades complementares de forma significativa, considerando tanto a quantidade dessa produção quanto a diversidade de participações. As exceções estariam relacionadas à baixa oferta, tanto no que se refere à monitoria (disponível em apenas 3 disciplinas) quanto na representação em colegiados, cuja 
restrição decorre da inserção do Departamento de Enfermagem na Faculdade de Medicina, o que lhe garante poucas vagas de representação, inclusive discente.

A mesma consideração pode ser aplicada a análise da limitada condição de bolsistas, enquanto inserção em atividades de iniciação financiadas por agências de pesquisa na dependência de projetos docentes contemplados por essa cobertura. Nesse sentido, tanto a contenção orçamentária vigente, restringindo o financiamento público, quanto ao fato do corpo docente ainda estar, na sua maioria, em consolidação da própria identidade como pesquisadores, atuariam como condições limitantes à participação discente, o que não inviabilizou outras atuações voluntárias.

Quando analisadas no conjunto essas atuações conferem um caráter preferencial presente em todos os âmbitos de iniciação, privilegiando prioritariamente temas/projetos/cursos centrados: na abordagem à família (PSF); na prática desenvolvida nos extremos do Sistema de Saúde: saúde pública e emergência; com ênfase menor em temáticas aparentemente vinculadas à questões específicas (Centro Cirúrgico; Obstetrícia, Saúde da Criança, dentre outros), conforme agrupamento referidos a seguir:

- Temas das pesquisas: abordagem à família (16); centro cirúrgico (7); Obstetrícia (5); Saúde Pública (5); Pediatria (4); dentre outros;

- Participação em eventos extracurriculares: Trauma/ATLS/Urgência e Emergência (6); Saúde Pública (5); Centro Cirúrgico (5); Programa de Saúde da Família (PSF) (4); dentre outros;

- Inserção em projetos de extensão: Programa de Saúde da Família (PSF)(7); Administração (6); Liga da AIDS (4); Liga do Câncer (4); dentre outros. 
- Estágios extracurriculares realizados nas áreas: Programa de Saúde da Família (PSF) (6); Saúde Pública (6); Pronto Socorro (5); Berçário / UTI Neonatológica (4); dentre outros.

Produzir ciência é função intrínseca às responsabilidades da Universidade, sendo também um elemento preconizado pela Lei de Diretrizes e Bases da Educação Nacional $(\mathrm{LDB})^{(49)}$ quando trata da Educação Superior, atribuindo a esse âmbito de formação a responsabilidade de "estimular a criação cultural e o desenvolvimento do espírito científico e do pensamento reflexivo, incentivar o trabalho de pesquisa e investigação científica, visando o desenvolvimento da ciência e da tecnologia e da criação e difusão da cultura, e, desse modo, desenvolver o entendimento do homem e do meio em que vive".(49)

Estimular a utilização/participação na produção de ciência durante a graduação passa a ser uma importante estratégia, que dentre outras, será imprescindível para sustentar a prática profissional pautada em ciência, como base para a superação do caráter reiterativo, algumas vezes de senso comum ainda presente no seu cotidiano.

Trata-se de pensar a pesquisa como espaço fundamental no desenvolvimento de uma nova expressão de competência, direcionando uma atuação sustentada em evidências, uma atitude questionadora e propositiva de novos investimentos qualificadores da formação e da prática. Essa seria uma das funções da Universidade, um dos elementos identitários dos cursos desenvolvidos nesses centros de referência. 
Pode-se considerar que esse grupo apresentou indicativos de consonância com essa perspectiva na medida em que foram muitas as incursões tendo a pesquisa como referência.

Essa busca ampliada de formação representaria, ainda, tentativas de personalizar a própria capacitação buscando experiências específicas para além da graduação, como que sinalizando a percepção de demandas de mercado que têm no PSF/saúde pública e no atendimento especializado (UTI, PS, Trauma) reservas de trabalho enquanto áreas privilegiadas, inclusive no desenvolvimento de estágios extracurriculares.

Confrontando os dados com o referencial teórico que norteia a construção de competência, vê-se que a realização de eventos e cursos extracurriculares, participação em projetos de extensão, realização de pesquisas, participação em monitorias e conselhos, dentre outros; seriam investimentos necessários, ainda que não suficientes para o desenvolvimento de discentes, dependendo de outros espaços de criação.

Segundo Le Boterf citado por Perrenoud ${ }^{(31)}$ "A competência não é um estado mas um processo. A competência não reside nos recursos (conhecimentos, capacidades...) a serem mobilizados, mas na própria mobilização desses recursos. Para haver competência, é preciso que esteja em jogo um repertório de recursos (conhecimentos, capacidades cognitivas, capacidades relacionais...)"

Este repertório de recursos tem se constituído por estas e outras ações, que serão apresentadas e mostram o movimento dos alunos no sentido de, ao final, estarem em condições de "jogar", continuar no "jogo". Existe a perspectiva de ação e continuidade, condições necessárias para as pessoas e profissionais manterem-se em movimento. 
Nota-se que embora o currículo não delimite espaços formais para estas realizações, bem como, ainda efetivamente não reconheça oficialmente a incorporação destas atividades na forma de créditos, estes alunos encontraram maneiras e tempos para tais investimentos.

Considerando a Lei de Diretrizes e Bases da Educação Nacional (LDB) e citação feita pelas Diretrizes Curriculares Nacionais do Curso de Graduação em Enfermagem ${ }^{(16)}$, as "atividades complementares deverão ser incrementadas durante todo o Curso de Graduação em Enfermagem e as Instituições de Ensino Superior deverão criar mecanismos de aproveitamento de conhecimentos, adquiridos pelo estudante, através de estudos e práticas independentes presenciais e/ou distância. Podem ser reconhecidos: Monitoria e Estágios; Programas de Iniciação Científica; Programas de Extensão; Estudos Complementares; Cursos realizados em outras áreas afins”.(16)

$\mathrm{Na}$ escola há esse entendimento, com o desejo de proporcionar tal flexibilidade e reconhecimento, porém, ainda efetivamente não se conseguiu. Vislumbra-se que a implementação do projeto político pedagógico que está em reconstrução poderá ter um olhar também para estas questões.

Havendo um consenso do grupo que dirige e atua no ensino da graduação, e, tendo uma apropriação real do que é competência em Enfermagem, construir um currículo que permita estes espaços será um exercício possível e necessário para valorizar e proporcionar aos alunos realizações reconhecidas e sem que precise haver "mecanismos de burla", como falta em aulas com ou sem consentimento docente para ir a congressos participar e apresentar trabalhos e realizar as outras atividades de extensão e de pesquisa. 
Compondo o montante de investimentos privilegiados pelo grupo, foram referidas outras participações significativas durante a graduação. Houve 20 citações registradas como relevantes, sendo 10 delas, a maioria, relativas à participação no Centro Acadêmico. As demais citações agregaram: aulas e palestras; trabalho voluntário em campanhas; apresentação de trabalhos em eventos internacionais; coordenação de projetos e campanhas, dentre outras iniciativas no auto desenvolvimento, ocupando espaços e cenários significativos para a atuação/veiculação do saber.

Percebe-se o movimento e o investimento feito por eles durante 0 processo de graduar-se possibilitando adquirir os recursos necessários para, num processo contínuo, constituir-se competente para as ações da profissão.

Entende-se que para ser competente, esses alunos terão que, além dos recursos, ter a capacidade de mobilizá-los para enfrentar as situações que lhes serão apresentadas ${ }^{(14)}$ configurando um interstício entre 0 auto investimento e 0 investimento da graduação no sentido de promover condições de validação dos projetos de ação formuladas.

De toda forma, estas expressões oriundas desse grupo personificado nos investimentos, possibilita essa percepção de alunos que buscam além do que é requerido e oferecido pela graduação. Parece que eles buscaram uma complementação de formação também pela noção de constituição de identidade e auto-realização e carreira futura.

Destaca-se também com uma realização importante, que deste grupo de alunos, uma em particular obteve reconhecimento pelo desempenho adquirido ao prestar o Exame Nacional de Cursos (ENC) - Provão 2002 - do Ministério da Educação, quando obteve o melhor desempenho nacional, recebendo como prêmio 
de primeira colocada uma bolsa para cursar o Mestrado, que será fomentada pela Coordenação de Aperfeiçoamento do Pessoal de Nível Superior (CAPES). Esta aluna no ano de 2003 está cursando residência em PSF-UNESP e ao término do curso prestará a pós-graduação stricto sensu.

Esse grupo parece ter aliado aos investimentos o aprimoramento e o cultivo de hábitos de vida que podem ser lidos como saudáveis. Nessa perspectiva emergiram 4 subcategorias: 1 - Lazer; 2 - Aprimoramento; 3 - Religiosidade e 4 - Relacionamento, conforme esquema a seguir. 


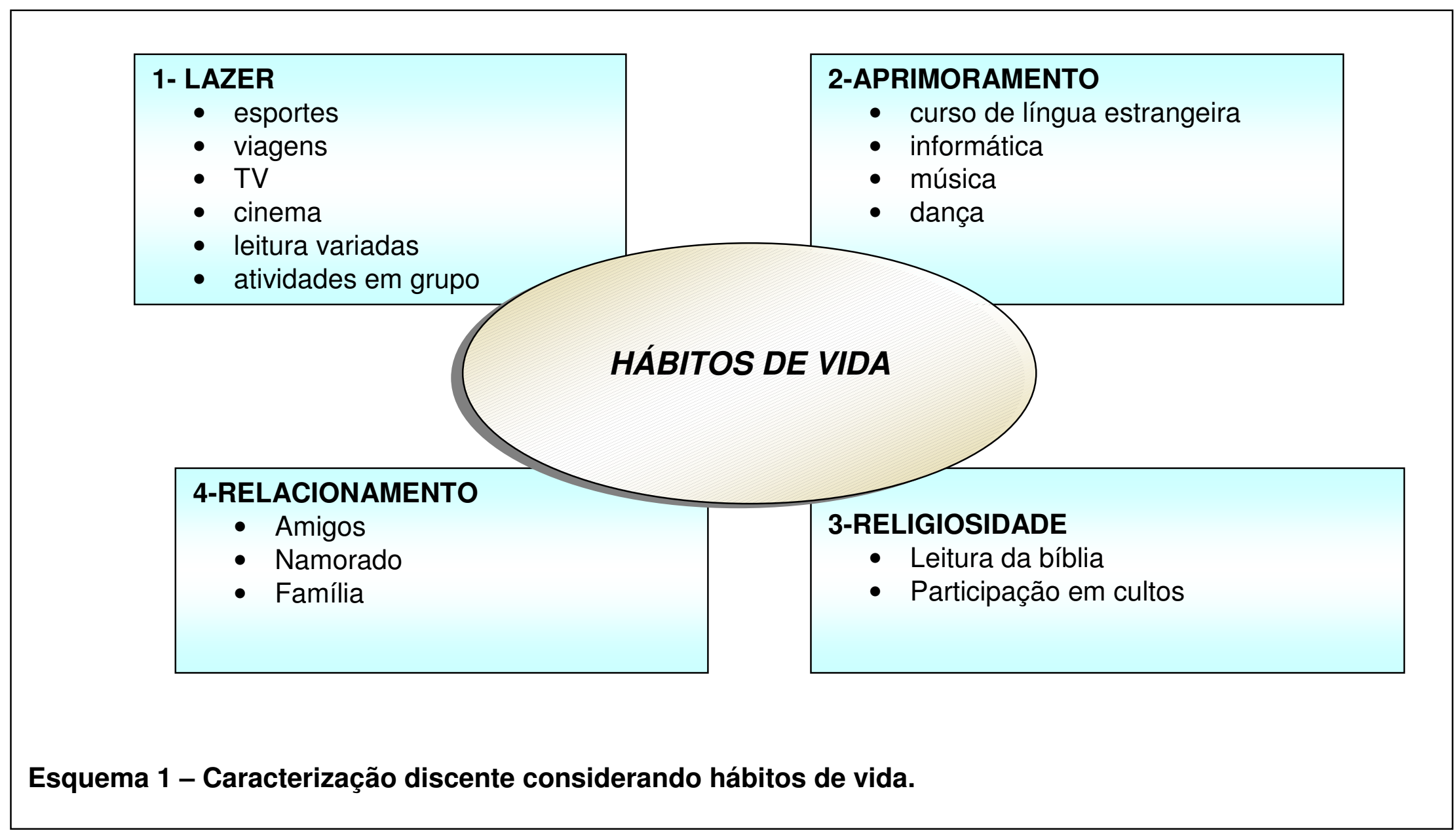


Esses dados evidenciam um grupo que apesar da carga horária intensa da Graduação investiu em atividades de cunho social e entretenimento buscando hábitos de vida saudáveis na perspectiva do lazer diversificado, ativo, cultural, relacional. Investir em lazer pode ir além da idéia de descansar, ele pode ampliar os horizontes, pode aumentar sua "bagagem", promovendo troca, descoberta, compartilhamentos. Quando se realiza cursos, viagens, leituras, pode-se aprimorar habilidades, descobrir talentos, complementar a formação, viver melhor. ${ }^{(63)}$

E este grupo demonstrou sintonia com essa perspectiva, referindo investimentos em cultivar atividades diversificadas. As expressões são múltiplas e conferem a possibilidade de ter boa qualidade de vida numa cidade do interior do Estado de São Paulo.

Esses estudantes também referiram investimentos no auto aprimoramento, pressupondo uma sintonia em desenvolver requisitos de empregabilidade (outra(s) língua, informática). Foram também relatadas iniciativas voltadas à música e à dança como atividades privilegiadas para a realização pessoal/inserção social.

Acessar esses dispositivos, amplia o domínio lingüístico, passa a ser um requisito de pertinência num mundo globalizado e informatizado, compondo investimentos relevantes para o aprimoramento pessoal que foram valorizados pela maioria do grupo, nos relacionamentos profissionais e na expansão deles.

Esses estudantes também manifestaram um desejo de pertença, uma valorização da dimensão relacional, quer na perspectiva dos vínculos afetivos (parentes, amigos, parceiros) quer na participação religiosa (participação em eventos). 
Como síntese, é possível considerar que esse grupo discente buscou formação ampliada sem esvaziar espaços de vida e exercícios de prazer, de relação, de transcendência, conforme atestam os depoimentos a seguir.

\section{1 - LAZER}

\section{Esportes}

“...fazendo esportes...nadando...caminhando uma hora todos os dias... indo para a academia... fazendo ginástica... musculação... fazendo trilhas, cachoeiras, cuesta... fazendo alpinismo e rapel... adoro esportes..... (1, 4, 5, 9,10, 11, 14, 15, 16, 18, 20, 21 , $22,23,26,27,28,29)$

\section{Viajens}

"Viajando a lazer quase todos os meses... para casa de alguns colegas... cidades vizinhas... para Bauru... a passeio... conhecendo Botucatu indo às cachoeiras, cuesta... indo a São Paulo para fazer compras... viajando...”. (1, 4, 5, 9, 10, 13, 14, 18, 24, 25)

TV

"Assistindo TV, principalmente o jornal... novelas... filmes... assistindo TV como único lazer..". (1, 2, 3, 5, 10, 13, 17, 19, 20, 25)

\section{Cinema}

"Indo ao cinema quase toda semana... gostando de cinema... assistindo muitos filmes no cinema... indo ao cinema..." (1, 4, 9, 10, 12, 15, 19, 20, 21, 23, 27, 28, 29) 


\section{Leituras variadas}

"Lendo livros de diferentes abordagens... livros de literatura... poesia de Fernando Pessoa... revistas... jornais... literatura variada e quase tudo de Rubem Alves... assuntos diferentes como auto ajuda... lendo 1 livro por semana". (1, 4, 6, 8, 10, 12, 14, 17, 19, 21, $22,24,27,28,29)$

\section{Atividades em grupo}

"Reunindo amigos em casa para comer e cantar... churrasco para os amigos... cozinhando e convidando amigos para comer em casa... indo às festas da Faculdade... indo para festas, pizzarias, bares... indo aos restaurantes, lanchonetes, barzinhos e cafés". $(1,3,5,12,13,17,19,20,21,23,26,29)$

\section{2 - APRIMORAMENTO}

"Fazendo inglês.. espanhol duas vezes por semana... aprimoramento auto didático em francês, espanhol, japonês e mandarim... curso de música... informática, produção de alimentos, jardinagens, artesanato... informática... curso de dança de salão há 6 anos..." $(1,3,4,5,7,8,9,11,12,13,14,16,17,18,19,20,21,23,26,28,29)$

\section{3 - RELIGIOSIDADE}

"Ensaiando e cantando, fazendo peças teatrais de fantoches na igreja... indo à missa... indo ao culto... viajando para ir a eventos religiosos... lendo livros espíritas... lendo a Bíblia...”. (5, 10, 14, 24, 27) 


\section{4 - RELACIONAMENTO}

\section{Amigos}

"Fez amigos em vários cursos da Faculdade... gostando de sair com os amigos... reunindo-se com amigos... indo à casa de amigos...” (2, 3, 4, 5, 7, 8, 15, 17, 23, $24,25,27)$

\section{Namorado}

"Sempre junto com o namorado... namorando e fazendo todas as atividades com ele... paquerando muito... namorando bastante...”. (5, 7, 8, 13, 14, 18, 19, 20, 21, 25, 29)

\section{Família}

"Ficando com os pais e avós... oferecendo carinho e apoio à família... curtindo o irmão, priminha que é bebê... cuidando do avô com câncer... ficava bastante com a família". (5, $10,21,29)$

Complementando a composição desses dados foram analisadas representações relativas à AUTO-DESCRIÇÃO, de como se percebem enquanto seres humanos. Sabe-se que pessoas vivem e constroem representações acerca de si, do mundo, dos objetos e nesse sentido buscou-se junto a elas próprias as expressões que tinham de si. Essas auto-representações tiveram por finalidade acessar expressões identitárias enquanto matriz constitutiva do vir a ser profissional.

O conceito de representação designa aquilo que se representa, o que forma o conteúdo concreto de um ato de pensamento e em especial a reprodução de uma percepção anterior. ${ }^{(64)}$ 
Da análise dos relatos, tendo como foco a AUTO-DESCRIÇÃO, emergiram 5 subcategorias analíticas como atributos comuns da personalidade, relativas às: 1-Expressões de humor; 2-Estilo de relacionamento; 3-Ritmo de ação; 4 - Organização/Iniciativa e 5-Expressão afetiva, conforme o exposto a seguir. 


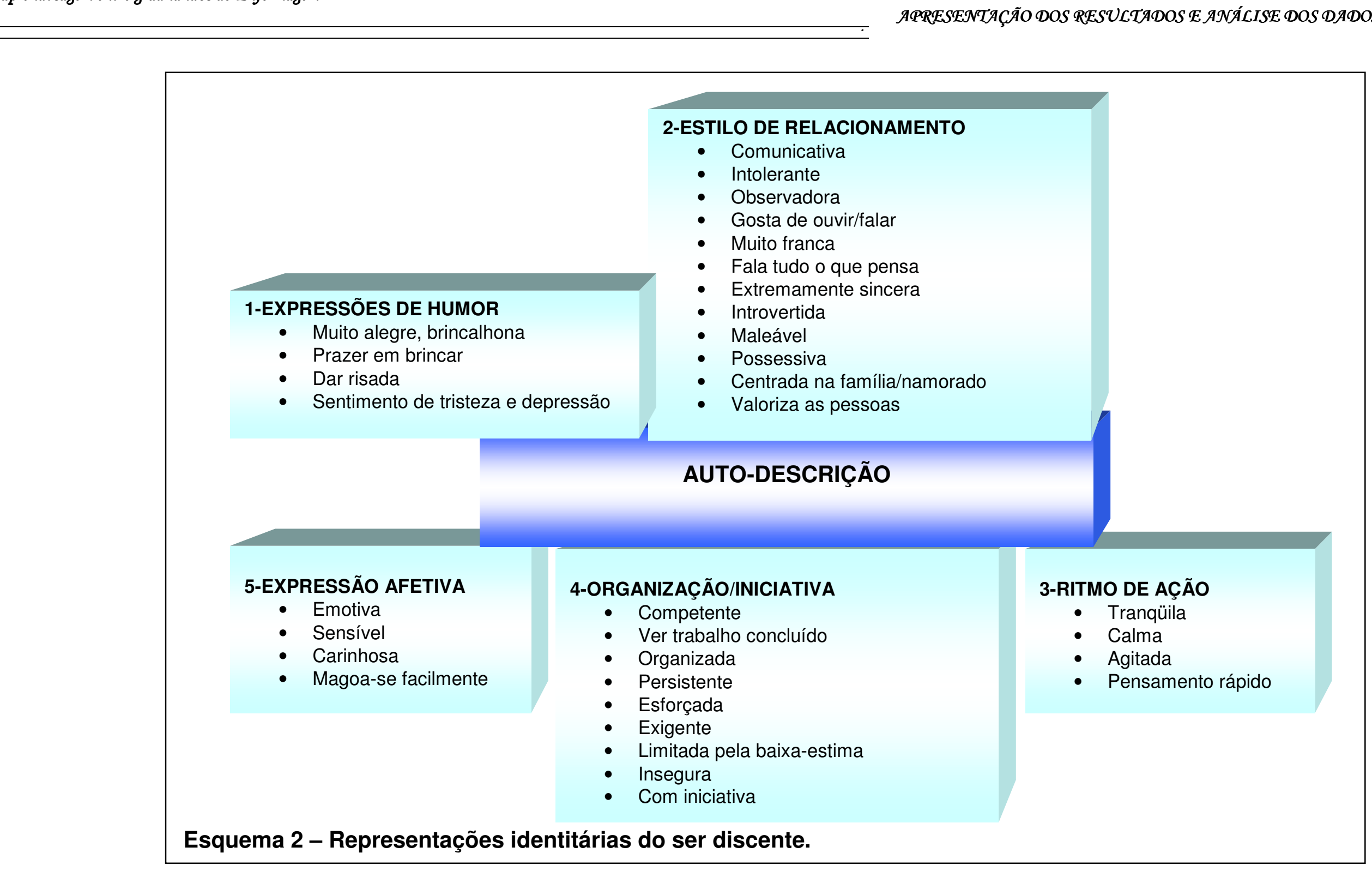

Magda Cristina Queiroz Dell Acqua 
Nessa representação é possível identificar, preliminarmente um gradiente de expressões possíveis para os estilos de ser referidos, com possibilidades de inclusão polarizadas em todos os agrupamentos (alegria/depressão; intolerante/maleável; insegura/com iniciativa; calma/agitada, dentre outras possibilidades de ser). Nesse sentido não haveria "um estilo" porém vários estilos de ser ou de representar-se.

É possível identificar ainda indicativos de repertórios cognitivos, afetivos e de ação passíveis de sustentar expressões de competências compatíveis com o exercício de uma profissão de nível superior. Por outro lado, evidencia-se uma representação marcada também por sofrimento psíquico, reforçando a polaridade de humor, de estilo de relacionamento e de ação já referido.

Esse componente identitário mereceria investimentos docente, no sentido da identificação e da adequação de estratégias de ensino compatíveis com os estilos e ritmos representados, incluindo o aconselhamento terapêutico nos casos adequados.

$\mathrm{Na}$ escola há um espaço terapêutico formal, onde os alunos que necessitam são encaminhados e acompanhados por psicólogas designadas especificamente para estes atendimentos. Isto é feito pela solicitação do aluno ou de docentes, que detectando estas demandas sugerem e até são mediadores para o encaminhando.

A percepção docente passa, por vezes, pela demanda destas necessidades de apoio, e não se sabe sistematicamente se há também outras estratégias para possibilitar um processo de ensino/aprendizagem com olhar singularizado. 
Caberia considerar, também, a predominância de uma propensão para o ordenamento / controle parecendo evidenciar uma atitude voltada para os resultados da ação (exigência, ver trabalho concluído, organização). São menos referidos atributos de ação inerentes à proposição, à criação, a experimentação.

Dentre os atributos pessoais, merece destaque as Expressões de humor que revelam uma disposição de espírito, a capacidade de perceber, apreciar ou expressar o que é divertido. ${ }^{(65)}$ Pode-se evidenciar uma reserva de vitalidade a ser utilizada como sustentação para as tensões próprias da dinâmica de formação/trabalho. Restaria saber, em investimentos futuros, como essas expressões seriam mobilizadas pela graduação e pelos embates com a prática. Impossível não destacar a referência de tristeza e depressão que associada a outras autorepresentações (intolerância, introversão, baixa auto-estima, insegurança, possessividade, dentre outras) comporia expressões de personalidade a merecerem investimentos diferenciados no sentido da superação possível.

Essas representações também enfatizam a esfera dos relacionamentos. Cabe salientar que a competência relacional faz parte do elenco de elementos e recursos a serem intencionalmente mobilizados. Essa essencialidade esta ligada a competência fundamentalmente atrelada a uma prática social de certa complexidade, também a um conjunto de gestos, posturas e palavras contidas numa prática que Ihe confere sentido e continuidade ${ }^{(14)}$. Atributos pessoais como facilidade em comunicação, capacidade de ouvir/falar, sinceridade, maleabilidade, valorização do outro comporiam representações de ser em consonância com habilidades empáticas imprescindíveis ao desenvolvimento da competência relacional.

Deste atributo necessário a composição da competência e especificamente da competência relacional, destaca-se então a definição de empatia 
definida como "habilidade cognitivo-afetiva de integração, agregando a capacidade de discriminar chaves afetivas no outro, assumir a perspectiva do outro (sempre na condição de outro), respondendo afetivamente ao seu sofrimento, transmitindo entendimento de tal maneira que este se sinta verdadeiramente compreendido e acolhido. (...) A forma mais elaborada de empatizar promove: maior entendimento na interação, intensificação de afeto, alívio da angústia da outra pessoa (com possíveis mudanças na condução dos seus problemas), tornando o empatizador mais aceito e com auto-estima elevada".(66) Portanto, agir empaticamente significa também "estar disponível para ver as coisas de acordo com o ponto de referência da outra pessoa e demonstrar um interesse genuíno pelo bem-estar do outro".(66)

Expressões afetivas pautadas em sensibilidade seriam pressupostos interacionais imprescindíveis a uma profissão de ajuda, podendo funcionar como elemento e produto de prática assistencial competente nessa dimensão. Haveria, porém, o risco presente no excesso (magoar-se com facilidade), evidenciando mais um foco de atenção a merecer investimentos de acompanhamento.

O ritmo de ação referido pelo grupo valoriza, tanto uma atuação controlada, mediada pelo calmo e tranqüilamente quanto o esgotamento ou ausência desses recursos (agitação). Novamente evidencia-se a diferença e, por decorrência, a necessidade de adequar investimentos de ensino considerando tais expressões.

Quando confrontados os dados, que são as representações dos alunos sobre si, com o referencial teórico sobre competência, percebe-se uma visão ampliada, com múltiplas expressões referentes às dimensões do sentir, relacionar-se, agir, organizar, planejar, bem como ter iniciativa. Essa diversidade seria compatível e adequada, pois a competência passa pela capacidade do sujeito 
em mobilizar o todo ou parte de seus recursos cognitivos e afetivos para enfrentar uma família de situações complexas ${ }^{(31)}$.

Não estamos analisando neste momento, as mobilizações, porém os recursos, que trazem em si a possibilidade de futura articulação e então de mobilizações, com resultado esperado para ser competente.

Para os alunos que colocam nestas expressões a sua forma de ser, com elementos de proposição de interação e persistência para atingir as metas propostas para si e para profissão, fica a percepção de um potencial de realização. Os recursos são variados e passíveis de mobilização dependentes das situações inéditas a serem experimentadas no decorrer da graduação.

Assim, é possível considerar que esses alunos trariam um substrato constituído no decorrer da própria vida, reforçado por investimentos pessoais e de formação passíveis de sustentar o desenvolvimento de competências dependentes, porém, de situações de aprendizagem potencializadas.

As unidades de registro que compõem estas categorias são apresentadas a seguir:

\section{1 - EXPRESSÕES DE HUMOR}

"Sou uma pessoa muito alegre... bom humor, o riso enriquece... alegre, brincalhona... adoro dar risada... adoro sorrir, alegre...alegre...porém me encontro triste, um pouco deprimida..." $(1,5,9,10,13,14,15,18,21,23,24,28)$

\section{2 - ESTILO DE RELACIONAMENTO}

“...comunicativa... gosto de ouvir as pessoas e de falar, embora seja tímida... adoro conversar, conhecer novas coisas e pessoas... às vezes tanta franqueza e sinceridade acabam assustando as pessoas, entendem como rispidez... meu principal defeito é falar 
tudo o que penso... incomunicável com pessoas que não gosto e extremamente sincera com as que gosto... falo bastante, as vezes de mais... gosto de falar pouco, ...não me abro com qualquer pessoa, antes de falar eu penso... Sou maleável com as pessoas mas dura comigo mesmo... gosto de trabalhar com pessoas carentes, idosos, na saúde da mulher... adoro conhecer novas pessoas... adoro sair me divertir, minha família, adoro cuidar... bastante possessiva, gosto de tomar frente das situações, de mandar... gosto de estudar, de namorar e sair com amigos... amo minha família... tenho dificuldade em iniciar novos relacionamentos... ligada à família, mãe e namorado... amo muito a Deus em $1^{\text {o }}$ lugar também meus pais, meu noivo, meus irmãos e amigos... valorizo as pessoas, amigos, familiares..." (1, 2, 3, 4, 6, 8, 10, 12, 14, 15, 16, 19, 21, 23, 24, 25)

\section{3 - RITMO DE AÇÃO}

“...calma, tranqüila... uma pessoa agitada... séria, centrada... calma e prezo muito a sinceridade... calma mas não gosto de falar... extremamente agitada... sou aventureira, competitiva e adoro desafios... calma, dedicada... pensamento rápido, impaciente..." (3, $4,6,8,9,11,18,25,28)$

\section{4 - ORGANIZAÇÃO/INICIATIVA}

“...muitas vezes sou um pouco insegura em relação à tomada de decisões... finalizando, tenho uma baixa auto-estima... um pouco insegura mas determinada... tenho iniciativa... me acho frágil, fraca... me realizei na escolha da profissão... Procuro sempre me aprofundar e aprender temas novos, ser competente... ver meu trabalho, pois seja quais dificuldades quero poder concluí-lo... me motiva o trabalho e quando consigo atingir os objetivos... adoro cuidar das pessoas, sou competente... gosto de planejar, odeio quando não sai como o planejado... me realizei na escolha da profissão... gosto do trabalho e me motiva a persistência, não desistir até que eu consiga... esforçada, detalhista, exigente, persistente e adoro minha profissão... sou perseverante...". (1, 3, 6, 8, 10, 11, 14, 15, 19, $20,21,22,24,25,26,29)$ 


\section{5 - EXPRESSÃO AFETIVA}

“...sou emotiva mas poucas vezes transmito... muito sensível.... compreensivo e muito carinhoso... sou emotiva e carinhosa e gosto de receber carinho também... sou carinhosa mas me magôo fácil... carinhosa e adoro crianças..." (6, 8, 9, 10, 20, 26)

Como elemento complementar da caracterização pleiteada foi solicitado ao grupo que delineasse seus projetos ao término da graduação.

Essa representação constitutiva foi incluída no estudo por considerá-la como expressão privilegiada de competência. Nesse sentido, projeto significa para Barbier (29) "não é uma simples representação do futuro, do amanhã, do possível, de uma idéia, é o futuro a fazer, um amanhã a concretizar, um possível a transformar no real, uma idéia a transformar em acto".

De Domenico ${ }^{(67)}$ acrescenta que "os projetos são estruturados pelos valores que são, em parte, abstrações desejáveis pelos indivíduos, mas também produto de uma cultura e organização social. Assim, os projetos traduzem-se pelo encontro de aspirações individuais e também coletivas, uma vez que são permeados pelo arcabouço cultural e social no qual os indivíduos estão inseridos".

Por decorrência, a ausência de projetos pressupõe uma existência reiterativa, sem desejos para o alcance de aspirações, enfim, uma expressão esvaziada de sentido e de intencionalidade.

Cabe salientar que apesar de relevante, a formulação de projetos como mediadores da aprendizagem não parece ser uma realidade no âmbito da Enfermagem. Estudo anteriormente desenvolvido junto a formandos de Graduação em Enfermagem desvelou que apesar de alguns alunos terem demonstrado sintonia 
com as demandas de mercado constituindo seus projetos profissionais e outros transcenderem a percepção dos indícios de mercado projetando seus próprios desejos, entretanto, outros projetos apresentaram como baliza os ditames institucionais, pouco elaborado na expressão de desejos e estratégias que poderiam vislumbrar a possibilidade de (re) elaboração de atitudes e comportamentos em busca da realização dos ideais. ${ }^{(67)}$

Neste estudo, os projetos referenciam-se a eventos voltados para o auto aprimoramento como que buscando a complementação de experiências anunciadas na Graduação.

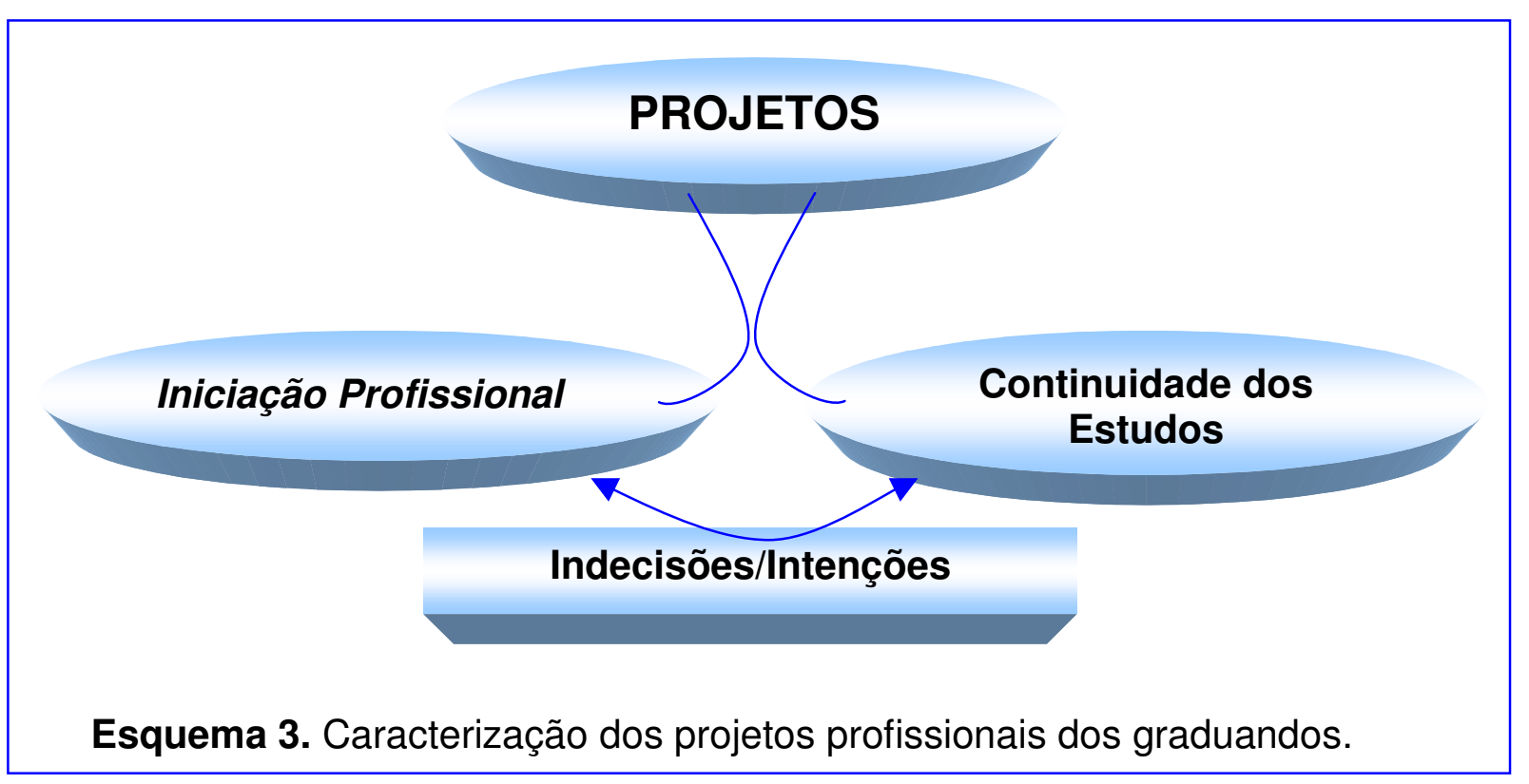

A análise dos depoimentos parace evidenciar muito mais opções, enquanto indicativos de iniciativas futuras, do que propriamente projetos.

Nesse sentido, os investimentos na formação/experiência, bem como as atividades práticas não estariam promovendo pontes entre esta formação e a inserção profissional. Também não estariam direcionando e dando sustentação às opções preferenciais por sua vez pouco consideradas pela graduação. 
É possível argumentar que ao término do curso esses alunos não teriam conseguido dar vida aos próprios projetos de ação. Estariam chegando ao mercado de trabalho fragilizados, querendo trabalho "no que for possível" / sem que o sentido dessa opção se manifestasse.

Os discursos a seguir ilustram as discussões.

“...em primeiro lugar pretendo trabalhar, prefiro a área intra hospitalar, UTI... trabalhar a princípio e depois me especializar, queria PSF... a princípio trabalhar na área de saúde pública, pois a autonomia conferida ao enfermeiro me agrada... vou morar em Brasília, pretendo ingressar no mercado de trabalho... pretendo trabalhar tanto por necessidade financeira como para adquirir experiência, áreas de Emergência, Pronto Socorro...” (8, $10,12,15,18,23,28)$

“...não decidi o que farei, trabalhar e tentar conciliar alguma especialização em UTI adulto... pergunta delicada, o que farei agora?... grande dúvida, ainda não encontrei algo que eu ame de paixão, tenho certeza do que eu não gosto... ainda estou perdida, vou prestar aprimoramento e residência em Nefrologia e se surgir um emprego também será bem vindo". (6, 19, 20, 21, 27)

"Minha área de preferência é Saúde Pública, Programa de Saúde da Família (PSF)... prestar aprimoramento em Saúde Pública na UNESP, também PSF e após prestarei mestrado e doutorado, gostaria de não parar de estudar... em março já estarei ingressando no meu tão sonhado mestrado na área de psiquiatria na USP-Ribeirão Preto... realizar uma especialização na área da saúde da mulher ou saúde da família, continuar estudando e fazer o mestrado e depois o doutorado..." (2, 4, 12, 17)

Como síntese dessa fase do estudo é possível considerar as referências práticas para identificação de peculiaridades desse grupo discente, potencializando 
a tomada de consciência docente acerca da complexidade do ser estudante, dos investimentos por eles privilegiados, dos vazios presentes ao término da graduação.

Os resultados apresentados evidenciaram retratos do que vêm ocorrendo com esses alunos, evidenciando desafios e dilemas presentes no desenvolvimento da competência clínica, com ênfase nas inter-relações entre o próprio conceito e as experiências vivenciadas na prática assistencial, compondo a próxima etapa do estudo, a ser apresentada a seguir.

\subsubsection{Conceitos de competência sob o prisma discente}

Tendo por referência o conceito de competência clínica privilegiado no estudo, buscou-se acessar construções de sentido próprias relativas ao tema. 0 resultado obtido superou as expectativas, na medida em que ampliou e tornou mais complexa a constituição do conceito, conforme evidencia o esquema a seguir. 


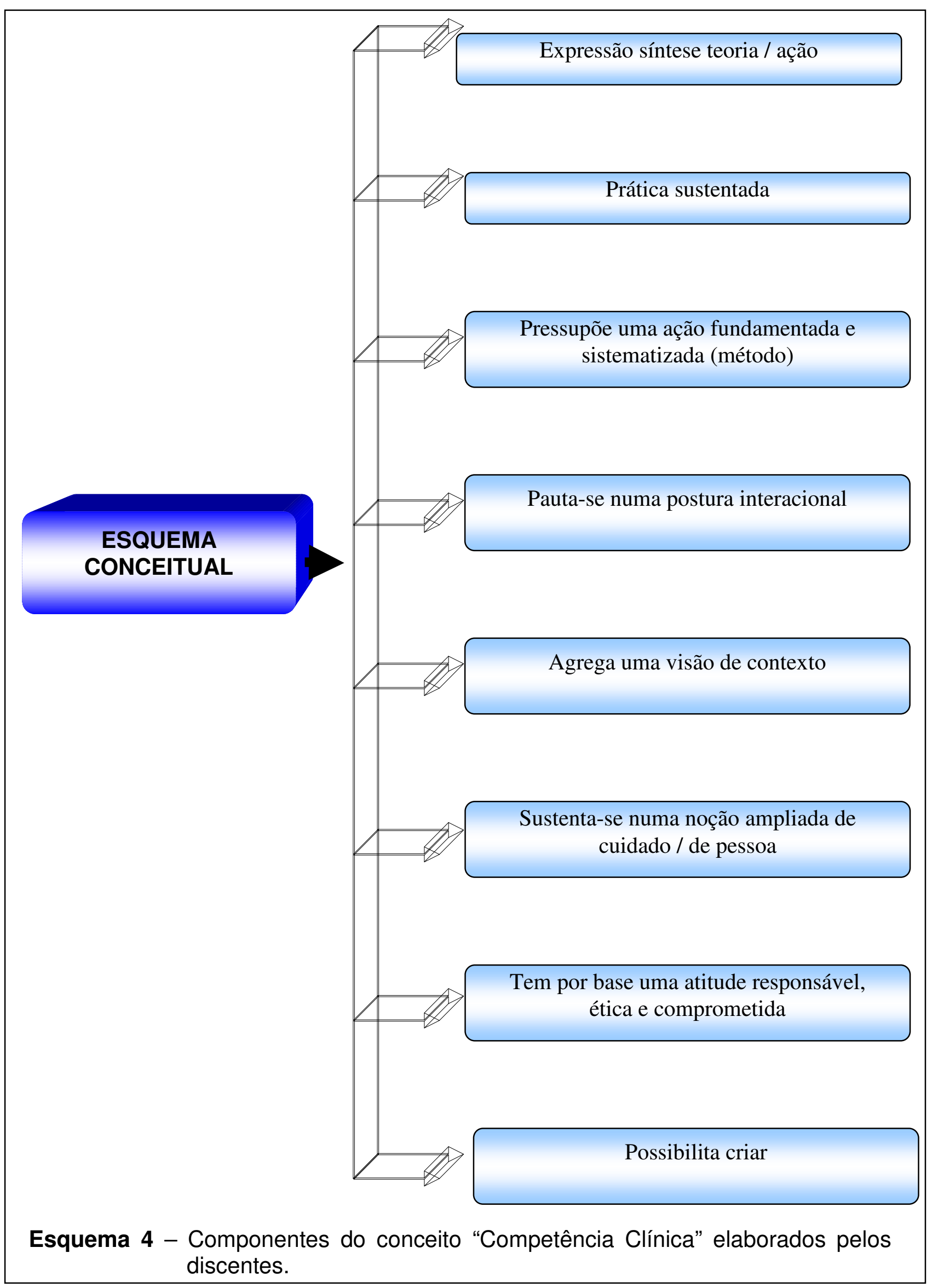


Esse esquema representacional evidencia uma formulação complexa, abrangente multidimensional, compatível com abordagens teóricas atuais, agregando:

- A valorização de saberes, de pressupostos teóricos enquanto elementos e produtos de uma ação sustentada, sistematizada, contextualizada, articulada à realidade;

- A inclusão de uma perspectiva relacional, valorizando o sentido do ser e do cuidar;

- E uma sustentação em princípios éticos, responsáveis, solidários e criativos.

É possível perceber que esses atributos estão relacionados e contêm componentes cognitivos (conhecimentos), afetivos (relacionamento) e condutuais (ações e declarações de intenção). Entretanto a ação clínica parece esvaziada, compondo uma peça-chave aparentemente não elaborada.

Nesse sentido, não se registram evidências da constituição do conceito síntese "competência clínica", demonstrando, talvez, um investimento relativo no seu desenvolvimento através de elaborações teóricas, solução de problemas, experimentação de projetos assistenciais, enquanto estratégias indispensáveis à criação/operação desse conceito em suas múltiplas expressões/perspectivas/ decisões práticas.

Nota-se que, não houve evidências do reconhecimento de competências relativas à construção de hipóteses clínicas; estratégias de verificação; argumentação sobre textos lidos; resolução de problemas clínicos; formulação clara de diagnósticos e proposição de ações enquanto integração e mobilização de múltiplos conhecimentos inerentes ao pensamento/ação clínica. ${ }^{(14)}$ 
De certo modo, emergeria um princípio norteado de uma função social do cuidar enquanto expressão clínica organizada, porém, ainda genérica, que desconsidera inclusive o resultado da ação, como elemento relevante para a constituição da competência.

Assim, "a capacidade de agir eficazmente em um determinado tipo de situação apoiada em conhecimentos, mas sem limitar-se a eles"(14) parece ainda pouco valorizada pelo grupo, prenunciando uma desconsideração pelas formas de realização (mais ou menos eficaz) em situações e tempos reais.

Quando confrontados com os referenciais é possível considerar que o esquema representacional síntese evidencia uma construção de sentido que identifica recursos cognitivos (saberes, ainda que não especificados; o saber-fazer; atitudes) não agregando outros elementos como técnicas, esquemas motores, de percepção, de avaliação, antecipação e de decisão; vem aparentemente dissociada de situações específicas, tarefas, problemas; não explicita a natureza dos esquemas de pensamento que permitiriam a associação, a mobilização a orquestração dos recursos a serem utilizados em situação complexa e em tempo real. ${ }^{(14)}$ Não haveria indicativos da inteligência operativa, ainda que atitudes e posturas mentais tenham sido evidenciadas, conforme atestam os depoimentos referidos a seguir.

\section{Expressão síntese teoria/ação}

"União de todas as áreas: o saber teórico, prático, sabendo relacionar... relacionar para o enfermeiro é essencial..." (7)

“...ter a capacidade e principalmente experiência de relacionar a teoria com a prática... (16)

“...conciliar saber teórico..." (19)

“...relacionar teoria e prática... tomar suas próprias decisões...” (21) 
“...saber relacionar as teorias com a prática... saber o que fazer, como fazer e porquê fazer". (24)

\section{Prática sustentada}

“...saber o que fazer, tomar a melhor decisão em uma situação..." (1)

“...realizar os procedimentos técnicos de forma correta... sempre baseado em princípios científicos..." (6)

“...saber expor na prática os conhecimentos técnicos-científicos, e exercitar o lado humano, e ser crítico e curioso... acima de tudo seguro dos atos". (8)

“...deve ter competência procedimental”. (16)

“...observadora... tomar iniciativa, saber se colocar nas diferentes situações”. (24)

“...planejar as ações de enfermagem...(25)

\section{Postura interacional}

"...além do cuidado considerar o relacionamento do enfermeiro com a sua equipe..." (3)

“...ter bom relacionamento interprofissional, e com o paciente". (9)

"Aceitar as diferenças, trabalhar em equipe, querer aprender mais..." (10)

“...nossa relação com a profissão e com as pessoas que trabalham na nossa área, acima de tudo o gosto e preocupação com o cliente". (13)

“...proximidade e conhecimento do seu paciente, bom relacionamento com a equipe multiprofissional..." (15)

"...é aquele interessado e motivado a cuidar... compreende o paciente como um ser humano com toda sua complexidade individual... que se adapta à estrutura políticoadministrativa... que estuda constantemente... sabe trabalhar em equipe..." (18) "Um bom enfermeiro clínico é saber ser comunicativo, saber ouvir... minimizar a ansiedade do paciente e seus familiares... ter bom relacionamento com a equipe de enfermagem e multiprofissional". (16) 


\section{Atitude responsável, ética e comprometida}

“...ter senso ético e crítico..." (4)

"é o enfermeiro dar assistência ao paciente... respeitar a individualidade, crenças e outros valores". (5)

“...envolver a técnica (prática) e a emoção, intuição e saber... ter ética... cuidar de alguém como se estivesse cuidando de você mesma ou de alguém muito especial. (10) “...profissional capaz de ver o paciente como um todo e de forma humanizada... buscando princípios éticos". (11)

"...a capacidade de cuidar do outro como um todo... aspectos bio, psico-social, independente do motivo de sua internação". (17)

“...ver o cliente com um olhar mais amplo... como um ser humano..." (22)

“...ver o indivíduo como um todo... ter conhecimento para melhor assistir ter sensibilidade de perceber..." (23).

\section{Possibilidade de criar}

“...ter habilidade e versatilidade... criatividade..." (14)

...ser criativo e ético. (15)

...ser bom no que faz... ter habilidade para solucionar problemas, prestar assistência... ter embasamento teórico mas não esquecendo da arte de improvisar..." (27)

“...deve não apenas ter como habilidade a parte científica e conceitual. Precisa estar sempre bem informado... ter paixão pelo que faz..." (29)

\subsubsection{Representações da aprendizagem das competências clínicas}

Continuando a apresentação dos resultados relativos à constituição da perspectiva discente sobre a competência clínica cabe, agora, agregar à conceituação a expressão das representações da aprendizagem nas diferentes disciplinas responsáveis pelo seu desenvolvimento, compondo um sentido de investimento apresentado a seguir. 
Quadro 8 - A construção processual da competência clínica segundo representações discentes. São Paulo, 2004

\begin{tabular}{|c|c|c|c|c|c|c|c|c|c|}
\hline $\begin{array}{l}\text { Introdução à } \\
\text { Enfermagem }\end{array}$ & $\begin{array}{l}\text { Fundamentos de } \\
\text { Enfermagem }\end{array}$ & $\begin{array}{l}\text { Enfermagem } \\
\text { Médico- } \\
\text { Cirúrgica }\end{array}$ & $\begin{array}{c}\text { Enfermagem em } \\
\text { Centro } \\
\text { Cirúrgico }\end{array}$ & $\begin{array}{l}\text { Enfermagem em } \\
\text { Doenças } \\
\text { Transmissíveis }\end{array}$ & $\begin{array}{l}\text { Enfermagem } \\
\text { Pediátrica }\end{array}$ & $\begin{array}{c}\text { Enfermagem } \\
\text { Ginecológica, } \\
\text { Obstétrica e } \\
\text { Neonatal }\end{array}$ & $\begin{array}{l}\text { Enfermagem } \\
\text { Psiquiátrica }\end{array}$ & $\begin{array}{l}\text { Enfermagem } \\
\text { Preventiva e } \\
\text { Comunitária }\end{array}$ & $\begin{array}{l}\text { Administração } \\
\text { em Enfermagem }\end{array}$ \\
\hline $\begin{array}{l}\text { - apresentação da } \\
\text { prática: (suas } \\
\text { transformações; } \\
\text { códigos } \\
\text { normativos) } \\
\text { - invetimentos } \\
\text { procedimentais em } \\
\text { si mesmos } \\
\text { - introdução de } \\
\text { elementos de ética } \\
\text { e humanização }\end{array}$ & $\begin{array}{l}\text { - firma a } \\
\text { perspectiva } \\
\text { procedimental } \\
\text { parcial e } \\
\text { descontextuali- } \\
\text { zada } \\
\\
\\
\end{array}$ & \begin{tabular}{|l} 
- agrega novos \\
conteúdos e \\
práticas \\
procedimentais \\
(código \\
fisiopatológico; \\
SAE; novas \\
técnicas) \\
- articula teoria (ciclo \\
básico) e prática \\
clínica (avaliação / \\
julgamento / ação) \\
- investe na relação \\
dual \\
- agrega o \\
componente ético- \\
legal \\
- utiliza pesquisa \\
- não ensina a \\
coordenação do \\
cuidado
\end{tabular} & $\begin{array}{l}\text { - agrega } \\
\text { competência } \\
\text { procedimental } \\
\text { - percebe o } \\
\text { funcionamento } \\
\text { do CC } \\
\text { - contextualiza a } \\
\text { ação (SAEP) } \\
\text { - amplia } \\
\text { competência } \\
\text { agregando o } \\
\text { componente } \\
\text { relacional e } \\
\text { instrumental } \\
\text { - utiliza pesquisa } \\
\text { - não ensina a } \\
\text { coordenação do } \\
\text { cuidado }\end{array}$ & $\begin{array}{l}\text { - agrega conceitos } \\
\text { específicos à } \\
\text { transmissíveis } \\
\text { - projeta as ações } \\
\text { para saúde pública } \\
\text { - abordagem } \\
\text { humanizada } \\
\text { - não utiliza de } \\
\text { metodologia } \\
\text { assistencial } \\
\text { - não ensina a } \\
\text { coordenação do } \\
\text { cuidado }\end{array}$ & $\begin{array}{l}\text { - traz o binômio } \\
\text { mãe/filho } \\
\text { - agrega conceitos e } \\
\text { procedimentos } \\
\text { específicos à } \\
\text { criança } \\
\text { - adapta a } \\
\text { competência } \\
\text { procedimental às } \\
\text { crianças } \\
\text { - não utiliza de } \\
\text { metodologia da } \\
\text { assistência } \\
\text { - não ensina a } \\
\text { coordenação do } \\
\text { cuidado }\end{array}$ & $\begin{array}{l}\text { - prevenção de } \\
\text { doenças } \\
\text { ginecológicas } \\
\text { - realização do } \\
\text { parto } \\
\text { - avaliação do bebê } \\
\text { e amamentação } \\
\text { - não utiliza de } \\
\text { metodologia da } \\
\text { assistência } \\
\text { - não ensina a } \\
\text { coordenação do } \\
\text { cuidado }\end{array}$ & $\begin{array}{l}\text { - processos } \\
\text { terapêuticos } \\
\text { interacionais } \\
\text { - competências } \\
\text { relacionais } \\
\text { - insere a } \\
\text { família do } \\
\text { doente na } \\
\text { abordagem }\end{array}$ & $\begin{array}{l}\text { - acrescenta a } \\
\text { perspectiva na } \\
\text { ação } \\
\text { preventiva e } \\
\text { educativa } \\
\text { - acrescenta } \\
\text { conceitos } \\
\text { específicos } \\
\text { - amplia o } \\
\text { contexto de } \\
\text { atuação além } \\
\text { do intra- } \\
\text { hospitalar } \\
\text { - não ensina a } \\
\text { coordenação } \\
\text { dos processos } \\
\text { em saúde }\end{array}$ & $\begin{array}{l}\text { - amplia a } \\
\text { possibilidade de } \\
\text { reconhecer e } \\
\text { utilizar famílias de } \\
\text { competências na } \\
\text { prática clínica } \\
\text { - traz a equipe ao } \\
\text { contexto de } \\
\text { atuação }\end{array}$ \\
\hline
\end{tabular}


Quadro 9 - A construção processual da competência clínica segundo representações discentes. São Paulo, 2004

\begin{tabular}{|c|c|c|c|c|c|c|c|c|c|}
\hline $\begin{array}{l}\text { Introdução à } \\
\text { Enfermagem }\end{array}$ & $\begin{array}{l}\text { Fundamentos de } \\
\text { Enfermagem }\end{array}$ & $\begin{array}{c}\text { Enfermagem } \\
\text { Médico- } \\
\text { Cirúrgica }\end{array}$ & $\begin{array}{c}\text { Enfermagem em } \\
\text { Centro } \\
\text { Cirúrgico }\end{array}$ & $\begin{array}{l}\text { Enfermagem em } \\
\text { Doenças } \\
\text { Transmissíveis }\end{array}$ & $\begin{array}{c}\text { Enfermagem } \\
\text { Pediátrica }\end{array}$ & $\begin{array}{c}\text { Enfermagem } \\
\text { Ginecológica, } \\
\text { Obstétrica e } \\
\text { Neonatal }\end{array}$ & $\begin{array}{l}\text { Enfermagem } \\
\text { Psiquiátrica }\end{array}$ & $\begin{array}{l}\text { Enfermagem } \\
\text { Preventiva e } \\
\text { Comunitária }\end{array}$ & $\begin{array}{l}\text { Administração } \\
\text { em Enfermagem }\end{array}$ \\
\hline $\begin{array}{l}\text { apresentação } \\
\text { histórico / } \\
\text { normativa } \\
\text { iniciação em } \\
\text { práticas } \\
\text { procedimentais } \\
\text { inserção de } \\
\text { componentes } \\
\text { ético e } \\
\text { relacionais }\end{array}$ & $\begin{array}{l}\text { - iniciação em } \\
\text { práticas } \\
\text { procedimentais }\end{array}$ & $\begin{array}{l}\text { - cuida } \\
\text { - comp } \\
\text { - aplica }\end{array}$ & $\begin{array}{l}\text { o dual como } \\
\text { eensão de co } \\
\text { ão e exercita }\end{array}$ & sco & specíficas & a sistemat & zada & & $\begin{array}{l}\text { • exercita a } \\
\text { clínica } \\
\text { • insere a prática } \\
\text { dual no conjunto } \\
\text { das ações intra e } \\
\text { multiprofissionais } \\
\text { • potencializa a } \\
\text { tomada de } \\
\text { posição } \\
\text { - reconhece } \\
\text { implicações da } \\
\text { ação } \\
\text { - problematiza a } \\
\text { prática coletiva e } \\
\text { instituída, foca a } \\
\text { coordenação do } \\
\text { cuidado em } \\
\text { tempo real }\end{array}$ \\
\hline
\end{tabular}


O modo como esse grupo entendeu e representou a aprendizagem da competência clínica nas diferentes disciplinas assistenciais do curso, constitui importante e complexa fonte de informações acerca da formação do enfermeiro para a prática assistencial.

Preliminarmente, caberia considerar que a iniciação temática aconteceria a partir de abordagens concretas voltadas à inserção da Enfermagem no cenário das práticas em Saúde, trabalhados numa perspectiva histórica, à vinculação do exercício a códigos ético-normativos pré estabelecidos, culminando na valorização do desempenho procedimental esvaziado de sentido e aplicação.

Assim, a introdução e a fundamentação teriam por foco uma prática reduzida, distante dos referenciais teóricos relacionados à compreensão do ser, do cuidar, da emergência das emoções e significações presentes nessa interação. Aspectos das pessoas em relação a dos contextos específicos como partes inseparáveis do processo terapêutico não teriam sido considerados.

Outro vazio teórico aparente relaciona-se a uma iniciação que não estaria explicitando sua perspectiva de conhecimento, sua relação com a reflexão científica, sua vinculação a uma prática sustentada por evidências, enfim, sem referencial explicitado de ciência.

Para esses alunos, o cuidar teria sido introduzido limitando-se a circunscrições procedimentais exercitadas de forma impessoal, única e dissociada de outras perspectivas.

A especificidade do papel profissional do enfermeiro como coordenador do cuidado, assim como a necessidade de instrumentalizar sua ação assistencial tendo por base o raciocínio clínico como precursor da tomada de decisão imprescindível à essa função, atribuindo um sentido e uma funcionalidade ao 
conjunto de ações de enfermagem também pareceram ausentes do repertório apresentado pelo grupo.

Assim o diálogo, entre pressupostos teóricos e experiência prática não teria sido apresentado, muito menos problematizado.

Dessa forma, a representação de aprendizagem que emerge reduziria os percursos possíveis à valorização performática de "procedimentos básicos", distante dos preceitos inerentes ao desenvolvimento dessa aprendizagem, ou seja:

- A reflexão sobre a própria atividade, possibilitando a consciência da atuação, da sua sustentação teórica, da sua funcionalidade; do seu sentido. Nessa perspectiva, o termo "básico" deixaria de ter sentido por pressupor embasamentos e reflexões complexas, ainda que não "invasivas" enquanto condição talvez presente nessa construção de sentido; ${ }^{(19)}$

- A aplicação em contextos diferenciados, em situações nem sempre previsíveis, superando sua transferência para outros contextos quase que mecanicamente. ${ }^{(19)}$

Os discursos que ilustram estas construções teórico-prático são:

“Introdução... início da aprendizagem teórico-prático” (5)

“...foram enfocados somente técnicas... muitas vezes deixando de lado o relacionamento com o paciente”. (7)

“Introdução - História da Enfermagem... conceitos básicos. (11)

“...estágio no Asilo... SSVV e um pouco sobre anamnese. Valorização do ser humano".(9)

“...aprendi apenas a ver o paciente como um objeto de estudo...” (22) 
"Fundamentos, apenas técnicas". (3)

“..ênfase aos procedimentos...(4)

“....só aprendemos as técnicas”. (13)

"Fundamentos... não nos preocupamos com o todo e sim com uma medicação apenas...(17)

“...mas com algumas preocupações a mais, administrar medicação, dar um bom banho.(22)

"A cobrança é mais ligada à parte técnica... deixou a desejar em alguns aspectos". (29) "Introdução à Enfermagem faltou as teorias de Enfermagem... em Fundamentos ficamos um mês e meio realizando técnicas... e não aprendemos a pensar, o que posteriormente em Médico-Cirúrgica tivemos que aprender a pensar e relacionar teoria e prática". (3)

A continuidade dos investimentos na aprendizagem da competência clínica pode ser analisada em conjunto na medida em que as representações discentes abordam investimentos comuns a elas, ou sejam: o foco no cuidado dual específico, aquele que aproxima um estudante e um paciente, com maior ou menor consideração pelo seu contexto e integralidade; a inclusão de conceitos/ações específicas à cada área/disciplina, com maior ou menor investimentos na articulação dessa especificidade às demais enquanto responsabilidade comum; a retomada de conteúdos das ciências "básicas" como base para a ação clínica; o investimento em técnicas específicas de área/disciplina.

A utilização de referenciais metodológicos para a sistematização da ação clínica não parece ser apreendida como um investimento em todas as disciplinas, promovendo uma descontinuidade preocupante a medida em que a especificidade de atuação não abdica de investimentos metodológicos comuns.

Repete-se, nessas representações a valorização do investimento procedimental relativo. A aprendizagem conceitual não parece refletir: processos de 
elaboração e construção pessoal de conceitos e princípios; atividades que favoreçam relações e um sentido de funcionalidade aos novos empreendimentos. ${ }^{(19)}$ Conteúdos atitudinais também não estariam presentes nessas representações na medida em que essa aprendizagem pressupõe:

- "Um conhecimento e uma reflexão sobre os possíveis modelos, uma análise e uma avaliação das normas, uma apropriação e elaboração do conteúdo, que implica a análise dos fatores positivos e negativos, numa tomada de posição, um envolvimento afetivo e uma revisão e avaliação da própria atuação".(19)

Para ilustrar a discussão apresenta-se os discursos dos discentes referentes às representações nominando as disciplinas ou reportando-se sobre o aprendizado geral no grupo de disciplinas, de acordo com as falas a seguir.

“...correlação dos procedimentos e a teoria, ênfase na crítica, na ética e na pesquisa, relacionamento, convívio".(4)

“...visão do paciente como um todo...”(5)

“...consolidou-se o saber técnico associado ao saber científico, o porquê.."(6)

“...SAE, assistência integral... Estudo de caso, aperfeiçoamento das habilidades, relacionamentos". (9)

“...começamos a ter a noção do todo; chegávamos e cuidávamos de um paciente por completo. Sabíamos suas ansiedades... interagíamos com a família..."(17)

“...Médico-Cirúrgica... como um todo, o paciente mas não a conhecer a enfermaria...”(21)

“...aprendi muito nesta disciplina... fiz meu primeiro trabalho científico..”.(24)

“...modo de funcionamento do C.C...." (5)

“...novas competências técnicas... (6)

“...esterilização, instrumentação, SAEP”. (13) (15)

“...valor a humanização, SAEP, instrumentação, etc.” (19) 
“...Centro cirúrgico - o antes e o pós-operatório”. (20)

“...vimos um único paciente e ainda não participamos da real atuação da enfermeira.(21)”

“...procedimentos de alto risco...” (4-19)

“...olhar para Saúde Pública surge em Transmissíveis...” (6)

“...humanização...” (8)

“...percebe-se ainda mais o quanto é importante e preciso utilizar as precauções padrão".(11)

“Transmissíveis-novas patologias..” (13)

"DT, isolamentos, novas doenças". (15)

"Em DT comecei a sentir falta da SAE... fica mais fácil... conhecermos, planejar a assistência. (17)

"DT vimos um único paciente e ainda não participamos da real atuação da enfermeira".(21)

“...ênfase em EPI...(24)

“..ênfase no convívio mãe/filho, procedimentos específicos, pesquisa”. (4)

“...transpor o conhecimento em Saúde do Adulto para o universo da criança e todas as suas peculiaridades - nasce a competência da adaptação”.(6)

“...conhecimento científico técnico e humanização”. (8)

“...desenvolvimento da criança... as diferenças entre criança e adulto”. (15)

“...apenas aquela criança e não a enfermaria, não a real atuação da enfermeira”. (21)

“...como lidar com o paciente pediátrico”. (26)

“...Ginecologia e Obstetrícia patologias específicas, partos e ênfase na amamentação..."(1)

“...mecanismo do trabalho de parto e o próprio parto, ensinado na teoria e filmes e a emoção do "ao vivo"... fazer o parto..."(6)

“...ao passar também na maternidade avaliar o bebê e orientar a mãe para a amamentação, além de ter visto nos livros..."(17)

"Preventiva e Comunitária: áreas sociais, trabalhos junto à comunidade”(3)

“...revisão de saúde como um todo, processo, procedimentos, atuação”.(7)

“...ação preventiva e educativa aos pacientes”(5) 
“...prevenção e orientações... relacionamento. Todas as áreas já aprendidas”(9)

“...questões educativas com a população...”(15)

“...perdeu-se um pouco a noção da capacidade de cuidar da pessoa...(17)

“..diversas áreas, mas também não vimos a unidade como única”(21)

“...senti dificuldades em Psiquiatria...”(4)

"Psiquiatria: nas interações se faziam caminhadas, danças... recreação"(9)

“...assistimos muitos filmes e através deles discutimos os conteúdos”(13)

Vale salientar, ainda que essa representação atrelaria o graduando a uma performance procedimental compatível com a formação de nível médio uma vez que o raciocínio clínico e a tomada de decisão indicativa do planejamento assistencial do conjunto de pacientes / clientes não estaria presente nessa construção de sentido.

Nesse sentido, reconhecendo a complexidade do conceito de competência e a forma imbricada e intensa que as disciplinas assistenciais precisariam apresentar-se para a constituição dessas competências, para compor o ser enfermeiro, destaca-se o conceito de processo de cuidar definido por Ide, Chaves ${ }^{(68)}$ enquanto "seqüência dinâmica e sistematizada de ações necessárias e suficientes para a construção, desempenho e validação do trabalho da equipe de enfermagem, agregando intervenções específicas (cuidar dual), ações complementares e interdependentes do conjunto multiprofissional (assistir-cuidar) desenvolvidas em contextos institucionais peculiares".(68)

Nessa dinâmica de trabalho a enfermeira assistencial tem por competência a coordenação do processo de cuidar e como instrumentos a sistematização do cuidar, a mediação das relações profissionais e a representação da sua equipe junto às esferas de gestão, interface com o processo de trabalho de administrar. $^{(68)}$ 
É possível considerar que essa competência estaria sendo acessada na disciplina de Administração em Enfermagem por eles trazida à composição das experiências clínicas. Esse foi o espaço por eles associado: ao exercício da clínica; à superação da relação dual e dissociada do conjunto; ao reconhecimento do conjunto e do contexto; a percepção da repercussão da ação; à problematização da dinâmica de uma prática coletiva e instituída.

Nesse sentido, o código administrativo, as bases teórico metodológicas da prática da gestão do processo de trabalho estariam sendo mescladas à coordenação do processo de cuidar, evidenciando construções de sentido ainda inespecíficas, conforme os depoimentos referidos a seguir.

"Cada disciplina tem sua contribuição à nossa formação. Vimos a teoria do ciclo básico... Vimos os primeiros conceitos de enfermagem e técnicas. Em Médico-Cirúrgica atendimento integral ao paciente... família. Em MI apareceu a questão do respeito em contraste com o preconceito. Em Saúde Pública o contato com o sadio, a prevenção... quando cheguei em Administração foi que apareceu a ligação de tudo... começando a costurar uma colcha de retalhos..."(28) "ao final do $4^{\circ}$ ano percebemos um leque de competências e a vontade imensa de desfrutar..."(6)

Vale acrescentar às representações voltadas à caracterização do sentido da aprendizagem clínica uma dimensão relativa às sensações mobilizadas nessa experiência, identificando fatores intervenientes.

Os depoimentos discentes apontam como aspectos facilitadores da aprendizagem: o caráter gradual desse investimento; uma postura docente receptiva e facilitadora, facilitando a interação e o desenvolvimento. 
"As competências clínicas foram dadas de maneira gradual... base teórica e aos poucos ensinando que éramos capazes de tomar a melhor decisão" "...foi um aprendizado contínuo e crescente... nos sentíamos mais capazes de realizar os procedimentos com competência".

“...ensinadas de forma gradativa, sempre tendo como instrumento o estudo de caso e as discussões no final do estágio diário" ".... aprendizado foi de forma gradativa e muitas vezes de acordo com oportunidades..."

"...foi passado gradualmente... competências relacionadas ao ser enfermeiro foi fundamental à formação..."(6)

“...fui amadurecendo e crescendo... acredito ter seguido a lei natural "quanto mais velho mais experiente... foi um aprendizado gradativo..." (22)

"O processo de aprendizagem foi tranqüilo... tinha professores comprometidos com o ensino..." (4)

“...o que foi bom... ser incentivada a ser crítica, humana e sempre estar embasada cientificamente antes de discutir um caso". (8)

“...quando o docente mostra confiança...” (9)

“...professoras sempre disponíveis... passam segurança...” (11)

“...bons docentes e a maneira bastante acessível..." (25)

"Facilidades - ter bons professores..." (26)

Os aspectos negativos tiveram como foco: o caráter fragmentado da abordagem; uma tomada de decisão às vezes automática; pouco consenso entre docentes; a ênfase procedimental, excesso de pressão sobre os alunos; a exposição à situações de risco (DT); um distanciamento teórico-prático referido como problemático; um distanciamento docente-discente; poucos espaços de experimentação criativa. 
Essas reações valorativas evidenciariam um investimento em tornar menos tensas as situações de aprendizagem, valorizando atitudes docentes que promovessem "bem estar", menos desgaste, menos tensão. As atitudes refutadas disseram respeito à posturas representadas como autoritárias, distantes, passíveis de colocar em questão uma segurança frágil para o desenvolvimento de ações aparentemente além da possibilidade da maioria dos estudantes.

Não se evidenciou representações voltadas a uma interação aberta aos desafios, potencializadora de conflitos cognitivos, direcionado para uma autonomia aparentemente não requerida nem pelo docente nem pelo discente.

Reitera-se, assim, uma relação interativa estruturada no sentido do resultado da ação, visando a realização controlada pouco permeável à negociação, participação e construção partilhada.

Nessa pactuação, os investimentos teriam por finalidade poupar energia criativa na medida em que a tensão decorrente da superação dos obstáculos à prática do cuidar por si mesma já promoveria tensão e sofrimento psíquico, ora atenuado ora potencializado pela presença docente.

"Falta integração entre as disciplinas". (9)

“...falta humanizar por parte dos professores”. (10)

“...as dificuldades também foram as interrelações das matérias, que achávamos difícil, conseguíamos fazer, mas que no final eram automáticas às tomadas de decisões". (1)

“...falta interação entre as disciplinas”. (3)

"Foi um aprendizado gradual, mas falta integração entre as disciplinas... continuidade entre as matérias... alguns estágios nem os professores entram num consenso". (19)

“Um fator negativo foi a falta de integração entre as disciplinas”. (27) 
"encontrei em todas as disciplinas relacionadas à Saúde do Adulto as professoras focalizaram um conteúdo de trabalhos realizados por estas na Pós-Graduação... e não deram a devida importância a conteúdos que dizem respeito à disciplina... percebi ao prestar o Provão que havia questões básicas... não foram explicadas...” (12)

"Introdução à professora foi um facilitador; Fundamentos que significa a nossa porta de entrada na profissão... mas a maneira estressante e com muita pressão... acaba sendo traumático...; médico-cirúrgica... começa a se mostrar que o cuidar envolve muito além de uma técnica; Centro Cirúrgico não tive problemas; D.T. foi pesado pela transmissibilidade... e a supervisão também não era muito cooperativa". (15)

"Todas as disciplinas relacionadas à Saúde do Adulto me fizeram aprender muito. ...dificuldades até se sobressaíram... Ml com doenças raras, medicações que não conhecia... (22)

"Nas disciplinas, não em todas, mas senti certa distância dos professores..." (3)

..."em geral não tive dificuldades de aprendizado... é maior a dificuldade de relacionamento com alguns professores, enfermeiras e trabalhadores da área de saúde".(13)

“...tranqüilo exceto nas situações em que alguns docentes não abriram espaço para discussão de técnicas a serem executados, ...simplesmente decoradas". (18)

Essas representações reforçam os investimentos já analisados e as representações que trazem no sentido de perspectivas uma formação ainda pouco disponível para a inovação considerando referenciais pedagógicos, inclusive valorizadas e destacadas nas Diretrizes Curriculares Nacionais ${ }^{(16)}$ que colocam, como já foi referido, as atividades complementares a serem incrementadas durante todo o Curso de Graduação em Enfermagem, criando mecanismos de aproveitamento de conhecimentos, adquiridos pelo estudante, através de estudos e práticas independentes presenciais e/ou a distância. Esta flexibilidade tem sido pouco utilizada numa estrutura curricular planejada aprioristicamente, com atividades atreladas quase que somente à práticas supervisionadas de forma direta. 


\subsubsection{Representações discentes relacionadas à expressão da competência clínica na prática}

Finalizando esse núcleo temático cabe, agora acrescentar a esses conteúdos ideativos o reconhecimento de expressão de competência clínica, tendo a representação da prática assistencial dos enfermeiros como referência.

Esses depoimentos trazem como elementos constitutivos comuns, a percepção de uma atuação vinculada a uma lógica burocrático-administrativa que muitas vezes sobrepuja a lógica clínica.

Alunos representam enfermeiros como profissionais atrelados aos papéis, às coisas, distanciando-se do cuidado dual e da coordenação do cuidado.

“...a realidade deixa muito a desejar... a maioria das enfermeiras cheia de papéis na mão, com telefonemas... ocupa quase todo tempo... distanciamento do paciente. $O$ essencial é deixado de lado". (15)

"Na graduação aprendemos principalmente o diagnóstico, planejar e implementar as ações de enfermagem e também a lidar com a parte burocrática... o enfermeiro de campo lida em sua maior parte do tempo com atividades burocráticas..." (25)

Também não se evidenciam nessas representações expressões de uma competência administrativa específica; o enfermeiro não foi percebido como responsável pela dinâmica de trabalho da clínica, tendo sido representado como alguém vinculado à burocracia.

“...a prática é bem diferente da teoria... há limites mas podemos realizar um brilhante trabalho com o que temos". (1) 
"A maioria dos enfermeiros estão voltados para a parte burocrática... são poucos os que estão ao lado do paciente... familiares..." (7)

Esses depoimentos reiteram o caráter idealizado pela formação uma vez que o anunciado elo para ser competente parece não estar presente no desempenho percebido na realidade de trabalho dos profissionais.

"É muito diferente o que aprendemos na graduação com a prática do enfermeiro de campo... os enfermeiros são mais administrativos do que assistenciais..." (13)

“...aprendemos a fazer o correto, o teórico, o pesquisado, o estudado; porém não aprendemos o real, o prático. Não vemos realmente como a enfermeira pode atuar, ...como deve..." (21)

"O enfermeiro muitas vezes com a desculpa de excesso de trabalho deixa de exercer suas competências ficando mais com a parte administrativa..."(2)

“...enfermeiro nos campos de estágio que não mostram competência clínica.. não fazem cursos de especialização ou aperfeiçoamento, não fazem pós-graduação... talvez por acúmulo de serviço, mas não acredito que justifique”. (3)

“...são mais desenvolvidos na graduação...” (10)

“...bem diferente o que nós aprendemos na teoria... Elas não dão conta da burocracia enorme... não sobra tempo para a assistência..." (16)

“...dificuldades e as limitações impostas pela instituição ao enfermeiro desestimula sua atuação... todos os enfermeiros sabem como fazer... no entanto não são todos que encontram forças internas e externas para concretizá-la”. (18)

Esses resultados coincidem com achados de outras pesquisas, nas quais essa inserção profissional, em descompasso quando comparado com o oferecido na graduação, também se fez presente. 
Matheus $^{(8)}$ considera a dificuldade da recém-formada ao buscar sua inserção no local de trabalho, inclusive por questões de aprendizagem e realinhamento de valores, atitudes e comportamentos; porém descreve a vivência como um embate entre os sistemas de referência. Destaca que o que foi construído durante a formação, relativo a conceitos, princípios, atitudes e ações, e o relativo à demanda de trabalho, fazendo desta fase, uma experiência complexa. Traz também um caráter revelador, tanto no aspecto do re-conhecimento do papel da enfermeira num hospital, como no de perceber-se uma pessoa diferente e capaz, na medida do possível e do preconizado.

Com resultados similares aos encontrados neste estudo quando referem-se ao papel das Escolas de Enfermagem propondo um ensino controvertido do ensinar uma enfermagem desvinculada da realidade, em vários aspectos, citado também por Vargens. ${ }^{(11)}$

O descompasso referido pelos alunos entre a formação em nível superior e o que é vivido na prática, foi discutido por pesquisadores como Vargens ${ }^{(11)}$; Martins $^{(55)}$; Ide, Chaves ${ }^{(69)}$; Angelo ${ }^{(70)}$, dentre outros, que destacam em seus estudos esta incompatibilidade pautada em investimentos pedagógicos desvinculados da realidade do desenvolvimento do aluno, incluindo os referenciais teóricos utilizados, a falta de delineamento do perfil e das competências, a própria organização do processo de ensino numa estrutura curricular engessada e a falta de investimento em novos pactos de relacionamento escola-campo. Estes são alguns elementos que mereceriam importância numa discussão ampliada.

Cabe acrescentar a essa análise o fato dos graduandos utilizarem como justificativas dessa expressão profissional, conforme discursos já referidos, a força da instituição; o excesso de trabalho; um despreparo; dentre outras circunstâncias 
que relativizariam o espaço da responsabilidade individual, da intencionalidade dos profissionais pelas opções assumidas.

Essa postura prenuncia uma atitude defensiva que referenda uma força externa em detrimento da autoria da própria performance, atitude também já identificada em outros trabalhos.

Püschel ${ }^{(71)}$, considera que representações de enfermeira acerca de desejar um papel privilegiado, com projeção institucional ampliada, ainda parece tímida, em seus achados, sugerindo pouca elaboração para nova expressão do ser enfermeiro. A formulação para o novo estaria contida ainda no espaço, no tempo e no desejo da existência instituída. Os esquemas representacionais em síntese, identificam investimentos atrelados à externalidade, com pouca mobilidade na dimensão intrapessoal, como substrato para essas mudanças.

Assim, na inserção desses profissionais no mundo do trabalho também em estudos de Martins ${ }^{(55)}$ e Matheus ${ }^{(8)}$ as autoras identificaram investimentos que vêm carregados de sofrimento, tristeza, ansiedade; mostra uma construção de defesas agregando, a estes mecanismos, os fatores causais postos no externo.

Finaliza-se, portanto, os conteúdos que trouxeram à teoria as construções ideativas resultantes da aprendizagem da competência clínica nessa graduação, valendo relacioná-las, agora, à uma perspectiva avaliativa, tendo o incidente crítico como estratégia de análise. 


\subsection{O incidente crítico como estratégia de análise da aprendizagem clínica}

Esta etapa do estudo foi desenvolvida no sentido de evocar situações de aprendizagem clínica ocorridas no decorrer da graduação e que, por diferentes motivos, foram consideradas significantes para o grupo.

Buscávamos indicativos do desenvolvimento de competências, incluindo "saberes, capacidades, microcompetências, informações, valores, atitudes, esquemas de percepção, de avaliação e de raciocínio" mobilizados pela cena relevante. ${ }^{(31)}$

Assim essa reedição poderia evocar, junto com os eventos em si, "observações, surpresas, sucessos e fracassos, medos e alegrias", culminando na identificação de novos investimentos de formação. Serviria para "mobilizar aquisições prévias, diferenciá-las, contextualizá-las”, funcionando como um procedimento avaliativo da aprendizagem. ${ }^{(31)}$

Essas retraduções seriam, nessa concepção, indicativos da constituição do ser estudante e da sua relação simultânea com a cultura, com o ambiente e com as relações acadêmico-assistenciais. Nessa perspectiva, lembranças ativadas pela memória tornar-se-iam presentes, recombinando-se, evocando uma noção de acontecimentos em reorganização, capazes de enunciar saberes da experiência. Tais saberes "não provêm da formação inicial e nem mesmo da contínua; são constituídos ao longo da prática por meio da acumulação ou da formação de novos esquemas de ação".(31)

Em síntese, buscou-se finalizar esta pesquisa utilizando o incidente crítico como estratégia voltada à apreensão de situações que estudantes tiveram que resolver, incluindo os dilemas experienciados, as decisões tomadas, os gestos que 
realizaram, compondo um significante conjunto de informações apresentadas a seguir.

\subsubsection{A natureza das experiências}

Todos os estudantes envolvidos referiram incidentes críticos vivenciados em diferentes etapas da graduação. Apesar de estarem no $4^{\circ}$ ano, rememorizaram experiências ocorridas: em todos os tempos da aprendizagem clínica, incluindo situações inerentes à disciplina de Administração em Enfermagem, marcadas por dilemas por eles inseridos no contexto assistencial. Assim, dos 29 incidentes referidos:

- 8 ocorreram no $2^{0}$ ano, 10 no $3^{\circ}$ ano e 11 no último ano da graduação;

- no $2^{\underline{0}}$ ano, 3 aconteceram na disciplina de Fundamentos de Enfermagem e 5 em Enfermagem Médico-Cirúrgica;

- no $3^{\circ}$ ano, a distribuição compreendeu todos os âmbitos da Enfermagem, incluindo a Obstetrícia (2), a Pediátrica (2), Centro Cirúrgico (3) e Doenças Transmissíveis (3);

- no $4^{0}$ ano, houve a caracterização de 8 situações clínicas marcantes, ocorridas no estágio de Administração em Enfermagem, e 3 experiências vivenciadas em Enfermagem Psiquiátrica.

No conjunto essas reapresentações vêm marcadas: pela noção de limite, de dificuldade, de árdua superação no sentido da operacionalização de ações 
pontuais, quase sempre de caráter procedimental; de conflitos entre posturas "adequadas" e "inadequadas"; de exercícios de auto-estima reforçadas pela valorização externa; de problemas de inserção no contexto e no conjunto das interações clínicas. Situações prazerosas, pautadas em êxito, iniciativa, criatividade foram significativamente menos referidas. A síntese desses resultados encontra-se referido a seguir, após as falas que expressam esses conteúdos.

"Fomos dar banho... ele gritava de dor... aprendemos que deveríamos perguntar ao paciente se ele tinha coisas de uso pessoal... mas não disseram para avaliar o contexto. O motivo de não analisar o contexto e fazer algo errado... o professor ficava apenas observando... demorei muito tempo para realizar... não sabia direito o que fazer, e quem acabou sofrendo foi o paciente".(21)

“...aprendemos a realizar o curativo com determinados materiais... na enfermaria não tinha tesoura estéril e peguei uma lâmina de bisturi... Comecei o procedimento... na hora de cortar a gase que ficava no curativo e que nós fazíamos com tesoura, eu não conseguia cortar com a lâmina... minha colega pergunta se a docente não poderia me ajudar... Eu que já estava nervosa, não parava de tremer e foi então que a docente falou em tom alto e repreendedor! Pare de tremer!! Depois de uns quinze a vinte minutos consegui terminar o curativo do intracath". (27)

"Pedi a paciente que ficasse tranqüila pois iríamos ajudá-la a amamentar e também pedi a Deus que nos ajudasse naquele momento. Assim colocamos o bebê para mamar e nada... nada... nada aí ele começou a chorar novamente, e a mãe junto. Acalmamos novamente mãe e bebê e por fim, o bebê começou a mamar... Pedi a Deus que me desse tranqüilidade... a enfermeira também manteve-se serena durante todo o tempo".(17) 
...Sala de Politrauma... uma jovem de 22 anos, estado grave... começou o atendimento seguindo os padrões do ATLS, com toda equipe integrada e treinada. A jovem tinha fratura de mandíbula e maxilar além de muito sangramento... intubação... acesso venoso... choque... bolsas de sangue... ringer aquecido... tomografia... vários procedimentos médicos que a equipe de enfermagem tem grande atuação... todas especialidades foram chamadas... Cheguei me paramentei como todos os outros da equipe, médicos, enfermeiros, auxiliares... Eu fiquei junto aspirando e manuseando algumas pinças... ajudei a fazer outras imobilizações... fiz o exame físico neurológico junto com o residente... E pensei, e se fosse comigo? Quando o pai dela chegou... o que será que passou na cabeça e no coração desse senhor? ...

Quadro 10 - Caracterização dos incidentes críticos segundo a natureza dos eventos. São Paulo, 2004

\begin{tabular}{|c|c|c|}
\hline $2^{\circ}$ ano & $3^{\circ}$ ano & $4^{\circ}$ ano \\
\hline $\begin{array}{l}\text { Desenvolvimento do fazer/ } \\
\text { saber-fazer / procedimentos }\end{array}$ & $\begin{array}{l}\text { Desenvolvimento do } \\
\text { fazer / saber-fazer novos } \\
\text { procedimentos }\end{array}$ & $\begin{array}{l}\text { Problemas interpessoais } \\
\text { - trabalho em equipe: } \\
\text { referências/sentido }\end{array}$ \\
\hline \multirow{3}{*}{$\begin{array}{l}\text { - adequação dos tempos } \\
\text { - reação do doente } \\
\text { - convívio com a morte }\end{array}$} & - Transposição (com êxito) & - Espaços de auto-expressão \\
\hline & & $\begin{array}{l}\text { - Capacidade de atuação } \\
\text { - doente / familia / equipe }\end{array}$ \\
\hline & & $\begin{array}{l}\text { - Convívio em situações } \\
\text { complexas } \\
\text { - atendimentos em equipe } \\
\text { - situações inéditas } \\
\text { - possibilidades de iatrogenia }\end{array}$ \\
\hline (Foco - Procedimental) & (Foco - Procedimental) & (Foco - Atitudinal) \\
\hline
\end{tabular}

A análise desses dados possibilita múltiplas interpretações Preliminarmente, é possível considerar que a maioria dos incidentes tem por foco situações pontuais que teriam sido marcantes, provavelmente, pelo descompasso entre o prescrito e o viável, considerando a competência discente para a realização 
de atividades de aprendizagem supostamente adequadas ao seu nível de desenvolvimento.

Assim, a configuração da situação de partida pouco evoluiu no sentido de agregar indicativos de planejamentos, adequação do plano, articulação dos fatos, sustentação teórico complementar, alternativas de enfrentamento subsidiando novas propostas de intervenção. Houve uma construção de sentido hegemônica tendo como cerne dificuldades de desempenho em si, desde os básicos (sinais vitais, banho, curativos) até os mais específicos / complexos (parto, aspiração, abordagem de paciente agressivo, atendimento em parada cárdio-respiratória, amamentação). $\mathrm{Na}$ apresentação dos fatos não foram evocados conceitos, nem associação de dados, nem mesmo uma compreensão ampliada dos eventos e suas circunstâncias. As falas exemplificam estas experiências.

"Na UTI... eu iria dar meu primeiro banho no leito... um odor horrível... o paciente tinha evacuado antes de iniciar o banho e a professora orientou para manipular o mínimo pois ela era cardíaca... dividimos as tarefas e eu fiquei com o banho... entrou o residente, docente e falou - Nossa porque esse bando de gente para dar um banho! ... foi horrível naquele momento eu estava passando por cima de muitas coisas..." (11)

"Era o $1^{\circ}$ dia de estágio... chegamos no CAPS, ficamos um pouco perdidas... Fiquei pasma a Sta. $M$ veio em direção a mim e me abraçou. Como? pessoa que eu não conhecia e a paciente tão amigável... Houve uma dinâmica, eu fiquei observando, no final a Sra. M desabafa em choro a morte do seu irmão há 7 anos. Naquele momento nenhuma psicóloga tenta acalmar ou interagir com $M$ que acabou ficando agressiva. Todos saíram da sala e M ficou chorando a morte do irmão. Eu não sabia como abordar..."(20) 
A singularidade desses enunciados poderia evocar um estilo culturamente adquirido de expressão e de registro de pensamentos e ações que revelariam aspectos da capacidade de abstração desses estudantes, a maneira como eles estariam organizando seu mundo, incluindo: idéias, conhecimentos, concepções, ações, crenças, princípios, juízos, predisposições para atuar, condutas de acordo com valores, padrões de comportamento pactuados dentre outros componentes do seu estilo de ser estudante.

Nessa perspectiva, a análise dos conteúdos não identificou atributos como dedução, compreensão, evolução de noções, interpretações de casualidades enquanto elementos constitutivos do pensamento lógico. As descrições pelo contrário, vieram organizadas numa relação linear, de causa e efeito, tendo como cerne, experiências de atuação procedimental, inserção e relação interpessoal.

Apesar do grupo discente ter se caracterizado por iniciativas de aprimoramento (iniciação científica, cursos de línguas, de informática, dentre outras aquisições), por investimentos relacionais, e uma atuação voltada para os dispositivos do mercado de trabalho, compondo indicativos de um desenvolvimento pessoal em sintonia com as prerrogativas de uma formação superior, os conteúdos ideativos registraram um desenvolvimento cognitivo truncado.

Esse estilo de expressão poderia incluir tanto os hábitos mentais pregressos quanto os mobilizados pela Graduação. Tendo o sistema formador como foco, é possível questionar o sentido de desenvolvimento da competência procedimental uma vez que, para a maioria dos estudantes, sua expressão veio marcada pelo "dar conta" configurando uma apropriação reducionista de desempenho. Numa perspectiva construtivista, "trabalhar os procedimentos significa revelar a capacidade, no aluno, de saber fazer, de saber agir de maneira eficaz".(23) 
Na medida em que as situações referidas possibilitam a identificação de um sentido de aprendizagem pautado no resultado, na performance vivenciada com dificuldades, limites e sofrimento, é possível considerar que os diferentes graus de conhecimentos e habilidades discentes, foram pouco analisados, não prenunciando o estabelecimento de níveis de desafios e ajudas adequadas ao desenvolvimento de cada estudante.

Assim, hipoteticamente, a Graduação formaria uma superestrutura sobre o desenvolvimento desses alunos, as referências continuariam pautadas no conteúdo e nos objetivos disciplinares, realidade exterior àquele que aprende, compondo experiências marcantes no sentido da pertinência, da reprodução, da tentativa de adequação às exigências dos docentes, dos profissionais dos campos de prática, dos doentes, dos familiares, enfim, "dos outros".

Por outro lado, torna-se necessário reconhecer a peculiaridade da bagagem pregressa desses alunos. Para os construtivistas, os conhecimentos (incluindo o estilo de pensar e de agir) prévios trazidos pelos estudantes têm por características:

- "a construção pessoal; procurar a utilidade mais do que a "verdade"; possuir um caráter implícito (descobertos em atividades; ações); serem estáveis e resistentes à mudança; possuir coerência do ponto de vista do aluno, não do ponto de vista científico".(23)

Assim, esse estilo de valorizar, reagir e recompor situações culturais decorreria, hipoteticamente do sinergismo entre uma unidade de estilo própria da trajetória pessoal na interface com a cultura do curso. Essa combinação funcionaria como elemento e produto de um projeto de formação pautado em acumulação passiva de saberes e fazeres exteriores, pouco assimilados pelos estudantes. 
Deslocando a análise, agora, para a utilização da estratégia de coleta dos dados vale questionar sua aplicabilidade reconsiderando, preliminarmente, o uso da expressão "incidente crítico" em nosso meio. A intensidade de situações marcadas por problemas, limites, parece indicar uma apropriação de sentido distorcida, pouco relacionada a expressões de êxito, criação, crescimento, conforme possibilidades referidas no instrumento de coleta de dados reforçadas pela pesquisadora no momento do esclarecimento que antecedeu as respostas discentes.

Entretanto, cabe relativizar essa possibilidade na medida que quatro estudantes registraram situações que evoluíram bem, tanto na perspectiva assistencial quanto na eduacional, possibilitando crescimento, êxito e desgaste relativo às situações, disseram respeito: ao uso do brinquedo terapêutico; à realização de um parto; a participação num atendimento de emergência; a orientação sobre amamentação.

...manhã, disciplina de Pediatria do $3^{\circ}$ ano de graduação, no isolamento da enfermaria e estávamos eu, uma colega, a supervisora, a criança e a mãe. Banho numa criança de 3 anos... queimadura de $3^{\circ}$ grau, extensa, demos primeiro banho na boneca, a criança observou e logo após explicamos que ela também precisaria tomar banho na banheira... eu fiz levantamento bibliográfico... brinquedos terapêuticos. Demos o banho na boneca a criança prestou atenção, pudemos dar banho na criança que compreendeu através do brinquedo, que seria necessário ...como agir para amenizar o sofrimento da criança durante o banho... o brinquedo me ajudou muito durante a explicação... (24)

"Estágio de Obstetrícia, $3^{\circ}$ ano, segundo semestre, pela manhã, no pré-parto, a docente eu e mais três colegas de turma. Tudo corria bem... segundo a residente o parto seria para depois do almoço... quando a docente pediu para eu tocar... a cabeça já estava coroada. Foi uma correria... nos paramentamos no corredor mesmo... nasceu perfeito e 
eu fui a primeira a carregá-lo... Quando me dei conta a situação estava ali na minha cara, era enfrentar e pronto. E apesar a correria inicial, a docente conduziu com admirável competência técnica... isto me incentivou a trabalhar a hipótese de seguir obstetrícia."(6)

“...manhã e tarde, profissionais: médicos, residentes, enfermeiros, auxiliares de enfermagem, paciente, familiares, Disciplina Administração, $4^{0}$ ano, na sala de Politrauma do PS. Uma segunda-feira, na sala com todas as condições... cada equipamento testado... material reposto... ...Sala de Politrauma... uma jovem de 22 anos, estado grave... começou o atendimento seguindo os padrões do ATLS, com toda equipe integrada e treinada. A jovem tinha fratura de mandíbula e maxilar além de muito sangramento... intubação... acesso venoso... choque... bolsas de sangue... ringer aquecido... tomografia... vários procedimentos médicos que a equipe de enfermagem tem grande atuação... todas especialidades foram chamadas... Cheguei me paramentei como todos os outros da equipe, médicos, enfermeiros, auxiliares... Eu fiquei junto aspirando e manuseando algumas pinças... ajudei a fazer outras imobilizações... fiz $o$ exame físico neurológico junto com o residente... E pensei, e se fosse comigo? Quando o pai dela chegou... o que será que passou na cabeça e no coração desse senhor? ..."(28)

“...durante a visita... mãe, seu bebe, seu marido... nascido há 1 dia e ela ainda não tinha conseguido amamentar. Sentia culpada, frustrada, incapaz. Chegou a nos verbalizar... choravam muito, mãe e bebê e seu marido... muito apreensivo. Naqueles instantes, sinceramente, não lembrei de nada dos livros ou da teoria... porque foi situação totalmente inesperada ...tinha certa urgência de resolução. Toda confiança da paciente e de seu marido estava depositada em nós. Senti grande responsabilidade. Pedi a paciente que ficasse tranqüila pois iríamos ajudá-la a amamentar e também pedi a Deus que nos ajudasse naquele momento. Assim colocamos o bebê para mamar e nada... nada... nada aí ele começou a chorar novamente, e a mãe junto. Acalmamos novamente 
mãe e bebê e por fim, o bebê começou a mamar... Pedi a Deus que me desse tranqüilidade... a enfermeira também manteve-se serena durante todo o tempo."(17)

Outra perspectiva analítica ainda relativa à utilização do Incidente Crítico diz respeito ao próprio conceito de prática/ação/expressão clínica. Talvez o descompasso entre a expectativa de identificar construções de julgamento crítico e de pensamento clínico nas situações relatadas e a realidade dos esquemas de pensamento caracterizados, tendo por base conexões associativas simples e focais; com poucas evidências clínicas, decorra da fragilidade do conceito e do exercício do raciocínio clínico entre os graduandos. Nesse sentido, uma experimentação teórica inconsistente teria como resultado uma organização do pensamento / ação clínica limitada, justificando sua fragilidade nos depoimentos discentes.

Para especialistas como May et al. ${ }^{(34)}$ citando Watson; Glaser (1980), pensar criticamente envolve "conhecimentos e atitudes incluindo a investigação sobre um problema identificado, a aceitação de evidências para assegurar a veracidade e o conhecimento da natureza e valor das inferências, abstrações e generalizações nos quais os tipos de evidências são mensurados, considerando a precisão e relevância para uma solução lógica”.

Nessa perspectiva, existe uma relação lógica entre possuir um pensamento crítico e exercer a competência clínica, agregando: a habilidade de tomar decisões, de aproximar conhecimento e experiência clínica, tendo por base um arcabouço cognitivo, psicomotor e afetivo.

Portanto, investir no processamento do raciocínio clínico ainda representa um desafio de formação a ser viabilizado por dispositivos de integração e de mobilização de aquisições cognitivas pouco evidenciadas na cultura da Graduação vigente. 
Assim, as construções ideativas registradas estariam sinalizando a perpetuação de uma abordagem pedagógica que ainda considera o aprendiz como um acumulador passivo de saberes e fazeres desconexos e esvaziados de um sentido para além da esfera operacional.

Continuando a análise dos resultados, cabe ressaltar que, para os estudantes do $2^{\circ}$ ano, além das questões centradas na superação de limites operacionais para o desempenho a tempo e a gosto, tanto de docentes quanto de profissionais assistenciais, houve referências de dificuldades para além do "dar conta" acrescendo a essa meta um caráter de articulação ao conjunto, o fazer comum, o atuar junto ao grupo, apesar das dificuldades perfeccionistas.

Os registros que marcam esta etapa do desenvolvimento discente são:

"Na UTI... eu iria dar meu primeiro banho no leito... um odor horrível... o paciente tinha evacuado antes de iniciar o banho e a professora orientou para manipular o mínimo pois ela era cardíaca... dividimos as tarefas e eu fiquei com o banho... entrou o residente, docente e falou - Nossa porque esse bando de gente para dar um banho! ... foi horrível naquele momento eu estava passando por cima de muitas coisas.." (11)

“...paciente acidendou-se num mergulho, estava tetraplégico... nos preocupamos também com os cuidados no domicílio... encontramos dificuldade em fazer treinamento... a rotina da enfermaria não permitia familiares durante os procedimentos... pedimos avaliação da fisioterapia... queriam fazer os exercícios no horário de banho; equipe médica indiferente a evolução negativa das escaras..." (18)

"primeiro dia estágio... a responsabilidade pelo cuidado se iniciam no dia seguinte, após ter estudado. Fomos, examinamos, conversamos, a nossa paciente tinha tido um filho há 1 semana, mas estava na gastro com NPP... A paciente pediu que a ajudasse sair da 
cama, seguramos a NPP, a toalha, e fomos ler o prontuário... De repente... chegamos no quarto ela molhada, sem acesso central, médico examinando... as acusações... nós assustadíssimas chamamos a professora..." (15)

Houve também situações conflitantes na medida em que a apreciação do doente passou a ser reconhecida como atributo avaliativo, não apenas reconhecendo seu esforço, porém, primordialmente, expressando gratidão pela disponibilidade dele, estudante, em relação a um outro profissional referido como "mau cuidador".

“...que faziam os cuidados com pressa, sem dar atenção... limpavam o curativo com escovinha. Fiquei calma e aliviada em saber que eu proporcionava um alívio a ele... saber que consegui prestar assistência ao paciente que confiasse em mim e ouvir dele "muito obrigada" com um sorriso no rosto..."(7)

Esses depoimentos nos remete às condições da aprendizagem dos conteúdos procedimentais enquanto atividades que supõem um desafio ajustado às possibilidades reais do aprendiz, disposto segundo gradientes: do motor ao cognitivo, das ações simples e limitadas às complexas e diversificadas; das reiterativas àquelas com organização em aberto, possibilitando adequação ao nível de desenvolvimento de cada aluno. ${ }^{(19)}$

Os processos de realizações das ações procedimentais pressupõem, ainda, práticas guiadas e ajuda, exercitações suficientes, progressivas e ordenadas no sentido da melhor resposta possível para cada um. Agregam uma discussão reflexiva, uma consciência de ação, incluindo uma tomada de decisão acerca da melhor maneira de realização, das condições adequadas de uso além das 
possibilidades de aprimoramento, tendo o contexto de prática como princípio de realidade.

Desconsiderar essa complexidade, que atrela 0 desempenho à concepção e à consciência da ação, valorizando a destreza para a ação e para a inserção nos tempos e movimentos já desenvolvidos pelos professores significaria um objetivo de ensino desfocado, dificultando o processo de saber-fazer, sua transferência para a prática, além de poder atuar como elemento inibidor da potencialidade discente.

Muitos referiram um sentimento de impotência, sua frustração de "não dar conta", retratando uma postura dependente de acenos de valorização. Nesse processo interativo emerge um investimento complementar entre um ser estudante percebido como frágil e dependente e um outro sempre mais potente. Esse outro vem representado pelo docente "protetor" ou "controlador", pelo médico, referência maior de poder, inclusive deturpado, e pelo doente que funcionaria como suporte, como amortecedor das tensões inerentes à iniciação.

Merece destaque a sintonia que estudantes expressaram às considerações dos pacientes vinculando-os à sua atuação benevolente, "quase santa".

“...assistência a um senhor que tinha sofrido grave acidente de caminhão... fomos cuidar dos curativos e no final ele disse que éramos "anjos" e os auxiliares "urubus"... que faziam os cuidados com pressa, sem dar atenção... limpavam o curativo com escovinha..." (7) 
Esse evento seria mais um sinalizador de um padrão de aprendizagem ainda vinculado ao senso comum, mais reativo às viabilizações simbólico-afetivas que aos constructos teóricos.

Também em estudo referente a avaliação da competência clínica na graduação em Enfermagem, com o objetivo de apreender representações do pensamento crítico e do julgamento clínico, os resultados demonstram as mobilizações afetivas enquanto substrato do aprender a pensar e a agir sensivelmente. $^{(48)}$

No $3^{\circ}$ ano, o foco dos incidentes críticos continua sendo o procedimental acrescido agora de especificidades. Novos hábitos de pensamento e ação resultantes da integração de novos conjuntos disciplinares não ficaram evidentes.

É possível interpretar que a estrutura curricular agregando disciplinas clínicas, mantendo as respectivas lógicas internas não estaria promovendo uma organização somativa, fragilizando a integração de conceitos e métodos de abordagem clínica.

Mais uma vez, as experiências críticas retrataram uma intenção de formação que agregaria práticas próprias de especialidades (Enfermeira Pediátrica, em Centro Cirúrgico e Doenças Transmissíveis) às práticas prévias, sem a explicitação da contigüidade. A ampliação dos esquemas de pensamento e dos projetos de ação para além do desempenho específico em si se fizeram pouco presentes. É possível considerar que as aquisições disciplinares anteriores foram consideradas pouco transponíveis para as novas situações apresentadas como inéditas. A linguagem específica de cada disciplina também foi pouco utilizada. 
"O caso deste paciente me incentivou a estudar... chegava em casa e estudava... tinha interesse em aprender, conversar com os residentes... por mais que todos me falassem que ele era terminal..." (19)

“...porque eu não gostava de aspirar... tinha medo de ficar sem respirar naquele momento, ficar sem oxigênio..."(16)

"Num primeiro momento achei que eu não era "capaz" de cuidar... me sentia impotente. Tinha medo de demonstrar meus sentimentos para a mãe dela”.(3)

“...não queria me envolver demais com a situação e tinha medo da reação do professor... quando ele parou a gente chamou os residentes que constataram o óbito, eu me tranquei no banheiro e fiquei chorando muito, fiquei com medo de alguém ver a minha reação".(19)

Por outro lado, os incidentes críticos rememorizados pelos alunos do $4^{\circ}$ ano passou a ter um foco atitudinal. Ainda persiste as construções de sentidos mobilizadas por novas ações vinculadas, agora, ao cuidado do doente psiquiátrico que, pela peculiaridade de expressão, mobilizaria novos investimentos relacionais.

Entretanto, no último ano, o desafio marcante disse respeito às predisposições para atuar no conjunto e no contexto profissional, buscando adequar as próprias condutas ao ritmo e às regras de comportamento pactuadas.

A análise dos conteúdos registrados possibilita interpretações que trazem à cena o esforço dos estudantes em superar a relação dual (estudante-doente), buscando ampliar o foco e o sentido da prática assistencial. Houve declarações de intenções e de princípios, expressões de questionamentos relativos à interação profissional-doentes, incluindo as dificuldades de compor parcerias no contexto da equipe multiprofissional. O descompasso nos investimentos assistenciais face à 
impossibilidade de cura, o abandono dos doentes com prognóstico fechado, foram aspectos da dinâmica de atendimento que mereceram questionamentos.

Critérios morais fizeram parte da tomada de posição frente à condutas consideradas inaceitáveis imposições de tratamento, subestimação da capacidade do doente para opinar sobre o próprio tratamento, desinformação induzida jogos de manipulação, tentando imputar responsabilidade por ações consideradas como não pactuadas, foram percebidos e refutados por estudantes. A postura docente referida como tendenciosa no julgamento de situações críticas foi foco de reação, evidenciando amadurecimento e ampliação da consciência acerca do complexo interjogo de relações e poderes instituídos e instituintes.

As expressões reveladas pelos discentes neste momento do desenvolvimento estão registradas a seguir.

“...porque eu não gostaria de ter passado o que ela passou sem saber a verdade... acham que dar atendimento gratuito eles não têm direitos... o que o médico faz ele sabe e o paciente não precisa ser comunicado... uma sensação de prepotência... não precisa explicar pois são humildes não vão entender. Não existe isso, a pessoa tem o direito de saber..."(1)

“...complicado trabalhar em equipe, que era o que o paciente precisava no momento... cirurgia plástica x comissão de curativo... agravado quando neuro achou que não poderia mais investir, com tratamento caro... a enfermagem, a nutrição e a fono discordavam."(2)

“...porque não precisava ter tomado uma bronca de uma pessoa que não sabia e não procurou saber o que havia acontecido. E também porque poderia ter causado um grande mal ao paciente." (13) 
"Era o $1^{0}$ dia de estágio... chegamos no CAPS, ficamos um pouco perdidas... Fiquei pasma a Sta. $M$ veio em direção a mim e me abraçou. Como? pessoa que eu não conhecia e a paciente tão amigável... Houve uma dinâmica, eu fiquei observando, no final a Sra. M desabafa em choro a morte do seu irmão há 7 anos. Naquele momento nenhuma psicóloga tenta acalmar ou interagir com $M$ que acabou ficando agressiva. Todos saíram da sala e M ficou chorando a morte do irmão. Eu não sabia como abordar..." (20)

“...enfermaria de ginecologia, paciente com diagnóstico médico de Ca de mama, já tinha feito QT para posteriormente fazer mastectomia total. ...ela não queria fazer a mastectomia total... os médicos foram pragmáticos em dizer ou a paciente fazia a cirurgia ou desocupava o leito mesmo sem realizar todos os exames... pedi que tivessem paciência e esperassem a decisão da paciente... senti muita angústia pois não queria que a paciente fosse embora sem realizar a mastectomia. Após... feliz por ter alcançado o meu objetivo". (23)

“...por perceber que aquele profissional não considerou aquele paciente como ser humano... mais um que foi a óbito". (26)

"Pois tenho certeza de que não falei errado... a professora me tratava muito mal e acredito que fui prejudicada na nota por isso". (29)

Sintetizando, é possível considerar que os incidentes críticos analisados foram capazes de retratar situações de aprendizagem marcantes sob a ótica dos estudantes, estabelecendo relações significativas mais com práticas do que com conceitos, evidenciando, ainda, as mobilizações decorrentes das experiências vivenciadas, compondo os resultados analisados a seguir. 


\subsubsection{As reações ao incidente crítico}

Nesse âmbito analítico foram sintetizados os conteúdos relativos: aos motivos, às justificativas que fizeram com que o incidente fosse considerado crítico; a reação discente à situação; os sentimentos vivenciados no decorrer da situação, culminando na expressão do custo e do ganho com a experiência enquanto possibilidades de (in)satisfação, compondo uma complementariedade relevante de informações acerca da aprendizagem clínica.

Quadro 11 - Justificativas para a identificação do incidente crítico. São Paulo, 2004

\begin{tabular}{|c|c|c|}
\hline $2^{\circ}$ ano & $3^{\circ}$ ano & $4^{\circ}$ ano \\
\hline Motivos & Motivos & Motivos \\
\hline Externos & Externos & Externos \\
\hline $\begin{array}{l}\text { - falta de material } \\
\text { - condição do doente } \\
\text { (gravidade) }\end{array}$ & $\begin{array}{l}\text { - condição de um "novo" doente } \\
\text { (criança, gestante, o paciente } \\
\text { cirúrgico, o doente com DT) }\end{array}$ & $\begin{array}{l}\text { - fragilidade do trabalho em } \\
\text { equipe } \\
\text { - dificuldade de pactuar } \\
\text { comportamento }\end{array}$ \\
\hline $\begin{array}{l}\text { - postura do docente } \\
\text { (cobrança) }\end{array}$ & - postura docente (tendenciosa) & Internos \\
\hline $\begin{array}{l}\text { - postura do médico } \\
\text { (desconsideração) }\end{array}$ & $\begin{array}{l}\text { - postura médica (prepotência, } \\
\text { manipulação) }\end{array}$ & $\begin{array}{l}\text { - capacidade de atuação em } \\
\text { procedimentos complexos }\end{array}$ \\
\hline Internos & Internos & - dificuldades em: \\
\hline $\begin{array}{l}\text { - limitação } \\
\text { - medo }\end{array}$ & $\begin{array}{l}\text { - dificuldade de desempenho } \\
\text { técnico (novos procedimentos) }\end{array}$ & $\begin{array}{l}\text { - garantir seguimento } \\
\text { - conciliar administração/cuidar }\end{array}$ \\
\hline - Inabilidade & $\begin{array}{l}\text { - o convívio com a dor, com a } \\
\text { morte, com o sofrimento }\end{array}$ & $\begin{array}{l}\text { - exercer novas ações } \\
\text { (abordagem do doente } \\
\text { psiquiátrico) }\end{array}$ \\
\hline $\begin{array}{l}\text { - falta de embasamento } \\
\text { - } \begin{array}{l}\text { impotência } \\
\text { manipulação) }\end{array} \text { (morte, }\end{array}$ & $\begin{array}{l}\text { Relacionais } \\
\text { - abordagem de "novos" } \\
\text { pacientes / família }\end{array}$ & $\begin{array}{l}\text {-assimilar "dever não cumprido" } \\
\text { Relacionais }\end{array}$ \\
\hline Relacionais & $\begin{array}{l}\text { - a percepção da impaciência do } \\
\text { doente }\end{array}$ & $\begin{array}{l}\text { - convívio com práticas } \\
\text { desrespeitosas }\end{array}$ \\
\hline - manipulação da equipe & $\begin{array}{l}\text { - a reação à situação de } \\
\text { aprendizagem impostas }\end{array}$ & - condutas impositivas (docente) \\
\hline Percepção da Prática & $\begin{array}{l}\text { Percepção da conseqüência da } \\
\text { ação }\end{array}$ & $\begin{array}{l}\text { - dificuldade em promover a } \\
\text { motivação do grupo }\end{array}$ \\
\hline $\begin{array}{l}\text { - desarticulada } \\
\text { - diferente (da teoria) }\end{array}$ & $\begin{array}{l}\text { - erro } \\
\text { - julgamento }\end{array}$ & $\begin{array}{l}\text { - exposição junto à equipe } \\
\text { Percepção da prática }\end{array}$ \\
\hline $\begin{array}{l}\text { - percepção de atuações } \\
\text { questionáveis }\end{array}$ & - manipulação de informações & $\begin{array}{l}\text { - desconsideração de questões } \\
\text { éticas } \\
\text { - investimentos muito } \\
\text { conflitantes } \\
\text { - implicações do erro } \\
\text { - valor dos registros }\end{array}$ \\
\hline
\end{tabular}


Os determinantes que levaram às situações a serem considerações críticas são múltiplos, são complexos, prenunciando a existência de uma rede interpretativa significante. Os estudantes, independente do momento marcante ter ocorrido no $2^{\circ}$, no $3^{\circ}$ ou no $4^{\circ}$ ano, conseguiram recompor elos de ligação que justificam a priorização das experiências relevantes.

Essa relevância decorreria de um julgamento apurado acerca dos marcadores de criticidade, envolvendo: dificuldades concretas (falta de material); percepção de descompasso entre o próprio desempenho e a condição do doente selecionado para a prática; uma noção de exposição, tanto às determinações docentes quanto ao domínio médico; consciência do limite exacerbado talvez pelos conflitos e desgastes presentes nas situações de aprendizagem; uma dificuldade de aceitação de expressões reais da dinâmica assistencial, incluindo posturas, condutas, declarações de intenções uma inabilidade de inserção no conjunto intra e interprofissional ainda pouco acessível às suas condições, aos seus sentimentos e preferências; e uma noção ampliada quanto às repercussões da ação, incluindo possibilidades de iatrogenia, conforme alertou os depoimentos a seguir.

"No Hospital Dia, disciplina de Psiquiatria, $1^{\circ}$ semestre do $4^{\circ}$ ano, na sala de medicação, preparando juntamente com uma auxiliar de enfermagem e uma colega... O local é tumultuado, todas entram e saem, um "falatório intenso" e... prescrições médicas com letras péssimas ...já sabia preparar medicação, havia estudado as medicações prescritas... por apenas uma letra do nome do medicamento eu troquei a medicação. Fui administrá-la, por sorte o paciente percebeu... pois nunca tomara daquela cor”. (13)

Nessa discussão, os registros trariam um suporte reflexivo ampliado como precursor de disposições de reação basicamente intuitivas, tímidas, com certo grau 
de descontrole afetivo no enfrentamento das dificuldades, conforme alerta o quadro referido a seguir.

Quadro 12 - Justificativas para a identificação do incidente crítico. São Paulo, 2004

\begin{tabular}{lll}
\hline \multicolumn{1}{c}{$\mathbf{2}^{\circ}$ ano } & \multicolumn{1}{c}{$\mathbf{3}^{\circ}$ ano } & \multicolumn{1}{c}{$\mathbf{4}^{\circ}$ ano } \\
\hline - choro, desculpas, fuga & - estudar mais & - integrar-se \\
- perseverança, paciência, & - experimentar & - buscar explicações \\
- argilização, iniciativas & - conquistar confiança & - investir no convencimento do \\
busca de suporte (docente) & - melhorar comunicação & - doente \\
- tentativa de ampliar & - utilizar recursos alternativos & expressão do doente \\
compreensão & (policial) & - dar continuidade ao cuidado \\
- investimento no melhor & - ocultar envolvimento (esconder de \\
cuidado possível & - investir no acolhimento \\
- investimento na avaliação do no acolhimento & - defender-se (sem êxito) & \\
doente como reforço para a & & \\
própria ação &
\end{tabular}

É possível identificar um amadurecimento nas estratégias de convívio/enfrentamento das situações críticas. Naquelas ocorridas no $2^{\circ}$ ano, 0 esforço parece ter gradativamente evoluído da manifestação do sofrimento, para um auto-controle, em atitude de compreender e atuar com mais segurança, uma motivação para um cuidar melhor, tendo na resposta do doente o ponto de referência.

“...numa manhã, eu e uma colega de turma, eu cursava Fundamentos de Enfermagem na enfermaria de Ortopedia, no $2^{\circ}$ ano. As professoras sortearam um paciente... eu 
afônica, o paciente com grande dificuldade de audição, a colega sem iniciativa... o paciente com descolamento da prótese de fêmur. Fomos dar banho... ele gritava de dor.. demorei muito tempo para realizar... não sabia direito o que fazer, e quem acabou sofrendo foi o paciente." (21)

As situações vivenciadas no $3^{\circ}$ ano trazem como investimentos relembrados um direcionamento para o aprender a aprender, incluindo a aprendizagem de estratégias interativas, de acolhimento. Houve tentativas de disfarçar o envolvimento afetivo, tendo por justificativa o receio de uma avaliação de inadequação. Esse convívio conflitante com julgamentos também gerou iniciativas de auto defesa contra posturas tendenciosas por parte de profissionais e docente envolvidos em situações críticas (desencontro de informações com possibilidade de erro).

“...tinha uma paciente com tétano... eu não pretendia cuidar dela no começo... o professor distribuiu os leitos e me deu justo esta paciente, fiquei nervosa, mas fui. Entrei no quarto com outra aluna, vi a paciente traqueostomizada... o professor disse para aspirar... eu não gostava, tinha medo". (16)

“...não queria me envolver demais com a situação e tinha medo da reação do professor... quando ele parou a gente chamou os residentes que constataram o óbito, eu me tranquei no banheiro e fiquei chorando muito, fiquei com medo de alguém ver a minha reação".(19)

“...alunos divididos em 2 turmas $\mathrm{Ml}$ e dermato, eu estava há 2 semanas com o mesmo paciente na dermato... fiz o HGT e verifiquei estava alto... Fui para a sala de medicação e vi que as 2 colegas estavam atrapalhadas... já havia passado a hora... Então disse para técnica de enfermagem e fui embora. O tempo passou e nada do medicamento... 
Quando descobrimos eles já estavam levando o medicamento para o paciente errado... a técnica logo falou que eu havia falado o número do leito errado. O caso foi exposto para a professora que ficou contra mim. Disse que era impossível a técnica ter errado..." (29)

Dentre as reações referidas como tendo ocorrido no $4^{\circ}$ ano 0 foco passou a ser interativo quer na perspectiva da atitude favorável, motivadora, quer no sentido do questionamento, explícito ou não, de posturas, de investimentos interprofissionais. Houve maior expressão de autonomia ainda que timidamente revisando a atuação conjunta. Identificamos, ainda relatos de tentativas para ampliar espaços de existência e de expressão dos doentes ainda que de caráter reiterativo, no sentido de esclarecer condutas como indicativo para aceitação da assistência imposta.

“...4ำ ano, disciplina Administração, período da manhã, Clínica Médica I, aproximadamente 30 leitos, enfermeira responsável de férias, funcionários não muito cordiais... paciente internado há 2 meses por Doença do Neurônio Motor por intoxicação por organofosforado, ....acompanhado pela família... consciente, com expectativa de cura e para equipe médica sem expectativa... Há mais de 1 mês em jejum muito ansioso para comer... embora eu conversasse com os médicos eles não liberaram... curativo de escara por ser feito e conflito entre a equipe de como fazer".(8)

“...todos as disciplinas da graduação nos remeteram o olhar o paciente como um todo... independente da possibilidade de cura ou não... o conforto e a dignidade tornam-se imprescindíveis..." (8) 
Haveria nesse elenco de reações um desenvolvimento comportamental, incluindo uma atitude favorável, apesar dos confrontos, uma funcionalidade mais desenvolta, um conflito cognitivo precursor de posturas mais conscientes. Entretanto, essas construções evidenciaram poucas conclusões, generalizadas, resumo de idéias importantes, situações precursoras de encadeamentos teóricos-operacionais, projetos de ação alternativos, reiterando uma dificuldade conceitual já referida anteriormente.

A consciência dessa mobilização gerou depoimentos que atestam mobilizações afetivas vivenciadas no decorrer das experiências clínicas, compondo um elenco de sensações comuns, independente do ano de ocorrência dos eventos críticos.

Preliminarmente, as sensações referidas como marcantes decorreram: da noção do próprio limite (medo, insegurança, decepção); da percepção da diferença de status/papel (humilhação pela reação do médico); do desamparo na medida em que os colegas não chegaram a compor parcerias, vínculos; do desespero e raiva frente ao sofrimento e à manipulação de doentes; de mágoa pelo julgamento e de medo das repercussões da ação, tanto no doente quanto na própria avaliação.

Agregam estas vivências marcadas pelas falas a seguir:

"Um senhor de 60 anos em P.C.R e foi a óbito. A auxiliar tirou o abocath do paciente e não comprimiu o local, logo depois colocou uma etiqueta do hospital com o nome, RG no peito do paciente". (26)

“...primeiro curativo... não precisava ser repreendida como aconteceu na frente dos pacientes e que nos provoca maior insegurança”. (27) 
"Pois tenho certeza de que não falei errado... a professora me tratava muito mal e acredito que fui prejudicada na nota por isso". (29)

“...eu me senti assustada... revoltada e apavorada pela insensibilidade do médico e a falta de respeito com a paciente”.(1)

“...todos os alunos tinham escolhido os pacientes, menos eu porque a professora "me deu"... a mais difícil tanto esteticamente como em relação à família". (3)

“...eu ainda não tinha bagagem significativa para contornar à situação”. (4)

“...enfermeira pediu para acalmar um paciente na sala de procedimentos... o funcionário ia colher sangue... eu segurava o tubo... o funcionário fechou a janela pois os demais caçoavam do paciente... docente ficou furiosa, ela dizia que eu estava fazendo o procedimento... que as alunas eram ingênuas em me defender..."(9)

"Minha professora pediu para suas alunas do $2^{\circ}$ ano passar plantão para mim, do $4^{\circ}$ ano, e tinham feito um maravilhoso trabalho... comecei a chorar... achava não ser capaz de continuar aquele trabalho". (22)

Vale salientar que relatos similares foram identificados em outros estudos evidenciando um clima de aprendizado marcado por tensão mesmo frente a situações aparentemente pouco complexas. Mais uma vez sensações imobilizadoras parecem mediar as práticas de formação, fazendo-nos reconsiderar a adequação da construção das experiências de ensino aprendizagem, levando-nos a questionar o planejamento das atividades das situações; a atenção dada as diversidades, o reconhecimento de avaliações apropriadas as características pessoais ${ }^{(19)}$, enquanto investimentos passíveis de relativizar uma aprendizagem por si mesma mobilizadora 
de medos (da morte, do erro, do sofrimento), fantasias (persecutórias), conflitos no convívio.

O estudo realizado por Angelo $^{(7)}$ sobre o significado das experiências iniciais de aprendizagem prática para alunas de enfermagem, intitulada vivendo uma prova de fogo, revelou ocorrências marcadas pelo sofrimento e imobilização dos alunos ao se depararem com a realidade no campo clínico.

A contribuição trazida pelo trabalho de Matheus $^{(8)}$ quando nominou um dos fenômenos "vivendo uma transição reveladora e complexa", onde a enfermeira recém-formada é caracterizada por apresentar nesta fase uma experiência marcada, neste novo papel, pela percepção da desarmonia entre si e o serviço, ela percebe a discrepância entre a formação e o trabalho. Há a necessidade inevitável e imediata de adaptação à nova condição, percebendo ainda que tardiamente a força que tem o contexto, embora a graduação não tenha explicitado estas características, mantendo o ensino na perspectiva do ideal sem trabalhar adequadamente o que seria a realidade, trazendo à recém-formada as dificuldades para inserção no mundo do trabalho. ${ }^{(8)}$

Com isto, deriva também deste estudo a categoria "vivendo um período de latência", expressa pelo desvendamento gradativo dos processos contidos no contexto, mostrando então a realidade diferenciada e complexa. Viver este período gera sentimentos e atitudes contraditórias, ora de aproximação, ora de rejeição, ora de realização, ora de insatisfação, marcando o custo e o sentido dessa adequação, inclusive no deslocamento do cuidar ideal para a condição do cuidar possível, conforme descreve a autora ${ }^{(8)}$ 
É possível questionar ainda, o nível de exigência docente e o quanto ele vem acompanhado de apoio e suportes de todo tipo, "dos instrumentos tanto intelectuais como emocionais que possibilitem que os alunos superem essas exigências e desafios, tornando-os desafios abordáveis".(24)

Pesquisadoras na área da Educação em Enfermagem têm discutido amplamente sobre o descompasso entre a formação acadêmica e a prática vivenciada no mundo do trabalho. Estudos das autoras Ide, Chaves ${ }^{(69)}$; Ângelo ${ }^{(70)}$; Bagnato $^{(72)}$; Geib ${ }^{(73)}$; Ern, Backes ${ }^{(74)}$, marcam esta análise. Outras autoras que estudam a inserção do enfermeiro no mundo do trabalho como Matheus ${ }^{(8)}$, Martins $^{(55)}$, De Domenico ${ }^{(67)}$, Püschel ${ }^{(71)}$, destacam também a fragilidade no emprego de metodologias de ensino dissonantes às necessidades de desenvolvimento do aluno na vivência de aprendizado de competências ampliadas, com múltiplas dimensões, permitindo assim condições de uma vivência mais apropriada, onde poderia instrumentalizá-lo a buscar as referências da profissão com menor custo pessoal.

Com isto, repensar os objetivos educacionais, colocando intencionalidade nos resultados pode proporcionar um processo ensino-aprendizagem tendo como sustentação metodológica os princípios construtivistas. Propor então um ensino por competências aliado a esses princípios, vislumbra-se grande interrelação por contemplar desenvolvimento de capacidades cognitivas, motoras, de equilíbrio e autonomia (afetivas), de relação interpessoal e de inserção e atuação profissional ${ }^{(19)}$.

Com essas capacidades o indivíduo poderá promover o desenvolvimento pessoal necessário ao favorecimento de uma atuação profissional, que atenda a demanda do trabalho ampliado na equipe e com possibilidades de ação autônoma e criativa. 
Portanto a concepção construtivista propõe um conjunto articulado de princípios que proporcionam diagnosticar, julgar e tomar decisões fundamentais sobre o ensino ${ }^{(24)}$.

$\mathrm{Na}$ medida em que as iniciativas foram contornando os dilemas, gradativamente o sentimento de impotência parece ter-se relativizado, o desgaste foi sendo referido como menor. Sensações prazerosas foram relembradas.

"Durante... fiquei nervosa, tremi muito. Após... eu me senti capaz e satisfeita por ter conseguido romper essa barreira". (16)

"eu senti como se estivesse com uma grande amiga, em um momento difícil. Após, recompensada, feliz e com sensação de paz...” (14)

“... senti-me tensa, mas procurei passar tranqüilidade. Após... aliviada quando o bebê começou a mamar e então vi o sorriso da mãe e do pai. O pai levantou da cadeira e foi abraçar a mãe. Fiquei muito feliz". (17)

“...muito feliz pois percebi que ela ficou mais calma depois que eu e a docente conversamos e ouvimos a paciente". (25)

“...muita insegurança, mas após ter conseguido uma satisfação e felicidade por ter conseguido e principalmente por ver o reconhecimento do paciente pelo meu esforço".(27)

"Eu aprendi que tudo precisa ser anotado para se conseguir provar... que encontrarei pessoas que botarão à prova minha competência..." (29) 
A satisfação foi associada ao reconhecimento das iniciativas ao aprimoramento técnico e relacional, à ampliação do conhecimento, ao êxito. Mais uma vez, a valorização externa, advindo do doente foi uma fonte significante de prazer. A ampliação da consciência crítica, reconhecendo jogos de manipulação e estratégias de defesa (valor da anotação) foram relembradas como ganhos. Persistiram depoimentos onde a vergonha (do médico) e o medo de represarias se manifestaram como reação à humilhação e a desconsideração pela atuação.

Sintetizando, é possível considerar como tendo sido válida a utilização do incidente crítico como elemento avaliador da dinâmica de desenvolvimento da competência clínica entre os estudantes pesquisados. Seus elementos constitutivos foram se desenvolvendo por meio de experiências vivenciadas no decorrer da graduação, adquirindo expressões em expansão, em uma dialética estabelecida entre as antigas e as novas aquisições de pensamento e de ação. Os sentimentos mobilizaram-se no sentido de uma vivência menos tensa, a satisfação decorreu da sensação de superação e de realização e reconhecimento. A aprendizagem parece ter sido significativa, evidenciando limites e possibilidades a merecerem reconsiderações. 


\section{CONSIDERAÇÕES}

FINAIS 


\section{CONSIDERAÇÕES FINAIS}

\subsection{Contribuição para uma reconsideração do processo ensino-aprendizagem}

Essa pesquisa se propôs a ampliar o conhecimento sobre um tema significativo, ou seja, o processo de desenvolvimento da competência clínica, incluindo expressões de concepções docentes e de experiências discentes intrínsecas a essa dinâmica.

O contato com os dados envolve exercícios analíticos, o relacionamento dos achados com outras idéias e ideários, com ênfase na perspectiva construtivista, a caracterização do projeto, o reconhecimento de intenções, o desvendamento de apreciações e de reações inerentes ao desenrolar das experiências de aprendizagem, incluindo as considerações críticas, compondo um conjunto de informações a serem analisadas numa dupla abordagem.

Preliminarmente, cabe evidenciar aspectos relevantes da organização curricular, cuja proposição permaneceu centrada em disciplinas, com modalidades organizativas que partem do genérico (Fundamentos de Enfermagem/Enfermagem Médico-Cirúrgica) para o mais específico/especializado (Enfermagem em Centro Cirúrgico, Enfermagem em Doenças Transmissíveis, Enfermagem Pediátrica, Enfermagem Ginecológica, Obstétrica e Neonatal, Enfermagem Psiquiátrica, Enfermagem Preventiva e Comunitária), mantendo lógicas internas aparentemente refratárias à organizações somáticas que teriam por similaridade investimentos na ampliação da competência clínica. 
Esse estilo de organizar conteúdos, com proposição por disciplinas, dificulta tanto a integração de conceitos e práticas voltadas à capacitação clínica quanto a sua transferência para novas situações de aprendizagem. Essas aquisições seriam sempre apresentadas e vivenciadas como "novas", reiterando uma relação discente com o saber anterior como sendo inexistente ou inadequada. Nesse sentido, a transposição didática pouco se aplica, dificultando a utilização pelo discente de suas aquisições para novas situações, novos contextos, buscando novas soluções para problemas complexos. Mais do que tudo, dificultaria o exercício de competências enquanto:

- "Mobilização de saberes declarativos (que descrevem o real), procedimentais (que prescrevem o caminho a ser seguido) e condicionais (que dizem em que momento deve se realizar determinada ação). Esse exercício é mais do que uma simples aplicação de saberes; ele contém uma parcela de raciocínio, antecipação, julgamento, criando, síntese e risco. O exercício da competência põe em andamento nossos habitus e, sobretudo, nossos esquemas de percepção, de pensamentos e de mobilização dos conteúdos e informações que memorizamos..., exigindo situações de formação mais criativas e mais complexas que as alternâncias entre aulas e exercícios".(15)

Os resultados também ressaltam uma direção da aprendizagem voltada à execução metódica de práticas em evolução, escolhidas pelos docentes, estimulando a inserção discente em programações pré-estabelecidas e reiterativas.

A seqüência do ensino aprendizagem teria uma intenção e uma preparação definidas pelos professores, incluindo meios materiais, informações e etapas pouco sensíveis à necessidade de criar condições que favoreçam a motivação, compreensão e aplicação de conhecimentos ativamente construídos. 
A ligação das atividades de ensino à vida real se faz por meio de práticas em campo que respondem timidamente à problematização da realidade, promovendo poucas iniciativas de integração consciente. As intervenções parecem ser privilegiadas segundo uma ordem externa, às vezes distante da realidade dos alunos, aparentemente desconsiderando interesses, questionamentos e experiências significativas para eles.

Como resultado complementar desse investimento, emergem sinalizações de uma aprendizagem com vínculos pouco substantivos entre os conhecimentos prévios e a potencialização do julgamento crítico e do raciocínio clínico, também pouco mobilizados no sentido da ampliação dos esquemas de pensamento e dos projetos de ação enquanto manifestações de construção, modificação, ampliação e diversificação das expressões de competência clínica que, nessa perspectiva, pouco evoluíram. A relevância dos conteúdos de aprendizagem decorreram mais da prática reiterativa do que da potencialidade formativa de novos investimentos teóricooperacionais.

Em síntese, é possível considerar que esses resultados reforçam o dever da mudança,

- "deslocando o ensino da linha de montagem para uma rede de relações que faça da construção de competências a verdadeira arma para enfrentar os problemas e superá-los. O saber articulado não pode ser relacionado a um modismo porque a revolução da tecnologia e das relações de trabalho certamente tem excluído, mais do que incluído profissionais. Considerando os fatos e querendo reconstruir uma expressão profissional demasiadamente dependente de normatizações 
e do controle de corpos e mentes, as bases construtivistas assumem destaque num enfoque renovado da Enfermagem".(6)

Entretanto, qualquer proposição pressupõe uma reflexão anterior sobre a consistência dos esquemas de pensamento e de ação desse grupo docente que, com maior ou menor tensão, expressa uma estabilidade de condutas educativas que corrobora a noção de um hábito, de uma "gramática geradora"(74) comum, apreendida pelas manifestações que vêm norteando o ensino das competências.

Nesse sentido, investimentos voltados à mobilização desses conceitos e práticas têm que enfrentar dinâmicas complexas que envolvem tomada de consciência, motivação, disponibilidade e intencionalidade para a transformação cabendo reproduzir as seguintes considerações:(15)

- "Por que assumimos o trabalho e os riscos, por mínimos que sejam, de qualquer tomada de consciência? Por jogo, narcisismo ou por exigência de lucidez? Às vezes. Mas, sobretudo, para controlar o habitus, discipliná-lo, reforçá-lo, transformá-lo, a fim de que ele seja menos impulsivo, menos angustiado, menos agressivo, mais imaginativo, mais audacioso, mais reflexivo, etc.",(15)

- "O desejo de mudança nasce da decepção, do descontentamento com aquilo que se faz. Acima de tudo, uma pessoa quer que sua prática, compreendida como a repetição de atos semelhantes em circunstâncias semelhantes, evolua. Quando a repetição persiste, apesar dos esforços e da tentativa de se controlar, de disciplinar, a pessoa chega à conclusão de que é conduzida por um esquema ou 
por vários esquemas de pensamento e de ação que estão fora do alcance de sua consciência e de sua vontade. Nesse momento, um trabalho sobre o habitus é pertinente, seja ele denominado forma de ser, hábito, rotina, automatismo, obrigação, caráter, personalidade ou mesmo de "reflexo"(15).

O enfrentamento desses desafios rumo à transformação, pressupõe portanto, a consciência da complexidade da missão que agrega obstáculos relativos: ao envolvimento do grupo no projeto de mudança; à peculiaridade do trabalho coletivo, incluindo os conflitos, zonas de sombras, não-ditos, dentre outras expressões interativas que ocultam desejos, jogos de poder; as especificidades de cada prática, as dificuldades, as tensões, as concepções, os desafios que cada um, que cada grupo docente atribui às possibilidades de resistência e aos espaços de transformação.

Essa ressalva foi inserida nessa análise para explicitar a compreensão de que iniciativas voltadas à proposição de referenciais tornar-se-iam ingênuas se desconsiderassem a complexidade implícita nos processos de mudança, exigindo competências ampliadas e específicas para uma atuação que, considerando os dilemas e jogos interacionais, seja capaz de mobilizar docentes para novos desafios, que pressupõem: ${ }^{(15)}$

- "Consenso no sentido de agregar direção, professores, discentes e profissionais assistenciais participantes da formação do projeto, aos conceitos, às práticas acordadas;

- Investimento nas competências requeridas como necessárias e suficientes para a clínica em Enfermagem, considerando a prática 
junto ao cliente, ao conjunto de clientes e a coordenação de processos de cuidar. Nessa construção, os saberes devem estar ligados às competências, em vez de serem considerados fins em si mesmos;

- Possibilidades de transposições didáticas, apropriação, elaboração e validação de projetos assistenciais como condição imprescindível ao desenvolvimento da autonomia;

- A inserção das dimensões transversais da formação de competências como aportes teóricos e de aprofundamento processual; superando o seu caráter introdutório, de fundamentação;

- Ter as condições da prática clínica como princípio de realidade incluindo a problematização do desempenho, os conflitos, os dilemas, os jogos instituídos, a sedução, a desordem, a ordem, o poder, a coerção, etc;

- Evidenciar a relação/utilização da pesquisa, dos preceitos éticojurídicos dos elementos que também balizam a tomada de decisão;

- Renunciar às prescrições ou receitas fechadas, possibilitando a compreensão das situações e a busca/proposição de projetos de ação com autoria;

- Agregar o envolvimento crítico e a interrogação ética enquanto "elementos de um julgamento profissional situado na encruzilhada entre a inteligência das situações e a preocupação com o outro".

Frente a essas premissas cabe finalizar a pesquisa propondo referenciais para o desenvolvimento da competência clínica; mais uma vez adequando à Enfermagem pressupostos construtivistas. 


\subsection{A influência da concepção construtivista na constituição das competências clínicas.}

Tendo por referência os dados do estudo e a potencialidade do quadro teórico pôde-se investir numa contribuição ao aprimoramento do processo de formação clínica, evidenciando os seguintes princípios norteadores dessa construção:

- "O melhor jeito de organizar o currículo é por projetos didáticos. Nessa proposta o docente abandona o papel de transmissor de conhecimento para se transformar num pesquisador, trabalhando com situações da vida real, estabelecendo objetivos, buscando evidências, tomando decisões".(19)

- "Numa perspectiva construtivista de processo ensino aprendizagem a prioridade é que o aluno aprenda e não que o professor ensine",(23)

- "A idéia de rede constitui imagem emergente para a representação do conhecimento... Nessa perspectiva, conhecer é como enredar, tecer significações, partilhar significados. Os significados por sua vez são construídos por meio de relações estabelecidas entre objetos, noções, conceitos. Um significado é como um feixe de relações". (75)

- Essa construção "desenvolve saberes, os quais, inicialmente são situados e contextualizados e, em seguida, vinculados às teorias acadêmicas e aos saberes profissionais acumulados. De modo paralelo, ele desenvolve capacidades de aprendizagem, auto-observação, autodiagnóstico e autotransformação. Na melhor das hipóteses, forma profissionais capazes de aprender e de mudar pó si 
próprios, sozinhos ou em grupos, em uma dinâmica de equipe ou da instituição,;(15)

- Esse "saber analisar pode ser nutrido por meio da iniciação à pesquisa, mas resulta, sobretudo, de um treinamento em análises de situações complexas"; $;(15)$

- Na constituição da competência clínica a teoria pode ser desenvolvida a partir da ação: "na primeira construção conceitual fornece uma grade de leitura do que ocorre ou ocorreu ao mesmo tempo em que a realidade enriquece e diferencia o modelo... O estudante descobre que não há situações complexas sem que haja uma teoria que ofereça algumas pistas de inteligibilidade e que nenhuma teoria complexa permite enfrentar, de forma infalível, uma situação complexa";(15)

- Desenvolver a competência clínica pressupõe, portanto, "construir tanto o problema quanto sua solução, refletir, observar os dados em todos os sentidos, dar-lhes consistência, esboçar hipóteses e analisálas detalhadamente por meio do pensamento"; ${ }^{(15)}$

- Para facilitar sua aprendizagem se deduz uma série de funções dos professores, tendo como ponto de partida o planejamento, considerando: "a flexibilidade para permitir sua adaptação às necessidades dos alunos; o reconhecimento dos conteúdos prévios dos estudantes; o investimento no encontro do sentido da atividade proposta; o estabelecimento de metas ao alcance dos alunos; a disponibilidade para a ajuda adequada, promovendo uma aprendizagem menos traumática; a promoção de sua atividade mental auto estruturante, possibilitando o controle pessoal sobre os próprios 
conteúdos e processos durante a aprendizagem; a promoção de canais de comunicação que incitem a parceria responsável; a potencialização progressiva da autonomia e uma avaliação conforme suas capacidades e esforços, incentivando uma auto avaliação das competências como meio de controle e regulação da própria atividade".(15)

Esse ideário tem condição necessária ao aprimoramento da dinâmica de formação em Enfermagem, ainda que não represente condição suficiente para o desenvolvimento das competências que se pretende investir.

Nesse processo interagem elementos relacionados à dinâmica intrapessoal dos envolvidos, condições objetivas de prática e que, como já referido, induzem atuações que não têm necessariamente o pensamento e a tomada de decisão clínica como referência.

Entretanto, essa relação é dinâmica e sensível, inclusive, ao exercício de sua competência maior, dotada de poder mobilizador advindo de uma inserção consciente, sustentada, responsável e ética no contexto da prática clínica em saúde. 
REFERÊNCIAS BIBLIOGRÁFICAS 


\section{REFERÊNCIAS BIBLIOGRÁFICAS}

1 - Machado, NJ. Sobre a idéia de competência. In: Perrenoud P, Thurler MG. As competências para ensinar no século XXI. São Paulo: Artmed; 2002. p. 137-55.

2 - Quintana P, Roschke MA, Ribeiro EC. Educación permanente, proceso de trabajo y calidad de servicio en salud. In: Haddad QJ., et al. Educación permanente de personal de salud. Washington: OPS, 1994.

3 - Deluiz, N. Qualificação, competências e certificação: visão do mundo do trabalho. In: Ministério da Saúde (BR). Secretaria de Gestão de Investimentos em Saúde. Projeto de Profissionalização dos Trabalhadores na Área de Enfermagem - PROFAE. Brasília (DF); 2001. p. 5-15.

4 - Seabra, TMR. A dimensão psicossocial do cuidar na enfermagem: a expressão representacional da práxis [dissertação]. São Paulo (SP): Escola de Enfermagem da USP; 1999.

5 - Kirchhof ALC. Os educandos e os educadores frente as novas relações de trabalho: precisamos de novos valores estéticos? Texto Contexto Enferm 1999; 8(1): 61-6.

6 - De Domenico, E. B. Referenciais de competências segundo níveis de formação superior em Enfermagem: a expressão do conjunto [Doutorado]. São Paulo (SP): Escola de Enfermagem da USP; 2003.

7 - Angelo, M. Vivendo uma prova de fogo: as experiências iniciais da aluna de enfermagem [tese]. São Paulo (SP): Escola de Enfermagem da USP; 1989. 
8 - Matheus MCC. A obstinação como mediadora entre a idealização e a concretude do cuidado instituído: a experiência da enfermeira recém-formada [tese]. São Paulo (SP): Escola de Enfermagem da USP; 2002.

9 - Moreira TA. Compreendendo a vivência do paciente ao ser cuidado por aluno de enfermagem [dissertação] São Paulo(SP): Escola de Enfermagem da USP; 1998.

10 - Ribeiro MRR. Vivência da incerteza: a prática ritualística de professores de enfermagem pediátrica [dissertação] São Paulo (SP): Escola de Enfermagem da USP; 1995.

11 - Vargens, O M C. Tentando descobrir um modo de fazer enfermagem sem ser enfermeiro \#: os conflitos do estudante na construção da imagem da profissão. Rio de Janeiro (RJ): Edição do autor; 1997.

12 - Ide CAC, De Domenico EBL. A proposta construtivista no ensino da enfermagem. In: Ide CAC, De Domenico EBL. Ensinando e aprendendo um novo estilo de cuidar. São Paulo: Atheneu; 2001. p. 109-18.

13 - Pedro RF, Ide CAC. SAE: o lado sombrio de sua prática [monografia]. São Paulo (SP): Escola de Enfermagem da USP; 1997.

14 - Perrenoud P. Construir as competências desde a escola. Porto Alegre: Artes Médicas Sul; 1999.

15 - Perrenoud P. A prática reflexiva no ofício de professor: profissionalização e razão pedagógica. Porto Alegre: Artmed; 2002. 
16 - Conselho Nacional de Educação. Resolução CNE/CES n. 3, de 7 de novembro de 2001. Institui Diretrizes Curriculares Nacionais do Curso de Graduação em Enfermagem.

17 - Siqueira HCH, Portella MR, Arejano CB. A produção do conhecimento: o construtivismo como estratégia metodológica. Texto Contexto Enferm 2000; 9(1):93-111.

18 - Carretero M. Construtivismo e educação. Porto Alegre: Artes Médicas; 1997.

19 - Zabala A. A prática educativa: como ensinar. Porto Alegre: Artes Médicas; 1998.

20 - Sole, I, Coll C. Os professores e a concepção construtivista. In: Coll C, Martín E, Mauri T, Miras M, Onrubia J, Sole I, Zabala A. O Construtivismo na sala de aula. 6 ed. São Paulo: Ática; 1999. p. 9-29.

21 - Barros C. O mercado e o tomateiro. Educação 1997; 23(200): 56-7.

22 - Miras M. Um ponto de partida para a aprendizagem de novos conteúdos: os conhecimentos prévios. In: Coll C, Martín E, Mauri T, Miras M, Onrubia J, Sole I, Zabala A. O construtivismo na sala de aula. 6 ed. São Paulo: Ática; 1999. p. $57-77$.

23 - Coll C, Juan IP, Sarabia B, Valls E. Os conteúdos na reforma: ensino e aprendizagem de conceitos, procedimentos e atitudes. Porto Alegre: Artes Médicas; 2000. 
24 - Onrubia J. Ensinar: criar zonas de desenvolvimento proximal e nelas intervir. In: Coll C, Martín E, Mauri T, Miras M, Onrubia J, Sole I, Zabala A. O construtivismo na sala de aula. 6 ed. São Paulo: Ática; 1999. p. 123-50.

25 - Libâneo JC. Didática. São Paulo: Cortez; 1994.

26 - Demo P. Educar pela pesquisa. 4 ed. Campinas: Autores Associados; 2000. (Coleção educação contemporânea).

27 - Perrenoud P. Dez novas competências para ensinar. Porto Alegre: Artes Médicas Sul; 2000.

28 - Mauri T. O que faz com que o aluno e a aluna aprendam os conteúdos escolares? In: Coll C, Martín E, Mauri T, Miras M, Onrubia J, Sole I, Zabala A. O construtivismo na sala de aula. 6 ed. São Paulo: Ática; 1999. p. 79-121.

29 - Barbier JM. Elaboração de projetos de ação planificação. Porto: Porto Editora; 1993.

30 - Stein E. Aspectos filosóficos e sócio-antropológicos do construtivismo póspiagetiano II. In: Grossi EP, Bordin J. Construtivismo pós-piagetiano: um novo paradigma sobre a aprendizagem. Petrópolis: Vozes; 1993. p. 35-42.

31 - Perrenoud P. Ensinar: agir na urgência, decidir na incerteza. Porto Alegre: Artes Médicas Sul; 2001.

32 - Perrenoud P. Pedagogia diferenciada: das intenções à ação. Porto Alegre: Artes Médicas Sul; 2000. 
33 - Loureiro MM, Vaz MRC. A busca de nossos modelos de ensino: condição essencial para a transformação do modelo assistencial de enfermagem. Texto Contexto Enferm 2000; 9(2): 226-37.

34 - May B, Edell V, Butell S, Doughty J, Lang Ford C. Critical thinking and clinical competencie: a study of their relationship in BSN seniors. Nurs Educ 1999; 38(3): 100-10.

35 - Bradshaw A. Special issue clinical competence [Editorial]. J Clin Nurs 2000; 9(3) $319-20$.

36 - Benner P, Tanner CA, Chesla CA. Expertise in pratice. Caring, clinical judgment an ethics. New York: Springer Publishing Company, 1995.

37 - Gil CG. Como elaborar projetos de pesquisa. 2 ${ }^{\underline{a}}$ ed. São Paulo: Atlas; 1989.

38 - Lüdke M, Meda A. Pesquisa em Educação: abordagens qualitativas. São Paulo: EPU; 1986. p. 38-43.

39 - Waldow VR, Lopes MJM, Meyer DE. Maneiras de cuidar, maneiras de ensinar. A enfermagem entre a escola e a prática profissional. Porto Alegre: Artes Médicas; 1995.

40 - Dela Coleta JA. A técnica dos incidentes críticos - aplicações e resultados. Arq Bras Psicol Apl 1974; 26(2): 35-58.

41 - Flanagan JC*. A técnica do incidente crítico. Arq Brás Psicol Apl 1973; 25(2): 99-141. *Traduzido do Psychological Bulletin, 51(4) July 1954, do American Institute for Research e da Universidade de Pittsburgh. 
42 - Brookfield SD. Developing critical thinkers - challenging adults to explore alternative ways of thinking and acting. San Francisco: Jossey - Bass; 1988.

43 - Smith A, Russel J. Using critical learning incidents in nurse education. Nurse Educ Today 1991; 11(4): 284-91.

44 - Benner P. From novice to expert. Addison-Wesley Publishing Company. California; 1984.

45 - Brown L. The experience of care: patient perspectives. Top clin nurs 1986; 8(2): 56-62.

46 - Polit DF, Hungler BP. Fundamentos de pesquisa em enfermagem. 3ed. Porto Alegre: Artes Médicas; 1995.

47 - Bardin L. Análise de conteúdo. Lisboa: Edições 70; 1977.

48 - Ide CAC, De Domenico EBL, Gatto MAF. O incidente crítico como método de avaliação da competência clínica: um estudo com alunos da graduação em enfermagem. 2002 [no prelo].

49 - Brasil. Lei n. 9394 de 20 de dezembro de 1996. Lei de Diretrizes e Base para Educação Nacional. Diário Oficial da República Federativa do Brasil, Brasília, 23 dez. 1996.

50 - Universidade Estadual Paulista - Faculdade de Medicina. Projeto PolíticoPedagógico do Curso de Graduação em Enfermagem da Faculdade de Medicina de Botucatu: reestruturação, elaborado, pela Coordenação do Curso de Graduação em Enfermagem-FMB-UNESP. Botucatu: UNESP, 2003. 
51 - Conselho Nacional de Saúde. Resolução n. 196, de 10 de outubro de 1996. Diretrizes e normas regulamentadoras de pesquisas envolvendo seres humanos. Bioética, 1996; 4(suppl 2): 15-25.

52 - Mynaio MCS. O desafio do conhecimento: pesquisa qualitativa em saúde. 5 ed. São Paulo: Hucitec - Abrasco; 1998.

53 - Ide CAC. A Coordenação do processo de cuidar. In: Ide CAC, De Domenico E B L. Ensinando e aprendendo um novo estilo de cuidar. São Paulo: Atheneu; 2001 p. $153-71$.

54 - Goffman E. Manicômios, prisões e conventos. São Paulo: Perspectiva; 1974.

55 - Martins RCT. A inserção do recém formado no mundo do trabalho: os significados dessa experiência na enfermagem. [tese] São Paulo(SP): Escola de Enfermagem da USP; 1999.

56 - Lunardi Filho WD. Prazer e sofrimento no trabalho: contribuições à organização do processo de trabalho da enfermagem. Rev Bras Enferm 1997; 50(1): 77-92.

57 - Magalhães LMT. O ensino superior em enfermagem e o desafio da mudança: os referenciais de um novo processo de formação [tese]. São Paulo (SP). Escola de Enfermagem da USP; 2000.

58 - Moura MLPA, Sazano SDT, Cerqueira LT de, Viana LAC, Zecchinato MC. A força de trabalho em enfermagem no Estado de São Paulo. São Paulo: COREN/ABEn; 1996. 
59 - Fundação para o Vestibular da Universidade Estadual Paulista. Relatório do Vestibular 1998, Coordenação do Vestibular - Carlos Felício Vanni e Fernando Dagnoni Prado. São Paulo: VUNESP; 1998. p. 61.

60 - Fundação para o Vestibular da Universidade Estadual Paulista. Relatório do Vestibular 1999. Coordenação do Vestibular - Fernando Dagnoni Prado. São Paulo: VUNESP; 1999. p. 72.

61 - Coordenação do Curso de Graduação em Enfermagem. FMB - UNESP. Relatório de Avaliação do Ensino da Graduação em Enfermagem. Botucatu: UNESP-FMB; 2003.

62 - Brasil. Ministério da Educação. Instituto Nacional de Estudos e Pesquisas Educacionais. Provão 2002: relatório-síntese, resumo técnico / Brasília: O Instituto; 2002. 69p.

63 - Aikawa, R. Aumente sua bagagem. Folha de São Paulo 25 nov 2003; Sinapse.

64 - Laplance, J. Vocabulário da psicanálise - Laplanche e Pontalis. São Paulo: Martins Fontes; 1992.

65 - Ferreira ABH. Novo dicionário da língua portuguesa. Rio de Janeiro: Nova Fronteira; 1986.

66 - Falcone EMO. A avaliação de um programa de treinamento de empatia com universitário [tese]. São Paulo (SP): Instituto de Psicologia da USP; 1998. 
67 - De Domenico EBL. Projeto de formandos em enfermagem: representações do vir a ser profissional [Mestrado]. São Paulo(SP): Escola de Enfermagem da USP; 1999.

68 - Ide CAC, Chaves EC. Fundamentos para a construção de uma teoria de ensino/apresentado no curso de atualização "O ensino do processo de cuidar do adulto: perspectivas para a questão". São Paulo, 1992. Mimeografado.

69 - Ide CAC, Chaves, EC. Educação em enfermagem: o movimento constituinte da sua identidade. Rev Esc Enferm USP 1996; 30(3): 371-9.

70 - Ângelo M. Educação em enfermagem. Rev Esc Enferm USP 1994; 28(1): 11-4.

71 - Püschel VA de A. A enfermagem e o futuro: as representações que conformam um novo esboço de profissão [Dissertação]. São Paulo(SP): Escola de Enfermagem da USP; 1999.

72 - Bagnato MH. Formação crítica dos profissionais da área de enfermagem. Texto Contexto Enferm 1999; 8 (1): 31-41.

73 - Geib LTC, Migott AMB, Carvalho RMA, Mocinho RR. Os rituais de poder na educação formal do enfermeiro. Texto Contexto Enferm 1999; 8(1): 80-92.

74 - Bourdie P, Passeron JC. A reprodução: elementos para uma teoria do sistema de ensino. Rio de Janeiro: Francisco Alves; 1996.

74 - Ern E, Backes VMS, Currículo: aspectos que educadores e educandos da enfermagem devem conhecer. Texto Contexto Enferm 1999; 8(1): 43-52. 
75 - Machado NJ. A universidade e a organização do conhecimento: a rede, o tácito, a dádiva. Estudos Avançados 2001; 15(42): 333-52.

76 - Vygotsky LS. A formação social da mente. 4 ed. São Paulo: Martins Fontes; 1991. 
ANEXOS 


\section{- ANEXO A - \\ TERMO DE CONSENTIMENTO LIVRE E ESCLARECIDO \\ (Resolução 196/96 do Ministério da Saúde) ${ }^{(51)}$}

$\mathrm{Eu}$ $\mathrm{RG} \mathrm{n}^{\circ}$

domiciliado (a) na Rua $\mathrm{n}^{\mathrm{O}}$

na cidade , fone:

"Competência Clínica do Graduando de Enfermagem: bases dessa construção", cujo objetivo é identificar e mapear as competências pertinentes a ação clínica dos graduandos de enfermagem.

Declaro que fui esclarecido (a) quanto ao (s):

1 - Objetivo do estudo já explicitado.

2 - A garantia de receber esclarecimento a qualquer dúvida relacionada com a pesquisa;

3 - A liberdade de retirar meu consentimento a qualquer momento e deixar de participar do estudo; sem qualquer repercussão no meu aprendizado.

4 - A segurança de que não serei identificado e que será mantido o caráter confidencial das informações fornecidas.

5 - Que a pesquisadora esteja disponível para os esclarecimentos que eu julgar necessário e em caso de não me sentir atendido (a), poderei entrar em contato com a Coordenadora do Curso de Graduação em Enfermagem - UNESP Botucatu.

Botucatu, de de 200

Assinatura do Participante do Estudo, declarando que após ter recebido todas as informações referentes à pesquisa, concorda em participar da população em estudo.

Magda Cristina Queiroz Dell'Acqua*

COREn-SP: 35621

Pesquisadora

*Endereço: Rua Daniel Zacarias, 803 - Jd. Paraíso - Botucatu/SP.

Tel.: (14) 3815.4938

Curso de Graduação em Enfermagem da FMB-UNESP.

Tel.: (14) 3811.6070

E-mail: mqueiroz@fmb.unesp.br 


\section{- ANEXO B -}

\section{INSTRUMENTO DE COLETA DE DADOS}

Estamos desenvolvendo um estudo cujo objetivo é identificar e mapear as competências pertinentes a ação clínica dos graduandos de enfermagem.

Este instrumento é composto por 3 partes com objetivos distintos.

I - Caracterização do perfil do aluno.

II - Percepção do aluno acerca das competências ensinadas e desenvolvidas no decorrer da graduação.

III - A descrição de uma situação clínica vivida pelo aluno.

O estudo refere-se ao meu doutorado, sendo que a sua participação será importante para eu compor a minha tese, e com isso, possibilitar a identificação de elementos que poderão ser utilizados para repensar a abordagem de ensino, na perspectiva de construção de competência clínica.

Gostaria de contar com sua preciosa colaboração, respondendo ao questionário abaixo.

Muito obrigada.

Magda. 


\section{- ANEXO B -}

I - IDENTIFICAÇÃO: Caracterização do Aluno

NOME:

1. Idade anos meses

2. Sexo:

( ) masculino

( ) feminino

3. Trajetória escolar antes da graduação

( ) 1ํograu em escola pública

( ) $1^{\circ}$ grau em escola particular

( ) 2o grau em escola pública

( ) $2^{\circ}$ grau em escola particular

( ) não fiz cursinho

( ) fiz cursinho por

( ) vestibular com anos ingressar ano (s) de prova (s) prestada (s) antes de

4. Trajetória durante a graduação

( ) tempo de graduação em anos:

( ) se realizou trabalhos de pesquisa, relate os temas e o número de estudos: $\mathrm{n}$ ㅇ: Temas:

( ) se participou de eventos extracurriculares, como congressos, dentre outros: quantos: na (s) área (s):

( ) se foi monitor, em quais disciplinas, por quanto tempo:

( ) se participou de projetos de extensão: na (s) área (s):

( ) se participou de estágios extracurriculares: na (s) área (s):

( ) se foi bolsista, tipo de órgão que fomentou:
( ) PAE
( ) CAPES
( ) $\mathrm{CNPq}$
( ) FAPESP ( ) OUTROS 
( ) se participou como membro em conselhos:

quais: na (s) área (s):

( ) outras informações relevantes de sua participação durante a graduação que deseje registrar:

5. Caracterize seus hábitos de vida.

6. Faça uma auto-descrição tentando retratar-se de maneira fiel. 
7. Seu projeto profissional: descreva o que pretende fazer após a graduação. 


\section{- ANEXO B -}

\section{II - PERCEPÇÃO DISCENTE ACERCA DAS COMPETÊNCIAS CLÍNICAS DESENVOLVIDAS PELA GRADUAÇÃO}

Entende-se por Competência Clínica:

Competência Clínica compreende mais que a habilidade de tomar decisões consiste na habilidade de unir conhecimento formal e experiência clínica, além de representar um processo de desenvolvimento cognitivo, psicomotor e afetivo ${ }^{(34-36)}$.

Das expressões de competências da ordem cognitiva, psicomotora e afetiva derivam possibilidades como: competência técnica ou procedimental; científica ou conceitual, correlacionando a teoria à prática; comportamental, vinculada às interações e abordagem interpessoal; ética; política; educativa; investigativa; dentre outras.

COMPETÊNCIAS CLÍNICAS, vão além da memorização precisa e de uma lembrança oportuna de teorias pertinentes. Nas situações atípicas é exigido fazer relacionamentos, interpretações, interpelações, inferências, invenções, em suma, complexas operações mentais cuja orquestração só pode construir-se ao vivo, em função tanto de seu saber e de sua perícia quanto de sua visão da situação ${ }^{(14)}$.

1. Considerando esse referencial frente às suas experiências de aprendizagem, descreva o que você entende por Competência Clínica. 
2. Como essas competências clínicas foram sendo ensinadas nas diferentes disciplinas, tais como:

- Introdução à Enfermagem:

- Fundamentos de Enfermagem:

- Enfermagem Médico-Cirúrgica:

- Enfermagem em Centro-Cirúrgico:

- Enfermagem em Doenças Transmissíveis:

- Enfermagem Pediátrica:

- Enfermagem Ginecológica, Obstétrica e Neonatal

- Enfermagem Psiquiátrica

- Enfermagem Preventiva e Comunitária: 
3. Como foi o aprendizado das competências clínicas nas diferentes disciplinas relacionadas? Quais as facilidades e as dificuldades que você encontrou? Exemplifique. 
4. Que relações você estabelece entre as competências clínicas desenvolvidas, ensinadas na graduação e as presentes e percebidas por você na prática do enfermeiro assistencial no campo. 


\section{- ANEXO C - \\ "O INCIDENTE CRÍTICO"}

\section{III - A FORMULAÇÃO DE INCIDENTE COMO EXPRESSÃO DE COMPETÊNCIA CLÍNICA \\ A descrição de uma situação clínica vivida pelo aluno}

\section{INSTRUÇÕES PARA OS ALUNOS:}

Este instrumento tem por finalidade obter a descrição detalhada de um incidente crítico vivenciado por você na prática clínica correspondente à sua experiência em campos de estágios, no transcorrer das disciplinas com o foco assistencial/clínico como: Introdução à Enfermagem, Fundamentos de Enfermagem; Enfermagem Médico-Cirúrgica, Enfermagem em Doenças Transmissíveis, Enfermagem em Centro Cirúrgico, Enfermagem Pediátrica, Enfermagem Ginecológica, Obstétrica e Neonatal, Enfermagem Psiquiátrica e Enfermagem Preventiva e Comunitária. Suas descrições serão analisadas buscando-se mapear as competências pertinentes à sua ação clínica. A seguir estão algumas definições e orientações para você elaborar os seus relatos.

Agradeço imensamente a sua colaboração. 


\section{A - O que constitui um Incidente Crítico}

Definição: Incidente crítico compreende qualquer incidente ou situação que tenha causado forte impacto sobre você. Pode ter sido durante a interação com algum paciente, familiares, colegas, professor ou com algum membro da equipe de saúde.

Uma situação na qual sua intervenção direta ou indireta (auxiliando o professor ou outro profissional) fez a diferença na evolução do paciente, situação essa que pode ter tido uma resolução positiva ou negativa.

Por exemplo, você poderá registrar:

- uma situação que evoluiu excepcionalmente bem.

- uma situação na qual houve falhas, como coisas não planejadas.

- uma situação inédita ou típica.

- uma situação vista por você como um exemplo para a enfermagem.

- uma situação particularmente trabalhosa.

Dos exemplos acima você poderá associar situações vividas por você.

\section{B - Como registrar o incidente crítico: descreva em detalhes o Incidente Crítico (situação) da sua prática de enfermagem (como aluna), definida e delineada no item A:}

$B_{1}$ - O contexto da situação, como: período do dia, profissionais envolvidos, condições de trabalho, disciplina que estava cursando, unidade ou enfermaria onde ocorreu a situação, ano da graduação que estava cursando.

$\mathrm{B}_{2}$ - Uma detalhada descrição do que aconteceu durante o processo de ensinoaprendizagem que influenciaram na experiência do incidente crítico (situação).

$\mathrm{B}_{3}-$ Por que o incidente foi crítico para você?

$\mathrm{B}_{4}$ - Como você se comportou nessa situação?

$\mathrm{B}_{5}-\mathrm{O}$ que você sentiu durante e após o incidente (situação)?

$\mathrm{B}_{6}-\mathrm{O}$ que você avalia como tendo sido mais trabalhoso na situação?

$\mathrm{B}_{7}-\mathrm{O}$ que você avalia como tendo gerado maior satisfação na situação? 
$\mathbf{B}_{1}$ - O contexto da situação, como: período do dia, profissionais envolvidos, condições de trabalho, disciplina que estava cursando, unidade ou enfermaria onde ocorreu a situação, ano da graduação que estava cursando. 
$\mathbf{B}_{\mathbf{2}}$ - Uma detalhada descrição do que aconteceu durante o processo de ensino-aprendizagem que influenciaram na experiência do incidente crítico (situação). 
$\mathbf{B}_{3}$ - Por que o incidente foi crítico para você? 
$\mathbf{B}_{4}$ - Como você se comportou nessa situação? 
$\mathbf{B}_{5}$ - O que você sentiu durante e após o incidente (situação)? 
$\mathbf{B}_{6}-\mathrm{O}$ que você avalia como tendo sido mais trabalhoso na situação? 
$\mathbf{B}_{7}-\mathrm{O}$ que você avalia como tendo gerado maior satisfação na situação? 


\author{
- ANEXO D - \\ "PARECER DO COMITÊ DE ÉTICA EM PESQUISA"
}


As figuras foram extraídas do livro: "O livro das virtudes para crianças" de Willian J. Bennet. 


\section{Autorização para reprodução}

Autorizo a reprodução deste trabalho.

São Paulo, 17 de fevereiro de 2004.

MAGDA CRISTINA QUEIROZ DELL'ACQUA 